Особенности ведения коморбидных пациентов в период пандемии новой коронавирусной инфекции (COVID-19). Национальный Консенсус 2020

\author{
Гриневич В.Б., Губонина И.В., Аощицин В.А., Котовская Ю.В.”\#, Кравчук Ю.А.\#\#, \\ Педь В.И., Сас Е.И., Сыров А.В., Тарасов А.В., Тарзиманова А.И.”\#, Ткачёва О.Н.”, \\ Трухан А.И.
}

Национальная медицинская Ассоциация по изучению Сочетанных Заболеваний (НАСЗ); Профессиональный фонд содействия развитию медицины “ПРОФМЕАФОРУМ”. Москва, Россия

Научные рецензенты: Академик РАН, профессор Оганов Р.Г. (Москва), Академик РАН, профессор Маев И. В. (Москва), профессор Шальнова С.А. (Москва).

Пандемия новой коронавирусной инфекции (COVID19), распространяемая вирусом SARS-CoV-2, стала вызовом системам здравоохранения всех стран мира. Коморбидные пациенты являются наиболее уязвимой группой, у которой риск неблагоприятных исходов особенно высок. Проблема ведения коморбидных пациентов в условиях пандемии требует комплексного подхода, направленного как на оптимальное ведение коморбидных состояний у пациентов, которые находятся в условиях самоизоляции, в условиях вынужденных ограничений посещения медицинских учреждений, так и на ведение коморбидных состояний у пациентов, заболевших COVID-19. Представляемый вашему вниманию консенсус охватывает эти два аспекта ведения пациентов с заболеваниями сердечно-сосудистой системы, сахарным диабетом, хронической обструктивной болезнью легких, заболеваниями желудочно-кишечного тракта, а также обращается к полиорганным осложнениям COVID-19.

Ключевые слова: COVID-19, коморбидность, проницаемость барьера слизистой оболочки, заболевания сердечно-сосудистой систе- мы, хроническая обструктивная болезнь легких, сахарный диабет, болезни органов пищеварения.

\section{Отношения и деятельность: нет.}

\# - Научный руководитель проекта.

\# - Научные координаторы проекта.

Поступила 15/06-2020

Принята к публикации 29/06-2020

(cc) BY 4.0

Для цитирования: Гриневич В.Б., Губонина И.В., Дощицин В.Л., Котовская Ю.В., Кравчук Ю.А., ПедьВ.И., Сас Е.И., Сыров А.В., Тарасов А.В., Тарзиманова А.И., Ткачёва О.Н., Трухан Д.И. Особенности ведения коморбидных пациентов в период пандемии новой коронавирусной инфекции (COVID-19). Национальный Консенсус 2020. Кардиоваскулярная терапия и профилактика. 2020;19(4):2630. doi:10.15829/1728-8800-2020-2630

\title{
Management of patients with comorbidity during novel coronavirus (COVID-19) pandemic.
} National Consensus Statement 2020

Grinevich V. B., Gubonina I. V., Doshchitsin V.L., Kotovskaya Yu. V.”, Kravchuk Yu. A.\#, Ped V. I., Sas E. I., Syrov A. V., Tarasov A. V., Tarzimanova A.I.", Tkacheva O. N.", Trukhan D.I.

National Medical Association for the Study of the Multimorbidity; Fund "PROFMEDFORUM". Moscow, Russia

Peer reviewers: Oganov R. G. (Moscow), Academician of RAS, Professor; Mayev I. V. (Moscow), Academician of RAS, Professor; Shalnova S. A. (Moscow), Professor.

The pandemic of the novel coronavirus infection (COVID-19), caused by SARS-CoV-2, has become a challenge to healthcare systems in all countries of the world. Patients with comorbidity are the most vulner- able group with the high risk of adverse outcomes. The problem of managing these patients in context of a pandemic requires a comprehensive approach aimed both at the optimal management in self-iso-

*Автор, ответственный за переписку (Corresponding author):

e-mail: tarzimanova@mail.ru

[Гриневич В. Б. - д.м.н., профессор, зав. 2 кафедрой (терапии усовершенствования врачей), ФГБВоу Во Военно-медицинская Академия им. С. М. Кирова Министерства обороны РФ, Санкт-Петербург, ORCID: 0000-0002-1095-8787, Губонина И. В. - к.м.н., доцент 2-й кафедры (терапии усовершенствования врачей), ФГБВоУ ВО Военно-медицинская Академия им. С. М. Кирова Министерства обороны PФ, Санкт-Петербург, ORCID: 0000-0002-6302-7767, Дощицин В. Л. - д.м.н., профессор кафедры кардиологии, ФГАОУ ВО РНИМУ им. Н. И. Пирогова Минздрава, Москва, ОRCID: 0000-0001-8874-4108, Котовская Ю. В. - Д. М.Н., профессор, заместитель директора по научной работе ОСП РГНКЦ ФГАОУ ВО РНИМУ им. Н. И. Пирогова Минздрава, Москва, ОRСІD: 0000-0002-1628-5093, Кравчук Ю. А. д.м.н., профессор 2 кафедры (терапии усовершенствования врачей), ФГБВоУ ВО Военно-медицинская Академия им. С. М. Кирова Министерства обороны РФ, Санкт-Петербург, ОRCID: 0000-0001-

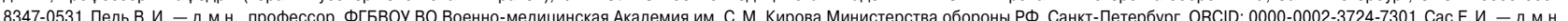
834Ко К002-2536-5781, Тарасов А. В. - д.м.н., врач кардиолог-аритмолог; зав. отделением хирургического лечения сложных нарушений ритма сердца, Национальный медицинский исследовательский центр

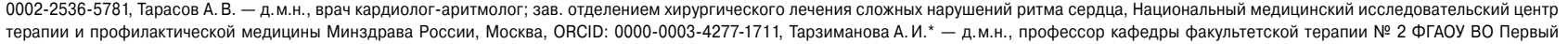
МГМУ им. И. М. Сеченова Минздрава России (Сеченовский Университет), Москва, ORCID: 0000-0001-9536-8307, Ткачева О. Н. - Д. м.н., профессор, директор ОСП Российский геронтологический научно-клинический центр, ФГАОУ ВО РНИМУ им. Н. И. Пирогова Минздрава России, главный внештатный гериатр Минздрава России, Москва, ОRCID: 0000-0002-4193-688X, Трухан Д. И. - д. М. .., профессор кафедры поликлинической терапии и внутренних болезней, ФГБОУ ВО Омский государственный Университет Минздрава России, Омск, ORCID: 0000-0002-1597-1876]. 
lated patients not visiting medical facilities, and management of comorbidities in patients with COVID-19. The presented consensus covers these two aspects of managing patients with cardiovascular disease, diabetes, chronic obstructive pulmonary disease, gastrointestinal disease, and also pay attention to the multiple organ complications of COVID-19.

Key words: COVID-19, comorbidity, permeability of mucosa, cardiovascular diseases, chronic obstructive pulmonary disease, diabetes, gastrointestinal diseases.

\section{Relationships and Activities: none.}

\#- Research supervisor

\#- Research coordinators

Grinevich V.B. ORCID: 0000-0002-1095-8787, Gubonina I.V. ORCID: 0000-0002-6302-7767, Doshchitsin V.L., Kotovskaya Yu.V. ORCID: 0000-0002-1628-5093, Kravchuk Yu.A. ORCID: 0000-0001-8347-0531,
Ped V.I. ORCID: 0000-0002-3724-7301, Sas E.I. ORCID: 0000-00028445-8363, Syrov A.V. ORCID: 0000-0002-2536-5781, Tarasov A.V. ORCID: 0000-0003-4277-1711, Tarzimanova A. I.* ORCID: 0000-00019536-8307, Tkacheva O. N. ORCID: 0000-0002-4193-688X, Trukhan D. I. ORCID: 0000-0002-1597-1876.

\section{*Corresponding author: tarzimanova@mail.ru}

Received: 01/06-2020

Accepted: 04/06-2020

For citation: Grinevich V.B., Gubonina I. V., Doshchitsin V.L., Kotovskaya Yu. V., Kravchuk Yu.A., Ped V.I., Sas E. I., Syrov A. V., Tarasov A. V., Tarzimanova A. I., Tkacheva O. N., Trukhan D. I. Management of patients with comorbidity during novel coronavirus (COVID-19) pandemic. National Consensus Statement 2020. Cardiovascular Therapy and Prevention. 2020;19(4):2630. (In Russ.) doi:10.15829/1728-88002020-2630

АГ - артериальная гипертензия, АД - артериальное давление, АК - блокаторы кальциевых каналов, АЛТ - аланинаминотрансфераза, АПФ2 - ангиотензинпревращающий фермент 2 типа, АСК - ацетилсалициловая кислота, ББ - бета-адреноблокаторы, БК - болезнь Крона, БРА - блокаторы рецепторов ангиотензина ІІ, ВЗК - воспалительные заболевания кишечника, ГКС - глюкокортикостероиды, ГЭРБ - гастроэзофагеальная рефлюксная болезнь, ДИ - доверительный интервал, ЖКТ - желудочно-кишечный тракт, ЖТ - желудочковая тахикардия, иАПФ - ингибиторы ангиотензинпревращающего фермента, ИБС - ишемическая болезнь сердца, ИМ - инфаркт миокарда, ИПП - ингибиторы протонной помпы, КТ - компьютерная томография, КФК-МВ - креатинфосфокиназа-МВ, ЛЖ - левый желудочек, МРТ - магнитно-резонансная томография, НАЖБП - неалкогольная жировая болезнь печени, НАСГ - неалкогольный стеатогепатит, НМГ - низкомолекулярный гепарин, НПВП - нестероидные противовоспалительные препараты, НФГ - нефракционированного гепарина, ОКС - острый коронарный синдром, ОКСбпST - острый коронарный синдром без подьема сегмента ST, ОКСпST острый коронарный синдром с подъемом сегмента ST, OP - отношение рисков, ОРДС - острый респираторный дистресс-синдром, РАAC - ренин-ангиотензин-альдостероновая система, РГА Российская гастроэнтерологическая ассоциация, РНК - рибонуклеиновая кислота, РФ - Российская Федерация, СД - сахарный диабет, СН - сердечная недостаточность, СО - слизистая оболочка, СРК - Синдом раздан

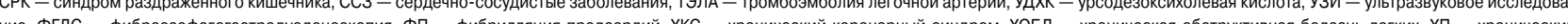
ние, ФГДС - фиброэзофагогастродуоденоскопия, ФП - фибрилляция предсердий, ХКС - хронический коронарный синдром, ХОБЛ - хроническая обструктивная болезнь легких, ХП - хронический
панкреатит, ХСН - хроническая сердечная недостаточность, ЧКВ - чрескожное коронарное вмешательство, ЭКГ - электрокардиография, ЭхоКГ - эхокардиография, ЯБ - язвенная болезнь, ЯК - язвенпанкреатит, ХCH - хроническая сердечная недостаточность, ЧКВ - чрескожное коронарное вмешательство, ЭКГ - электрокардиография,
ный колит, 5-ACK - 5-аминосалициловая кислота, COVID-19 - новая коронавирусная инфекция, ESC - European Society of Cardiology.

\section{Содержание}

Введение.

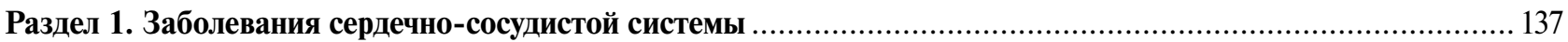

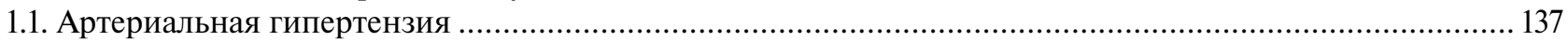

1.2. Хронический коронарный синдром ........................................................................ 138

1.3. Острый коронарный синдром (острый инфаркт миокарда и нестабильная стенокардия) ................. 139

1.4. Нарушение ритма сердца ...................................................................................... 141

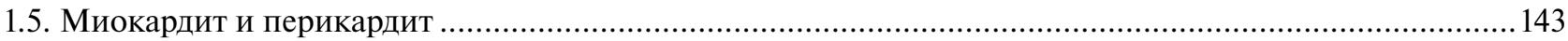

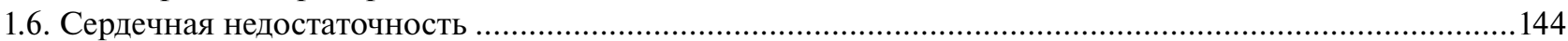

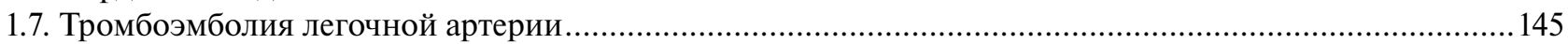

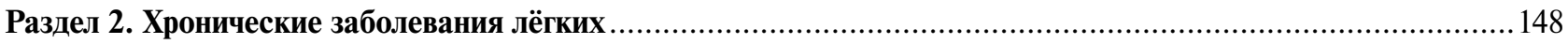

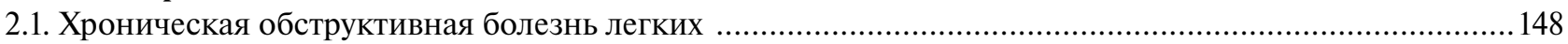

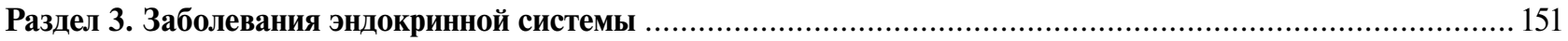

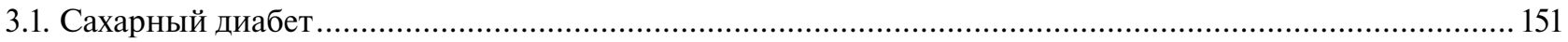

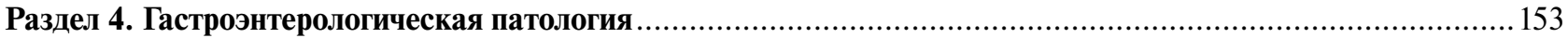

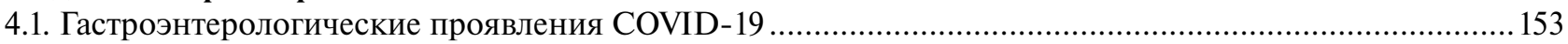

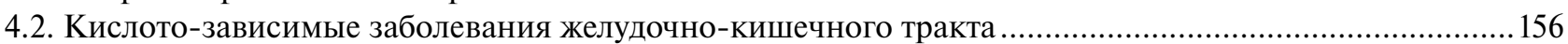

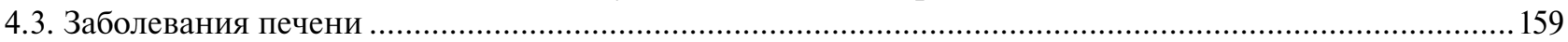

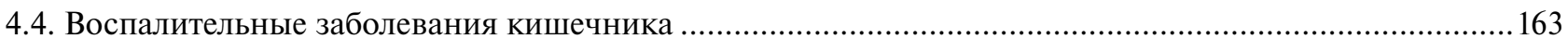

4.5. Синдром раздражённого кишечника ....................................................................................

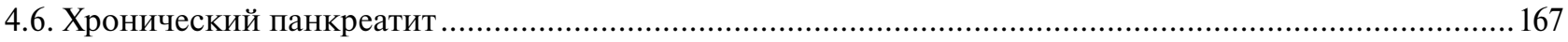




\section{Введение}

Пандемия новой коронавирусной инфекции (COVID-19), распространяемая вирусом SARS$\mathrm{CoV}-2$, является вызовом системам здравоохранения всех стран мира. Наиболее частым проявлением COVID-19 является поражение дыхательной системы. Однако для этого заболевания характерна высокая активность воспаления и тромботические осложнения, приводящие к полиорганным поражениям. Ведение пациента с COVID-19 подразумевает не только лечение пневмонии и дыхательной недостаточности, но и своевременное распознавание и лечение поражения других органов-мишеней.

Анализ факторов, связанных с тяжелым течением и неблагоприятным прогнозом COVID-19, указывает на важную роль коморбидной патологии. K состояниям, которые ассоциированы с неблагоприятным прогнозом, относят сердечно-сосудистые заболевания (СС3) (артериальную гипертензию (АГ), ишемическую болезнь сердца (ИБС), хроническую сердечную недостаточность (ХСН), фибрилляцию предсердий (ФП)), сахарный диабет (СД), хроническую обструктивную болезнь легких (ХОБЛ), хронические воспалительные заболевания кишечника (В3К), заболевания печени. Это означает, что профилактические меры в период пандемии COVID19 должны складываться как из мероприятий по предотвращению инфицирования, так и мероприятий, направленных на оптимальный контроль коморбидных состояний.

В настоящее время нет универсальных рекомендаций по лечению COVID-19, лечение основывается на представлениях о патогенезе заболевания и носит синдромный подход. Многие лекарственные препараты и их комбинации применяются offlabel. В таких условиях особое значение имеет безопасность лекарственной терапии, учет рисков возможных межлекарственных взаимодействий, что особенно актуально у коморбидных пациентов.

Цель данного документа - предоставить врачам практические рекомендации и важную информацию, которая может быть полезна при ведении всего спектра коморбидных пациентов в условиях пандемии COVID-19 - как неинфицированных, так и переносящих COVID-19. Обобщена информация по лечению хронических и острых заболеваний сердечно-сосудистой системы, ХОБЛ, СД, гастроэнтерологической патологии.

\section{Раздел 1. Заболевания сердечно-сосудистой системы}

Пандемия COVID-19 представляет особую угрозу для пациентов с заболеваниями сердечно-сосудистой системы. Возникновение COVID-19 сопровождается высоким риском тромботических осложнений, острого коронарного синдрома (ОКС), нарушений сердечного ритма, что значительно ухуд- шает прогноз пациентов. Смертность у больных c COVID-19 и сердечно-сосудистой патологией существенно выше, чем у пациентов без заболеваний сердца.

Кроме того, известно, что некоторые лекарственные препараты, использующиеся при лечении COVID-19, обладают нежелательными эффектами в отношении сердечно-сосудистой системы, что проявляется целым рядом осложнений.

В настоящее время появляются новые данные об особенностях течения COVID-19 при заболеваниях сердечно-сосудистой системы, внедряются современные методы профилактики и лечения данной инфекции, что нашло отражение в представленном документе.

\section{1. Артериальная гипертензия}

АГ диагностируется более чем у $30 \%$ пациентов с COVID-19 [1]. Высокая распространенность АГ при COVID-19 не подразумевает причинную связь между этими заболеваниями, т.к. наиболее часто АГ страдают люди пожилого возраста и именно они подвергаются высокому риску инфицирования вирусом SARS-CoV-2. Наличие АГ ухудшает прогноз пациентов с COVID-19 и повышает риск летального исхода более чем в 2 раза [2].

Факторами риска развития неблагоприятного прогноза у больных АГ с COVID-19 считают пожилой возраст, нарушения иммунной системы, обсуждается роль повышения ангиотензинпревращающего фермента 2 (АПФ2) [3].

Предметом дискуссий остается вопрос о влиянии приема ингибиторов ангиотензинпревращающего фермента (иАПФ) или блокаторов рецепторов ангиотензина II (БРА) на увеличение риска инфицирования и более тяжелого течения COVID-19. Эти выводы были сделаны на основании первоначальных сообщений из Китая и последующих доказательств того, что наличие коморбидных состояний, таких как АГ, ХСН, ИБС, СД, заболевания почек и возраст старше 70 лет связано с более тяжелым течением и повышенным риском смерти у госпитализированных пациентов, инфицированных COVID-19 [1].

Предположение о неблагоприятных эффектах приема иАПФ или БРА возникло из-за того, что вирус связывается с ферментом АПФ2 для проникновения в клетки, и результатов небольших работ на животных, показавших увеличение активности АПФ2 рецепторов коры почек крыс на фоне лечения иАПФ лизиноприлом и БРА лозартаном [4], в то время как на людях эффект компенсаторного повышения АПФ2 не показан. Эта информация послужила основой предположения о возможном неблагоприятном эффекте иАПФ и БРА в контексте пандемии COVID-19. Однако в настоящий момент отсутствуют данные о повышенной воспри- 
имчивости или более тяжелом течении COVID-19 у пациентов, получающих иАПФ или БРА [5]. Ряд авторов считают, что имеются косвенные данные о возможном протективном действии этих препаратов при COVID-19 [6].

Коррекция АГ у больных с COVID-19 проводится исходя из общих клинических рекомендаций. Основой антигипертензивной терапии являются 5 классов препаратов: иАПФ, БРА, бета-адреноблокаторы (ББ), блокаторы кальциевых каналов (АК) и диуретики [7]. Все группы антигипертензивных препаратов могут применяться для лечения АГ при COVID-19. Экспертами Европейского общества кардиологов опубликовано заявление о том, что данных о неблагоприятных эффектах иАПФ и БРА на течение COVID-19 нет, их прием рекомендуется продолжать [6].

Многочисленными рандомизированными клиническими исследованиями показано, что монотерапия эффективно снижает артериальное давление (АД) лишь у ограниченного числа пациентов АГ, большинству пациентов для контроля АД требуется комбинация как минимум из двух препаратов. Все преимущества комбинированной терапии присущи только рациональным комбинациям антигипертензивных препаратов. К ним относятся: иАПФ + диуретик; БРА + диуретик; иАПФ + АК; БРА + АК, дигидропиридиновый АК + ББ, АК + диуретик, ББ + диуретик [7]. Принципы комбинированной терапии для лечения АГ сохраняются и в условиях пандемии COVID-19.

Учитывая, что наиболее тяжелое течение и высокий риск неблагоприятного исхода COVID19 отмечаются у пациентов пожилого возраста, течение и лечение АГ в этой группе имеет свои особенности. Альтернативой препаратам, влияющих на ренин-ангиотензин-альдостероновую систему (РААС), при лечении пожилых пациентов с систолической АГ могут быть АК и диуретики. В современных рекомендациях по лечению пациентов с коморбидной патологией отмечены результаты исследования Syst-Eur, показавшие высокую антигипертензивную эффективность нитрендипина и его церебропротективные свойства [8]. Среди диуретических препаратов, применяющихся для лечения АГ, наиболее высокой эффективностью обладает индапамид. По сравнению с гидрохлоротиазидом и хлорталидоном индапамид характеризуется метаболической нейтральностью, в меньшей степени влияет на уровень калия и магния (это особенно важно с точки зрения безопасности применения гидроксихлорохина, удлиняющего интервал QTc), имеет более выраженные органопротективные свойства, поэтому его назначение более предпочтительно [9].

Следует отметить, что назначение противовирусной терапии комбинацией лопинавира и рито- навира имеет ограничения в контексте антигипертензивной терапии у пациентов с COVID-19: данная комбинация может усиливать антигипертензивный эффект некоторых препаратов и в ряде случаев требует коррекции их дозы; применение эплеренона противопоказано при назначении комбинированной противовирусной терапии [6].

Резюме:
1. АГ является одним из наиболее распространенных заболева-
ний сердечно-сосудистой системы при COVID-19. Наличие
АГ ухудшает прогноз пациентов с COVID-19 и повышает риск
летального исхода более чем в 2 раза.
2. Коррекция АГ у больных COVID-19 проводится исходя
из общих клинических рекомендаций.
3. Назначение противовирусной терапии с комбинацией лопи-
навира и ритонавира имеет некоторые ограничения в выборе
антигипертензивной терапии, может усиливать антигипертен-
зивный эффект некоторых препаратов и в ряде случаев требует
коррекции их дозы.

\section{2. Хронический коронарный синдром}

Пациенты с хронической ИБС составляют группу риска тяжелого течения COVID-19 и смерти, а также обострения ранее стабильного течения ИБС [6]. Пожилые пациенты с сопутствующими состояниями чаще инфицируются SARS-CoV-2, в особенности при наличии АГ, ИБС и СД [10]. В настоящее время остается неясным, сохраняется ли риск сердечно-сосудистых осложнений в отдаленном периоде заболевания [5].

В 2019г опубликованы новые европейские рекомендации по диагностике и лечению хронических коронарных синдромов. Применяемый ранее термин стабильная ИБС был заменен на хронический коронарный синдром (ХКС) [11].

Выделено 6 клинических сценариев ХКС:

1. Пациенты с подозрением на ИБС со стабильными симптомами стенокардии и/или одышки;

2. Пациенты с вновь развившейся сердечной недостаточностью $(\mathrm{CH})$ или систолической дисфункцией левого желудочка (ЛЖ) и подозрением на ИБС;

3. Бессимптомные или симптомные стабильные пациенты $<1$ года после ОКС или реваскуляризации;

4. Бессимптомные пациенты и пациенты с симптомами $>1$ года после установки диагноза или реваскуляризации;

5. Пациенты, имеющие стенокардию, с возможным вазоспастическим или микрососудистым патогенезом болезни;

6. Бессимптомные пациенты, у которых ИБС была обнаружена при скрининге.

Данные варианты ХКС включают пациентов с различным риском сердечно-сосудистых событий, причем любой клинический сценарий может закончиться дестабилизацией в виде развития ОКС, что следует учитывать во время пандемии COVID-19. 
У пациентов с XKC лечение COVID-19 проводится по общим принципам. Бессимптомное и легкое течение не требует медикаментозной терапии за исключением жаропонижающих средств. Препаратом выбора является парацетамол в дозе 1000 мг не более 4-х раз/сут. [12, 13]. Важным компонентом лечения является выполнение дыхательных упражнений и отдых в положении на животе. Не рекомендуется спать в положении на спине [13, 14]. Обязателен контроль АД и пульса.

Рекомендуется продолжить прием препаратов, назначенных в соответствии с клиническими рекомендациями по ведению пациентов с ХКС, с особым вниманием к терапии, стабилизирующей атеросклеротическую бляшку (статины, аспирин, блокаторы РААС, ББ). В настоящее время нет доказательств рисков, ассоциированных с приемом сердечно-сосудистых препаратов, вероятностью заражения и тяжестью течения COVID-19 [5, 6]. Статины оказывают множественные иммуномодулирующие эффекты и могут способствовать повышению врожденного противовирусного иммунного ответа. Имеются неоспоримые доказательства того, что отказ от планового приема ингибиторов РААС существенно увеличивает риск сердечно-сосудистых катастроф (инфаркта миокарда (ИМ), инсульта). Пациентам любого возраста, принимающим ацетилсалициловую кислоту (АСК) в низких дозах при заболеваниях сердца, следует продолжить прием препарата. Пациенты, планово принимающие оральные антикоагулянты, должны продолжить их прием [5].

У пациентов с ХКС и подтвержденной вирусной пневмонией необходимо рассмотреть вопрос о назначении низкомолекулярного гепарина (НМГ) на основании тяжести поражения легких, оценки риска тромбоэмболических и геморрагических осложнений [12-14].

В случае назначения комбинированной терапии лопиновира с ритонавиром следует помнить о возможности развития лекарственных взаимодействий и не назначать ее совместно с клопидогрелем, тикагрелором, ивабрадином, ранолазином, симвастатином. При назначении лопинавира с ритонавиром максимальная суточная доза розувастатина составляет 10 мг/сут., аторвастатина -20 мг/сут., может потребоваться снижение дозы ББ. При назначении гидроксихлорохина может потребоваться снижение дозы метопролола и небиволола [6]. С учетом повышенного риска развития желудочковых аритмий на фоне приема гидроксихлорохина и азиромицина целесообразно воздержаться от применения этих препаратов у пациентов с ХКС в амбулаторных условиях и без динамического электрокардиографического (ЭКГ) контроля интервала QТ $[12,13,15$, 16].
Резюме:

1. Пациенты с ХКС составляют группу риска тяжелого течения COVID-19 и смерти, а также обострения ранее стабильного течения ИБС

2. Пациентам с XKC и COVID-19 рекомендуется продолжить прием всех плановых кардиологических препаратов с особым вниманием к терапии, стабилизирующей атеросклеротическую бляшку (статины, аспирин, блокаторы РААС, ББ).

3. У пациентов с ХКС и подтвержденной вирусной пневмонией необходимо рассмотреть вопрос о назначении НМГ на основании тяжести поражения легких, оценки риска тромбоэмболических и геморрагических осложнений.

4. В случае назначения комбинированной терапии лопиновира с ритонавиром противопоказан прием клопидогреля, тикагре лола, ивабрадина, ранолазина, симвастатина.

5. Целесообразно воздержаться от применения азитромицина и гидроксихлорохина у пациентов с ХКС в амбулаторных условиях и без динамического ЭКГ контроля интервала QT из-за увеличения риска развития желудочковых аритмий.

\section{3. Острый коронарный синдром}

ОКС - любое сочетание клинических признаков или симптомов, заставляющих подозревать острый ИМ или нестабильную стенокардию.

Консенсус китайских экспертов по диагностике и лечению острого ИМ в контексте профилактики и контроля COVID-19 выделяет 5 ключевых принципов для диагностики и лечения ОКС в условиях пандемии: близость места оказания медицинской помощи, обеспечение эпидемической безопасности пациентов и персонала, транспортировка в назначенные лечебные учреждения, дистанционные консультации, приоритет тромболизиса в лечении [17].

Подробно эти ключевые принципы рассмотрены в рекомендациях [5] Российского кардиологического общества. В целом тактика ведения пациентов с ОКС не должна отличаться от стандартно принятой [6].

Маршрутизация пациентов. Пациенты с ОКС и с подозрением на COVID-19 должны направляться в стационары, имеющие возможность проведения чрескожного коронарного вмешательства (ЧKB) [6].

В случае наличия в регионе нескольких ЧКВцентров, расположенных на небольшом расстоянии (например, в пределах одного города) следует рассмотреть возможность направлять пациентов с подтверждённой COVID-19 или высоким риском инфекции (симптомы, установленный контакт с больным) и ОКС в один изолированный ЧКВцентр.

При наличии только одного ЧКВ-центра, располагающего несколькими рентгеноперационными, одна из них должна быть выделена в изолированную зону для инфицированных пациентов, со строгим разделением потоков пациентов c COVID-19 (или её высокой вероятностью) и неинфицированных, включая раздельные палаты реанимации и интенсивной терапии. 
При наличии одного ЧКВ-центра с одной рентгеноперационной необходимо разделение потоков пациентов в зависимости от эпидемиологического статуса, включая раздельные палаты реанимации и интенсивной терапии, и внедрение протокола проведения интервенционных вмешательств инфицированным пациентам с соблюдением необходимых мер защиты и проведением заключительной дезинфекции.

При изменении порядка маршрутизации пациентов с ОКС необходимо учитывать имеющиеся региональные особенности (доступные возможности проведения реперфузионной терапии, дополнительный коечный фонд, возможности амбулаторного наблюдения в случае ранней выписки), текущую эпидемиологическую ситуацию и её прогнозируемую динамику [5].

Обеспечение эпидемической безопасности пациентов и персонала. Оценку эпиданамнеза, наличия симптомов, характерных для COVID-19 (особенно одышки), измерение температуры тела необходимо проводить на возможно более ранних этапах оказания помощи, оптимально - на догоспитальном этапе. Больных с высокой вероятностью наличия COVID-19 необходимо госпитализировать в профилированные стационары, при их наличии в регионе.

В учреждениях на уровне приёмных отделений необходимо организовать оценку поступающих пациентов с ОКС, более детальную у пациентов в стабильном состоянии. Потоки пациентов с ОКС без симптомов вирусной инфекции или пневмонии, с низкой вероятностью COVID-19, и пациентов с известным контактом с инфицированными и/или симптомами COVID-19 целесообразно разделить с момента поступления в стационар, однако все экстренно госпитализированные в стационар пациенты, вплоть до лабораторного исключения COVID-19, должны рассматриваться как инфицированные.

Экстренная помощь пациентам должна оказываться с неукоснительным соблюдением мер эпидемиологической защиты, необходима специальная подготовка персонала для минимизации связанных с данными мерами задержек.

Экстренно госпитализируемые с представлением об ОКС пациенты должны подвергаться в стационаре тестированию на COVID-19. У пациентов с отрицательным тестом в стабильном состоянии следует рассматривать раннюю выписку из стационара на амбулаторное наблюдение для увеличения доступности коечного фонда и снижения риска инфицирования в условиях стационара.

Транспортировка. Следует рассматривать прямую транспортировку пациентов наиболее высокого риска в региональные сосудистые центры даже из отдалённых районов. Стабильные пациенты с ОKC без подъёма сегмента ST (ОКСбпST), как и стабильные пациенты с ОКС с сопутствующей
COVID-19, могут направляться в региональные стационары без возможности проведения инвазивных вмешательств с целью снижения нагрузки на ведущие стационары региона, осуществляющие оказание высокотехнологичной помощи, с последующим переводом для ЧКВ в случае дестабилизации или рекомендацией отсроченного проведения вмешательства в случае эффективности консервативной терапии [5].

Диагностика и дистанционные консультации. Специфическое поражение миокарда, характерное для COVID-19 и часто сопровождающееся повышением уровня тропонина, может создавать трудности при дифференциальной диагностике и способствовать гипердиагностике OKC на фоне COVID-19 [5, 6].

Рекомендуется организация региональных консультативных центров для распределения потоков пациентов, в т.ч. в зависимости от вероятности, сопутствующей COVID-19, проведения дистанционных консультаций, включая передачу ЭКГ для решения вопроса о целесообразности тромболитической терапии и принятии решения о маршруте госпитализации.

Рекомендуется организация амбулаторного наблюдения пациентов, выписанных из стационара, с использованием дистанционных технологий, с целью поддержки ранней выписки из стационара пациентов, находящихся в стабильном состоянии [5].

Лечебные рекомендации. При оказании помощи пациентам с OKC в сочетании с COVID-19 или при подозрении на COVID-19 следует придерживаться принципов действующих клинических рекомендаций по диагностике и лечению ОКС как в части определения тактики лечения, так и в отношении медикаментозной терапии.

Следует учитывать возможность значимых межлекарственных взаимодействий при одновременном назначении противовирусных препаратов со статинами, антиагрегантными препаратами и пероральными антикоагулянтами, однако в настоящее время данная проблема изучена недостаточно для обоснования практических рекомендаций [5].

OKC с подъемом сегмента ST (OKCпST). При OKCпST в качестве оптимального метода реперфузионной терапии в ранние сроки заболевания следует рассматривать проведение первичного ЧКВ, если возможна своевременная транспортировка пациента в инвазивный стационар. Высокая частота отсутствия обструктивного поражения коронарного русла по данным коронарной ангиографии у пациентов с OKСпST в сочетании с COVID-19 и необходимость строгих противоэпидемических мер не должны служить ограничением для проведения коронарографии пациенту с убедительными клиническими проявлениями заболевания. Вместе с тем, в случае тяжёлого течения COVID-19, наличия 
пневмонии, требующей наблюдения в условиях отделения реанимации, проведения респираторной поддержки, вероятность развития ИМ 1 типа низка, и проведение коронарографии, в большинстве случаев, нецелесообразно [5].

В рекомендациях международной группы интервенционных кардиологов и специалистов по острой кардиологической помощи отмечается, что в первую очередь желательно попытаться применить стратегию механической реваскуляризации в соответствии с местными возможностями [18].

Вместе с тем, отмечено, что около 20-30\% пациентов с COVID-19 имеют повреждение миокарда с увеличением количества тропонинов I и T, что приводит к ИМ 2 типа. В частности, чем больше дыхательная и полиорганная недостаточность, старше возраст пациентов, тем больше увеличение тропонина, поэтому у этой категории пациентов соотношение риска и пользы инвазивной процедуры должно быть соответствующим образом оценено, в особенности у пациентов, у которых нет гемодинамической нестабильности, и, следовательно, оптимальная медикаментозная терапия в таких ситуациях является разумной [18, 19].

В российских рекомендациях отмечается, что тромболитическую терапию необходимо рассматривать при невозможности своевременной транспортировки пациента с OKCпST в инвазивный стационар или ограниченности ресурсов ЧКВ-центра, в т.ч. невозможности безопасно выполнить вмешательство в рекомендуемые сроки пациенту с подтверждённой COVID-19 или высокой её вероятностью. Ограниченные возможности выполнения первичных ЧКВ инвазивными стационарами в условиях неблагоприятной эпидемиологической ситуации следует рассматривать как основание для расширения использования тромболитической терапии на догоспитальном этапе [5].

В комплекс стандартной медикаментозной терапии входят АСК, нефракционированный гепарин (НФГ), статины, нитраты при наличии боли в груди, если позволяет гемодинамика [20].

OKСбпST. У пациентов с ОКСбпST в сочетании с COVID-19 следует проводить тщательную дифференциальную диагностику и стратификацию риска для определения показаний к проведению коронарографии. У пациентов очень высокого риска, согласно действующим рекомендациям, следует рассматривать проведение коронарографии в короткие сроки (ранняя инвазивная стратегия).

У пациентов с подтверждённой или предполагаемой COVID-19 в сочетании с OKСбпST промежуточного риска, у клинически стабильных пациентов высокого риска, а также при предполагаемом ИМ 2 типа, предпочтительна первоначальная консервативная стратегия, с выполнением коронарографии в случае дестабилизации состояния либо отсрочено, после выздоровления от коронавирусной инфекции. В сравнении с проведением стресстестов компьютерная томография (KT)-коронарная ангиография более предпочтительна для исключения обструктивного поражения коронарных артерий у пациентов, госпитализированных с представлением об ОКСбпST [5].

В комплекс стандартной медикаментозной терапии входят АСК, НФГ или НМГ, статины, если позволяет гемодинамика - ББ и нитраты при наличии боли в груди [20, 21].

Вопросы антикоагулянтной и антиагрегантной терапии у пациентов с COVID-19 рассмотрены в обзоре американских ученых [19]. Пациентам, страдающим ОКС, при отсутствии противопоказаний следует немедленно назначить АСК (160-325 мг) без кишечнорастворимой оболочки, с последующим приемом в низкой дозе (80 мг) длительно. Ингибиторы Р2Y 12 (клопидогрель, тикагрелор или прасугрел), двойная и тройная антиагрегантная терапия назначаются в соответствии с международными рекомендациями [21-23].

Резюме:
1. Смертность от острого ИМ составляет $40 \%$ общей смертности
пациентов с COVID-19.
2. При организации медицинской помощи пациентам с ОКС
в условиях пандемии необходимы четкая маршрутизация
и транспортировка пациентов, обеспечение эпидемической
безопасности пациента и персонала, возможность дистанцион-
ной консультативной помощи пациентам.
3. При оказании помощи пациентам с ОКС и подозрении
на СОVID-19 или в сочетании с СОVID-19 целесообразно сле-
довать принципам действующих клинических рекомендаций
по диагностике и лечению ОКС как для определения тактики
лечения, так и в отношении медикаментозной терапии.
4. При ОКСпST в качестве оптимального метода реперфузионной
терапии в ранние сроки заболевания следует рассматривать
проведение первичного ЧКВ, если возможна своевременная
транспортировка пациента в инвазивный стационар.
5. В условиях пандемии СОVID-19 целесообразно расширение
использования тромболитической терапии.

\section{4. Нарушение ритма сердца}

Нарушения сердечного ритма являются одним из наиболее частых сердечно-сосудистых осложнений при COVID-19. Распространенность аритмий варьирует от 6,9\% при легком течении COVID-19 до $44 \%$ при тяжелом ее течении [1]. К механизмам возникновения аритмий при COVID-19 относят: нарушение метаболизма и гипоксию; гипокалиемию, генез которой связан с потенциальным воздействием вируса на РААС; развитие вирусного миокардита с нарушением проводимости и желудочковыми аритмиями [5]. Некоторые препараты, применяемые в лечении COVID-19, могут приводить к удлинению интервала QT и повышать риск возникновения желудочковой тахикардии (ЖТ) типа “пируэт” [24].

У пациентов с COVID-19 могут возникать как наджелудочковые, так и желудочковые нарушения 
Таблица 1

Шкала Tisdale риска

лекарственно-индуцированного удлинения корригированного интервала QТ (QTc)

\begin{tabular}{ll}
\hline Фактор риска & Баллы \\
\hline Возраст $\geqslant 68$ лет & 1 \\
\hline Женский пол & 1 \\
\hline Петлевые диуретики & 1 \\
\hline Калий плазмы крови $\leqslant 3,5$ ммоль/л & 2 \\
\hline Исходное удлинение интервала QTс $\geqslant 450$ мсек & 2 \\
\hline Инфаркт миокарда & 2 \\
\hline Сепсис & 3 \\
\hline Сердечная недостаточность & 3 \\
\hline Каждый препарат, удлиняющий QТс & 3 \\
\hline Максимальное количество баллов & 21 \\
\hline
\end{tabular}

Примечание: количество баллов $\leqslant 6$ свидетельствует о низком риске, 7-10-среднем риске и $\geqslant 11$-высокий риск медикаментозной пролонгации QT.

сердечного ритма. Появление наджелудочковых аритмий, как правило, имеет благоприятный прогноз и не требует срочного перевода пациента в отделение реанимации и интенсивной терапии, исключения составляют больные с нестабильной гемодинамикой [6].

Возникновение желудочковых нарушений сердечного ритма следует расценивать как потенциально жизнеугрожающие аритмии, особенно если пациент получает противовирусную терапию. Вероятно, частота развития ЖТ на фоне этой терапии крайне невысока, однако необходимо помнить о вероятном удлинении интервала QT. К удлиняющим интервал QT средствам относятся следующие: хлорохин, гидроксихлорохин, комбинация лопинавира с ритонавиром, азитромицин. Для стратификации риска лекарственно-индуцированного удлинения корригированного интервала QT (QTc) используют шкалу Tisdale (таблица 1) [25].

К обязательным методам исследования пациентов с COVID-19 и нарушениями сердечного ритма относят: стандартную ЭКГ в 12 отведениях, определение уровня калия в биохимическом анализе крови, трансторакальную эхокардиографию (ЭхоКГ) [6].

При исходно нормальном значении QTс $(<450$ мсек) контроль ЭКГ необходимо выполнить на следующий день после первого приема противовирусной терапии. Если у пациента в анамнезе есть врожденный или приобретенный синдром удлиненного QT, брадикардия <50 уд./мин, структурная патология сердца или больной уже принимает препараты, удлиняющие интервал QТс, то контроль ЭКГ необходимо проводить через 4 ч после первого приема противовирусных препаратов. Уровень калия в плазме крови до назначения противовирусной терапии не должен быть $<3,5$ ммоль/л [6].
Лечение нарушений сердечного ритма во время пандемии COVID-19 проводится исходя из общих клинических рекомендаций [6]. Купирующая терапия пароксизмов аритмии осуществляется дифференцировано в зависимости от стабильности гемодинамических показателей и вида нарушений сердечного ритма. У больных со стабильной гемодинамикой для восстановления синусового ритма при пароксизме ФП рекомендованы к использованию препараты IC и III класса [26, 27]. Пациентам без признаков тяжелой органической патологии сердца и с сохраненной систолической функцией ЛЖ показано применение пропафенона [8]. Фармакодинамика пропафенона позволяет назначать препарат в таблетированной форме в виде нагрузочной дозы 450-600 мг и использовать его в амбулаторных условиях самостоятельно пациентом, что снижает необходимость в госпитализации больных во время пандемии COVID-19. Высокая эффективность и безопасность пропафенона (пропанорма) в купирующей терапии ФП была продемонстрирована в многоцентровом клиническом исследовании "Прометей” [28]. Неотложная терапия при пароксизме ФП у пациентов с ХСН или низком АД должна проводиться с назначением инфузии амиодарона, при нестабильной гемодинамике - электрическая кардиоверсия. Лечение ЖТ включает внутривенное введение ББ, амиодарона и/или проведение электроимпульсной терапии и сердечно-легочной реанимации.

Для удержания синусового ритма при пароксизмальной форме ФП у пациентов без грубой органической патологии сердца и больных с АГ рекомендованы антиаритмические препараты IC класса, в первую очередь пропафенон. При наличии грубой структурной патологии сердца рекомендованы препараты III класса, у пациентов ХCН препаратом выбора является амиодарон [27].

Проводимая терапия для лечения COVID-19 может иметь лекарственное взаимодействие с антиаритмическими препаратами и антикоагулянтами. При назначении хлорохина или гидроксихлорохина, комбинированной терапии лопинавира с ритонавиром следует с осторожностью назначать: дабигатран, варфарин, дигоксин, ББ. Необходим обязательный мониторинг ЭКГ с возможной коррекцией дозы лекарственных препаратов. Применение амиодарона противопоказано при назначении хлорохина/гидроксихлорохина, а также комбинированной терапии лопинавира с ритонавиром [6].

Прогноз пациентов зависит от вида нарушений сердечного ритма и тяжести течения COVID-19. У больных с COVID-19 легкой и средней степени тяжести прогноз благоприятный. У пациентов с тяжелым течением COVID-19 появление аритмий значительно ухудшает прогноз [29]. 
Резюме:

1. Нарушения сердечного ритма являются одним из наиболее частых сердечно-сосудистых осложнений при COVID-19.

2. К механизмам возникновения аритмий при COVID-19 относят: нарушение метаболизма и гипоксию; гипокалиемию; развитие вирусного миокардита со злокачественными тахиаритмиями

3. Некоторые препараты, применяемые в лечении COVID-19, могут приводить к удлинению интервала QT и повышать риск возникновения ЖТ типа "пируэт"

4. При назначении хлорохина или гидроксихлорохина, а также комбинированной терапии лопинавира с ритонавиром следует учитывать лекарственное взаимодействие с антиаритмическими препаратами и антикоагулянтами.

\section{5. Миокардит и перикардит}

Миокардит - воспалительное заболевание миокарда, подтверждённое наличием определённых гистологических, иммунологических и иммуногистохимических критериев, к которым относят: доказанное наличие воспалительного инфильтрата, локализованное в пределах миокарда, связанное с дегенерацией и некрозом миоцитов неишемического генеза. Иммуногистохимическим подтверждением миокардита является наличие $\geqslant 14$ лейкоцитов $/ \mathrm{Mм}^{2}$, в т.ч. до 4 моноцитов $/ \mathrm{Mм}^{2}$ с наличием $\mathrm{CD} 3+\mathrm{T}$-лимфоцитов $\geqslant 7$ клеток $/ \mathrm{Mм}^{2}$ в миокардиальном биоптате [30].

Предположительная частота миокардитов составляет 22 случая на 100 тыс. пациентов в год. Острый миокардит достоверно чаще встречается у пациентов молодого возраста.

При COVID-19 миокардит относится к числу распространенных осложнений с частотой 8-12\% $[31,32]$, описаны и развития фульминантного (молниеносного) миокардита в условиях высокой вирусной нагрузки [33]. В 33\% случаев сочетанное повреждение миокарда способствовало ухудшению течения заболевания, приводя к развитию фатальных событий [5].

Патофизиология миокардита, связанного c COVID-19, представляет собой комбинацию прямого вирусного повреждения кардиомиоцитов, системного воспаления, интерстициального фиброза миокарда, повреждения миокарда, связанного с интерферон-опосредованным иммунным ответом и преувеличенный ответ цитокинов Т-хелперами 1 и 2 типа [31, 34, 35].

При эндомиокардиальной биопсии при COVID-19 выявляются диффузные T-лимфоцитарные воспалительные инфильтраты со значительным интерстициальным отеком и ограниченным очаговым некрозом [36].

Клиническая картина миокардита характеризуется вариабельностью и малоспецифичностью. Основные причины варьирования клинической картины - это степень и протяженность зоны воспалительного поражения сердечной мышцы, а также наличие и выраженность кардиосклероза.
В клиническом исследовании, в которое были включены 112 пациентов с COVID-19, признаки миокардита были выявлены у 14 (12,5\%) пациентов. Большинство пациентов имели нормальный уровень тропонина при поступлении, который у 42 $(37,5 \%)$ пациентов увеличился во время госпитализации, особенно у умерших, у которых уровни тропонина были значительно увеличены за неделю до смерти [37].

Из других биомаркеров наряду с тропонинами I и Т для диагностики миокардита используются креатинфосфокиназа-МB (KФК-MB) и NT-proBNP, отражающий степень выраженности СН. Из диагностических исследований проводится ЭКГ, ЭхоКГ, при необходимости показано проведение трансторакальной ЭхоКГ [5].

Выполнение магнитно-резонансная томография (МРТ) сердца, в соответствии с рекомендациями Российского кардиологического общества, следует обсуждать в каждом конкретном случае кардиологической командой экспертов [5].

Собственно медикаментозное лечение миокардита на сегодняшний день в большинстве случаев представляет из себя посиндромную терапию $\mathrm{CH}$ и нарушений ритма, проводимую по принципам, предусмотренным соответствующими рекомендациями. В качестве перспективного препарата в лечении миокардита при COVID-19 рассматривается внутривенное введение иммуноглобулина [38].

У пациентов с низким сердечным выбросом, не отвечающим на медикаментозную терапию, показана механическая поддержка кровообращения. В качестве временной кардиореспираторной поддержки по показаниям возможно рассмотреть применение вено-артериальной экстракорпоральной мембранной оксигенации [5].

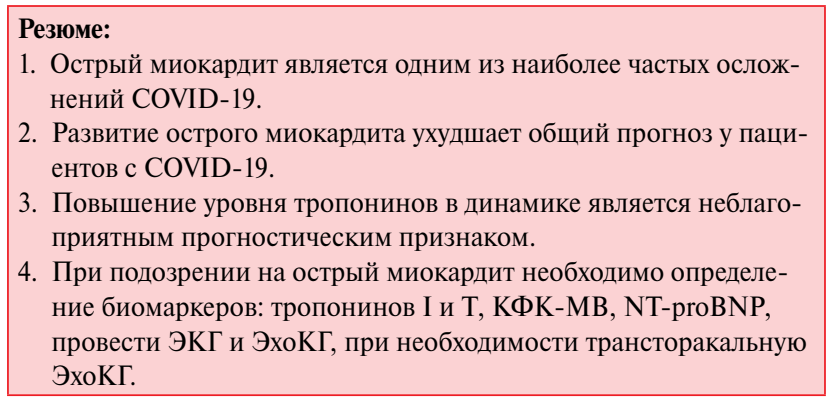

Перикардит. Поражения перикарда могут быть изолированными или являться составной частью при других заболеваниях, включая системные. Наиболее распространенным заболеванием перикарда в клинической практике является перикардит. Встречаемость острого перикардита составляет 27,7 случая на 100 тыс. населения в год, а частота связанных с ним госпитализаций - 3,32 на 100 тыс. человеко-лет. Внутрибольничная летальность при остром перикардите составляет $1,1 \%$ и увеличивается с возрастом, а также при развитии тяжелых 
инфекций (пневмония, септицемия) [39]. При COVID-19 описаны случаи развития острого перикардита [40-43], в т.ч. и с тампонадой сердца [44].

Предполагается, что воспаление перикарда при COVID-19 осуществляется через прямые цитотоксические эффекты и/или иммуноопосредованные механизмы [45].

Клинический диагноз перикардита может быть поставлен по двум критериям: 1) боль в груди (>8590\% случаев) - обычно острая, подобная плевриту, ослабевающая в положении сидя с наклоном вперёд; 2) шум трения перикарда $(\leqslant 33 \%$ случаев) поверхностный скребущий или скрипящий звук, лучше всего слышимый по левой границе грудины. Характерны изменения ЭКГ (до 60\% случаев) с новым распространённым подъёмом сегмента ST или депрессией сегмента PR в острую фазу, и определяемый инструментальными методами- выпот в полость перикарда (до 60\% случаев, обычно умеренный) [46].

Диагноз преобладающего перикардита с вовлечением миокарда, или "миоперикардита", может быть клинически установлен, если есть определённые критерии острого перикардита, а также повышенные маркеры повреждения миокарда (тропонин I или Т, КФК-МВ) без новой локальной или диффузной недостаточности ЛЖ по данным ЭхоКГ или магнитно-резонансного исследования сердца [46]. Термин “миоперикардит" отражает первично перикардитический синдром с минимальным вовлечением миокарда, который относится к большинству сочетаний мио- и перикардитов в клинической практике [46].

Необходимо помнить, что среди неинфекционных причин перикардитов важное место занимают иммуновоспалительные ревматические заболевания, при которых частота вовлечения перикарда в процесс может достигать 50-80\%. Поэтому эта категория пациентов входит в группу особого риска в плане развития перикардита при COVID-19.

Из 83 пациентов с тяжелой и критической COVID-19, которым проведена KT легких, у 4,8\% был обнаружен выпот в перикарде, а у $6 \%$ пациентов была зарегистрирована боль в груди, что позволяет предполагать, что острый перикардит может быть недостаточно диагностированной патологией у этих пациентов [43].

При подозрении на острый перикардит необходимо оценить анализ крови с параметрами воспалительного и миокардиального повреждения, провести ЭКГ и трансторакальную ЭхоКГ [41].

Эксперты Европейского общества кардиологов (ESC) отмечают, что на сегодняшний день нет лекарственных препаратов, содержащих в инструкции по применению показание "перикардит", поэтому вся медикаментозная терапия заболеваний перикарда является off-label, т.е. назначается по показаниям, не утвержденным регулирующими органами [40]. В соответствии с рекомендациями ESC [46], рецидивирующий перикардит следует лечить этиотропно, если причина известна. Ведущее место в терапии занимают АСК и нестероидные противовоспалительные препараты (НПВП). Дополнительно рекомендуется колхицин поверх стандартной противовоспалительной терапии. При недостаточной эффективности лечения АСК/ НПВП и колхицин, можно дополнительно использовать глюкокортикостероиды (ГКС) в низких или средних дозах - в виде тройной терапии АCK/ НПВП + колхицин + ГКС. Назначение ГКС рекомендуется избегать при бактериальных инфекциях и туберкулезе.

Показания для назначения, длительность лечения и дозы ГКС для лечения перикардита у пациентов с COVID-19 требуют дополнительного изучения. В литературе описана эффективность внутривенного введения высоких доз метилпреднизолона в течение 3-х дней при лечении острого перикардита у пациента с COVID-19, с последующим пероральным приемом преднизолона и колхицина [42].

Риск рецидивирующего течения перикардита при COVID-19 в настоящее время неизвестен.

Резюме:
1. Острый перикардит является возможным осложнением
COVID-19.
2. В качестве дополнительного фактора риска перикардита при
COVID-19 следует рассматривать наличие у пациента иммуно-
воспалительных ревматических заболеваний.
3. При проведении КТ легких необходимо оценивать состояние
перикарда.
4. При подозрении на острый перикардит необходимо выполнить
анализ крови с параметрами воспалительного и миокардиаль-
ного повреждения, провести ЭКГ и трансторакальную ЭхоКГ.

\section{6. Сердечная недостаточность}

K наиболее тяжелым коморбидным состояниям у пациентов с COVID-19 можно отнести XCH. Распространенность ХCH среди госпитализированных пациентов с COVID-19 составляет в среднем 23\%, при этом большая часть пациентов составляет группу риска тяжелого течения COVID-19 и ее осложнений. Смертность от COVID-19 среди больных с систолической ХСН в несколько раз выше, чем у пациентов с сохраненной сократительной функцией ЛЖ. Данная группа населения уязвима и более склонна к раннему присоединению инфекции и ее негативным исходам [5].

$\mathrm{K}$ наиболее значимым механизмам декомпенсации XCH при инфицировании вирусом SARS-CoV-2 относят: негативное влияние лихорадки любого происхождения на водно-солевой обмен и увеличение нагрузки на сердце; повреждение миокарда опосредованное избыточной активацией цитокинов (возникновение цитокинового шторма); прямое действие вируса на миокард с развитием миокардита [47]. 
Значимость вклада имеющейся органической патологии сердца в контексте легочных осложнений COVID-19 варьирует от наличия классической XCH с сохраненной фракцией выброса ЛЖ на более ранних стадиях до развития острой систолической $\mathrm{CH}$ как патологического ответа на цитокиновую фазу течения COVID-19 на позднем этапе заболевания [5].

Повышение маркеров повреждения миокарда является предиктором тяжелого течения COVID-19 и смерти. У некоторых пациентов наблюдается экстремальное повышение уровня натрийуретических пептидов, причиной смерти которых в каждом четвертом случае является $\mathrm{CH}$ и остановка сердца. В редких случаях наблюдается подобное фульминантному миокардиту течение COVID-19, однако по данным биопсии отмечается лишь незначительная мононуклеарная воспалительная инфильтрация интерстиция без признаков существенного повреждения миокарда [47].

У пожилых пациентов с СС3, осложненными XCH и COVID-19, существенно увеличивается риск развития ОКС вследствие повышенной вязкости крови при лихорадке, прокоагулянтных эффектов воспаления, дисфункции эндотелиальных клеток [6].

Пациенты с ХСН должны тщательно следовать рекомендациям по профилактике заражения и самоизоляции, чтобы избежать инфицирования COVID-19. Учитывая возможность резкого ухудшения самочувствия пациентов с ХСН и ОРВИ, с подтверждённой COVID-19 или высоким риском инфекции, все больные должны быть госпитализированы независимо от тяжести течения $[5,6]$. Острая декомпенсация CH при COVID-19 требует срочной госпитализации в отделение реанимации и интенсивной терапии.

Лечение ХСН имеет свои особенности у пациентов с COVID-19. Необходим ежедневный контроль объема выпитой и выделенной жидкости, массы тела и соблюдение рационального питьевого режима: резкое сокращение приема жидкости $(<1,5$ л) при лихорадке у больного ХСН нецелесообразно, употребление $>2$ литров может привести к нарастанию застоя в легких [47].

У пациентов с бессимптомным носительством или на очень ранней стадии COVID-19 без легочных осложнений необходимо продолжать прием плановой базовой терапии ХСН, включающий назначение иАПФ или БРА, антагонистов минералкортикоидных рецепторов, ББ. При развитии COVID-19-accoциированной пневмонии и острого респираторного дистресс-синдрома (ОРДС) терапия иАПФ и БРА может быть временно остановлена [48-50]. При принятии решения следует учитывать уровень АД, выраженность дисфункции почек и потенциальные риски отмены данных препаратов.

Антагонисты минералокортикоидных рецепторов назначаются в полном объеме при отсутствии противопоказаний. Предпочтение следует отдавать спиронолактону. Доза спиронолактона зависит от выраженности отечного синдрома. При наличии выраженной гепатомегалии, асцита, резистентности к диуретическим препаратам доза препарата должна быть увеличена до 300-400 мг/сут. в условиях ежедневного контроля калия и натрия в крови [48].

Терапия ББ должна быть продолжена, у пациентов с синусовым ритмом. При тяжелом течении COVID-19 рекомендуется назначение НМГ, по крайней мере, в профилактической дозе [6].

При назначении комбинированной противовирусной терапии лопинавира с ритонавиром запрещено использование эплеренона. Лечение хлорохином/гидроксихлорозином или комбинированной противовирусной терапии может потребовать коррекции дозы дигоксина и ББ [50].

Резюме:
1. ХСН значительно ухудшает прогноз больных с COVID-19.
2. Учитывая возможность резкого ухудшения самочувствия
пациентов с ХCH и ОРВИ, с подтвержденной COVID-19
или высоким риском инфекции, все больные должны быть
госпитализированы независимо от тяжести течения.
3. У пациентов без легочных осложнений COVID-19 необходимо
продолжать прием плановой базовой терапии ХCH. При
тяжелом течении COVID-19 следует рассмотреть возможность
назначения НМГ.

\section{7. Тромбоэмболия легочной артерии}

Пациенты с COVID-19 имеют высокий риск тромботических осложнений, частота которых колеблется по данным разных наблюдений от 8 до $27 \%$ [51-53]. Клинически тромботические осложнения у пациентов с COVID-19 проявляются тромбоэмболией легочной артерии (ТЭЛА), тромбозами глубоких вен, ишемическим инсультом, ОКС. Риск развития ТЭЛА у пациентов с ОРДС, вызванным COVID-19 в 3 раза выше, чем у больных с ОРДС другой этиологии [54].

Обсуждаются разнообразные механизмы развития ТЭЛА при COVID-19. Помимо традиционных факторов риска венозного тромбоза рассматривается роль локального внутрилегочного усиления тромбообразования вследствие повреждения эпителия респираторного тракта, дисфункция тромбоцитов и эндотелиальных клеток, развитие синдрома диссеминированного внутрисосудистого свертывания $[55,56]$. Распространенность синдрома диссеминированного внутрисосудистого свертывания у госпитализированных пациентов составляет $0,6 \%$ среди выживших и 71,4\% у умерших больных. Факторами риска развития ТЭЛА являются пожилой возраст, длительное пребывание больного в отделении реанимации и интенсивной терапии.

Диагностика ТЭЛА у пациентов с COVID-19 может вызвать определенные трудности из-за схожести клинических симптомов. Повышение только 
уровня D-димера у пациентов с COVID-19 не может использоваться в качестве доказательства тромботических осложнений. Признаки дисфункции правых отделов сердца и легочная гипертензия при ЭхоКГ могут наблюдаться у пациентов с пневмонией в отсутствие ТЭЛА. Необходима комплексная интерпретация клинической картины (ухудшение респираторных симптомов, нарастание гипоксемии, нестабильность гемодинамики) и данных лабораторного обследования для оценки вероятности ТЭЛА при COVID-19. Ведущая роль в диагностике ТЭЛА принадлежит выполнению КТ органов грудной клетки с внутривенным контрастированием [5].

Профилактику ТЭЛА стоит рассматривать для больных COVID-19, которые в условиях карантина лечатся дома и имеют высокий риск венозных тромбоэмболических осложнений, низкий риск кровотечений и не получают антикоагулянтного лечения по другим показаниям [6]. Назначение НМГ в профилактических дозах показано всем госпитализированным пациентам с COVID-19 и должно продолжаться как минимум до выписки. Нет доказанных преимуществ какого-либо одного НМГ по сравнению с другими. При недоступности НМГ или противопоказаниях к ним возможно использование НФГ. Увеличение дозы гепарина до промежуточной или лечебной может быть рассмотрено у больных с высоким и крайне высоким уровнем $\mathrm{D}$-димера, при наличии дополнительных факторов риска венозных тромбоэмболических осложнений, а также при тяжёлых проявлениях COVID-19 [6].

У коморбидных пациентов актуален вопрос профилактики осложнений со стороны желудочнокишечного тракта (ЖКТ) при назначении различных классов антитромбоцитарных препаратов как на амбулаторном, так и на госпитальном этапе во время пандемии COVID-19. С этой целью может

\section{Литература/References}

1. Huang $C$, Wang $Y, L i X$, et al. Clinical features of patients infected with 2019 novel coronavirus in Wuhan, China [published correction appears in Lancet. 2020 Jan 30; Lancet. 2020;395(10223):497-506. doi:10.1016/S0140-6736(20)30183-5.

2. Wu Z, McGoogan JM. Characteristics of and important lessons from the coronavirus disease 2019 (COVID-19) outbreak in China: summary of a report of 72314 cases from the Chinese center for disease control and prevention. JAMA . 2020 Feb 24. doi:10.1001/ jama.2020.2648.

3. Pranata R, Lim MA, Huang I, et al. Hypertension is associated with increased mortality and severity of disease in COVID-19 pneumonia: A systematic review, meta-analysis and meta-regression. J Renin Angiotensin Aldosterone Syst. 2020;21(2):1470320320926899. doi: $10.1177 / 1470320320926899$.

4. Ferrario CM, Jessup J, Gallagher PE, et al. Effects of reninangiotensin system blockage on renal angiotensin-(1-7) forming enzymes and receptors. Kidney Int. 2005;68:2189-96. doi:10.1111/j.1523-1755.2005.00675.x. быть использован универсальный гастроэнтеропротектор ребамипид. Препарат восстанавливает защитный барьер не только слизистых ЖКТ на всем его протяжении, но и других слизистых оболочек, включая количественный и качественный состав слизи дыхательных путей, а также обладает потенциалом для снижения воспаления в легких и сохранению альвеолярного эпителия путем ингибирования эпидермального фактора роста и уменьшения содержания провоспалительных цитокинов, что позволяет рекомендовать ребамипид пациентам c COVID-19 [57].

Больные с острой ТЭЛА и гемодинамической нестабильностью должны немедленно получить реперфузионную терапию. Для гемодинамически стабильных пациентов следует использовать лечебные дозы НМГ/НФГ [6].

В настоящее время нет данных о применении прямых пероральных антикоагулянтов при COVID-19. Пациентам, получающим пероральные антикоагулянты по другим показаниям, при не тяжелых проявлениях COVID-19, их прием можно продолжить. При назначении комбинированной противовирусной терапии лопиновира с ритонавиром и у пациентов с тяжелыми формами COVID-19 рекомендуется переход на лечебные дозы НМГ.

\section{Резюме:}

1. Пациенты с COVID-19 имеют высокий риск тромботических осложнений, в т.ч. ТЭЛА.

2. Диагностика ТЭЛА у пациентов с COVID-19 может вызвать определенные трудности, ведущая роль в диагностике ТЭЛА принадлежит выполнению КТ органов грудной клетки с внутривенным контрастированием.

3. Назначение НМГ в профилактических дозах показано всем госпитализированным пациентам с COVID-19 и должно продолжаться как минимум до выписки.

4. Когда острая ТЭЛА подтверждена, лечение должно быть основано на стратификации риска в соответствии с текущими рекомендациями.

5. Shlyakho EV, Konradi AO, Arutyunov GP, et al. Guidelines for the diagnosis and treatment of circulatory diseases in the context of the COVID-19 pandemic. Russian Journal of Cardiology. 2020;25(3):3801. (In Russ.) Шляхто Е. В. Конради А. О., Арутюнов Г.П., и др. Руководство по диагностике и лечению болезней системы кровообращения в контексте пандемии COVID-19. Российский кардиологический журнал. 2020;25(3):3801. doi:10.15829/1560-40712020-3-3801.

6. Temporary guidelines for Prevention, diagnosis and treatment of new coronavirus infection (COVID-19) version 7 (03.06.2020) of the Ministry of health of the Russian Federation. (In Russ.) Временные методические рекомендации Профилактика, диагностика и лечение новой коронавирусной инфекции (COVID-19) версия 7 (03.06.2020) Министерства здравоохранения Российской Федерации. https://www.rosminzdrav. ru/news/2020/06/03/14109-minzdrav-rossii-utverdil-7-versiyumetodicheskih-rekomendatsiy-po-lecheniyu-covid-19 
7. Kobalava ZD, Konradi AO, Nedogoda SV, et al. Arterial hypertension in adults. Clinical guidelines 2020. Russian Journal of Cardiology. 2020;25(3):3786. (In Russ.) Кобалава Ж.Д., Конради А. О., Недогода С.В., и др. Артериальная гипертензия у взрослых. Клинические рекомендации 2020. Российский кардиологический журнал. 2020;25(3):3786. doi:10.15829/1560-4071-20203-3786.

8. Oganov RG, Simanenkov VI, Bakulin IG, et al. Comorbidities in clinical practice. Algorithms for diagnostics and treatment. Cardiovascular Therapy and Prevention. 2019;18(1):566. (In Russ.) Оганов Р. Г., Симаненков В. И., Бакулин И. Г., и др. Коморбидная патология в клинической практике. Алгоритмы диагностики и лечения. Кардиоваскулярная терапия и профилактика. 2019;18(1):5-66. doi:10.15829/1728-8800-2019-1-5-66.

9. Burnier $M$, Bakris $G$, Williams $B$. Redefining diuretics use in hypertension: why select a thiazide-like diuretic? Journal of Hypertension. 2019;37:1574-86. doi:10.1097/ HJH.0000000000002088.

10. Report of the WHO-China Joint Mission on Coronavirus Disease 2019 (COVID-19). 16-24 February 2020. https://www.who.int/ docs/default-source/coronaviruse/who-china-joint-mission-oncovid-19-final-report.pdf.

11. 2019 ESC Guidelines for the diagnosis and management of chronic coronary syndromes The Task Force for the diagnosis and management of chronic coronary syndromes of the European Society of Cardiology (ESC). Russian Journal of Cardiology. 2020;25(2):3757. (In Russ.) Рекомендации ESC по диагностике и лечению хронического коронарного синдрома. Российский кардиологический журнал. 2020;25(2):3757. doi:10.15829/15604071-2020-2-3757.

12. COVID-19 Treatment Guidelines Panel. Coronavirus Disease 2019 (COVID-19) Treatment Guidelines. National Institutes of Health. https://covid19treatmentguidelines.nih.gov.

13. Gandhi R, Lynch J, del Rio C. Mild or Moderate Covid-19. N Engl J Med. 2020. doi:10.1056/NEJMcp2009249.

14. Thachil J, Tang N, Gando S, et al. ISTH interim guidance on recognition and management of coagulopathy in COVID-19. J Thromb Haemost. 2020;18(5):1023-6. doi:10.1111/jth.14810.

15. Geleris J, Sun Y, Platt J, et al. Observational Study of Hydroxychloroquine in Hospitalized Patients with Covid-19. N Engl J Med. 2020. doi:10.1056/NEJMoa2012410.

16. Cao B, Wang $Y$, Wen D, et al. A Trial of Lopinavir - Ritonavir in Adults Hospitalized with Severe Covid-19. N Engl J Med. 2020;382:1787-99. doi:10.1056/NEJMoa2001282/

17. $\mathrm{Bu} \mathrm{J}$, Chen $\mathrm{M}$, Cheng $\mathrm{X}$, et al. Consensus of Chinese experts on diagnosis and treatment processes of acute myocardial infarction in the context of prevention and control of COVID-19 (first edition) Nan Fang Yi Ke Da Xue Xue Bao. 2020;40(2):147-51. doi:10.12122/j.issn.1673-4254.2020.02.01.

18. Chieffo A, Stefanini GG, Price S, et al. EAPCI Position Statement on Invasive Management of Acute Coronary Syndromes during the COVID-19 pandemic..Eur Heart J. 2020;41(19):1839-51. doi:10.1093/eurheartj/ehaa381.

19. Mahmud E, Dauerman HL, Welt FG, et al. Management of Acute Myocardial Infarction During the COVID-19 Pandemic. J Am Coll Cardiol. 2020:S0735-1097(20)35026-9. doi:10.1016/j. jacc.2020.04.039.

20. Watson RA, Johnson DM, Dharia RN, et al. Anti-Coagulant and Anti-Platelet Therapy in the COVID-19 Patient: A Best Practices Quality Initiative Across a Large Health System. Hosp Pract (1995). 2020. doi:10.1080/21548331.2020.1772639.

21. Valgimigli $M$, Bueno $H$, Byrne RA, et al. 2017 ESC focused update on dual antiplatelet therapy in coronary artery disease developed in collaboration with EACTS. European Heart Journal 2018;39:213-260. doi:10.1093/eurheartj/ehx419.

22. 2015 ESC Guidelines for the management of acute coronary syndromes in patients presenting without persistent ST-segment elevation. Russian Journal of Cardiology. 2016;(3):9-63. (In Russ.) Рекомендации ESC по ведению пациентов с острым коронарным синдромом без стойкого подъема сегмента ST. Российский кардиологический журнал. 2016;(3):9-63. doi:10.15829/1560-4071-2016-3-9-63.

23. The Task Force for the management of acute myocardial infarction in patients presenting with st-segment elevation of the european society of cardiology (ESC) 2017 ESC Guidelines for themanagement of acutemyocardial infarction in patients presenting with ST-segment elevation. Russian Journal of Cardiology. 2018;23(5):103-58. (In Russ.) Рекомендации ESC по ведению пациентов с острым инфарктом миокарды с подьемом сегмента ST. Российский кардиологический журнал 2018;23(5):103-58. doi:10.15829/1560-4071-2018-5-103-158.

24. Guatret P, Lagier J-Ch, Parola P, et al. (2020) Hydroxychloroquine and azithromycin as a treatment of COVID-19: results of an open-label non-randomized clinical trial. Int $\mathrm{J}$ of Antimi Agents. 2020;105949. doi:10.1016/j.jiantimicag.2020.105949/

25. Tisdale JE, Jayes HA, Kingery JR, et al. Development and validation of a risk score to predict QT interval prolongation in hospitalized patients. Circ Cardiovasc Qual Outcomes. 2013;6:479-87. doi:10.1161/CIRCOUTCOMES.113.000152.

26. January CT, Wann LS, Calkins H. et all. 2019 AHA/ACC/HRS Focused Update of the 2014 AHA/ACC/HRS Guideline for the Management of Patients With Atrial Fibrillation, Heart Rhythm 2019. doi.org/10.1016/j.hrthm.2019.01.024.

27. Kirchhof P, Benussi S, Kotecha D, et al. ESC Guidelines for the management of atrial fibrillation developedin collaboration with EACTS. Russian Journal of Cardiology. 2017;(7):7-86. (In Russ.) Рекомендации ESC по лечению пациентов с фибрилляцией предсердий, разработанные совместно с EACTS. Российский кардиологический журнал, 2017;(7):7-86. doi:10.15829/15604071-2017-7-7-86.

28. Fomina IG, Tarzimanova Al, Vetluzhsky AV, et al. Propafenone in restoring sinus rhythm in patients with persistent atrial fibrillation. PROMETEY is an open, multicenter, pilot study in the Russian Federation. Cardiovascular Therapy and Prevention. 2005;4(4):66-9. (In Russ.) Фомина И. Г., Тарзиманова А.И., Ветлужский А. В. и др. Пропафенон при восстановлении синусового ритма у больных с персистирующей формой фибрилляции предсердий. "ПРОМЕТЕЙ" - открытое, мультицентровое, пилотное исследование в Российской Федерации. Кардиоваскулярная терапия и профилактика. 2005;4(4):66-9.

29. ESC Guidance for the Diagnosis and Management of CV Disease during the COVID-19 Pandemic. https://www.escardio.org/ Education/COVID-19-and-Cardiology/ESC-COVID-19-Guidance

30. Caforio ALP, Pankuweit S, Arbustini E, et al. European Society of Cardiology Working Group on Myocardial and Pericardial Diseases. Current state of knowledge on aetiology, diagnosis, management, and therapy of myocarditis: a position statement of the European Society of Cardiology Working Group on Myocardial and Pericardial Diseases. Eur Heart J. 2013;34(33):2636-48, 2648a-2648d. doi:10.1093/eurheartj/eht210.

31. Guzik TJ, Mohiddin SA, Dimarco A, et al. COVID-19 and the cardiovascular system: implications for risk assessment, diagnosis, and treatment options. Cardiovasc Res. 2020:cvaa106. doi:10.1093/cvr/cvaa106.

32. Bansal M. Cardiovascular disease and COVID-19. Diabetes Metab Syndr. 2020;14(3):247-50. doi:10.1016/j.dsx.2020.03.013. 
33. Chen C, Zhou Y, Wang DW. SARS-CoV-2: a potential novel etiology of fulminant myocarditis. Herz. 2020 May;45(3):230-2. doi:10.1007/s00059-020-04909-z.

34. Babapoor-Farrokhran S, Gill D, Walker J, et al. Myocardial injury and COVID-19: Possible mechanisms. Life Sci. 2020;253:117723. doi:10.1016/j.lfs.2020.117723.

35. Siripanthong B, Nazarian S, Muser D, et al. Recognizing COVID19-related myocarditis: the possible pathophysiology and proposed guideline for diagnosis and management. Heart Rhythm. 2020:S1547-5271(20)30422-7. doi:10.1016/j.hrthm.2020.05.001.

36. Sala S, Peretto G, Gramegna M, et al. Acute Myocarditis Presenting as a Reverse Tako-Tsubo Syndrome in a Patient With SARS-CoV-2 Respiratory Infection Eur Heart J. 2020 May 14;41(19):1861-2. doi:10.1093/eurheartj/ehaa286.

37. Deng Q, Hu B, Zhang $\mathrm{Y}$, et al. Suspected myocardial injury in patients with COVID-19: Evidence from front-line clinical observation in Wuhan, China. Int J Cardiol. 2020:S01675273(20)31115-3. doi:10.1016/j.ijcard.2020.03.087.

38. Kow CS, Hasan SS. Glucocorticoid versus immunoglobulin in the treatment of COVID-19-associated fulminant myocarditis. Infection. 2020:1-2. doi:10.1007/s15010-020-01441-4.

39. Kytö V, Sipilä J, Rautava P. Clinical profile and influences on outcomes in patients hospitalized for acute pericarditis. Circulation. 2014;130(18):1601-6. doi: 10.1161/CIRCULATIONAHA.114.010376.

40. Cizgici AY, Zencirkiran Agus H, Yildiz M. COVID-19 myopericarditis: It should be kept in mind in today's conditions Am J Emerg Med. 2020:S0735-6757(20)30310-7. doi: 10.1016/j.ajem.2020.04.080

41. Tung-Chen Y. Acute pericarditis due to COVID-19 infection: An underdiagnosed disease? Med Clin (Barc). 2020:S00257753(20)30257-8. doi:10.1016/j.medcli.2020.04.007.

42. Khalid N, Chen Y, Case BC, et al. COVID-19 (SARS-Cov-2) and the heart - An ominous association. Cardiovasc Revasc Med. 2020:S1553-8389(20)30256-6. doi:10.1016/j.carrev.2020.05.009.

43. Li K, Wu J, Wu F, et al. The clinical and chest CT features associated with severe and critical COVID-19 pneumonia. Invest Radiol. 2020 Jun;55(6):327-31. doi:10.1097/RLI.0000000000000672.

44. Hua A, O'Gallagher K, Sado D, Byrne J. Life-threatening cardiac tamponade complicating myo-pericarditis in COVID-19. Eur Heart J. 2020:ehaa253. doi:10.1093/eurheartj/ehaa253.

45. Inciardi RM, Lupi L, Zaccone G, et al. Cardiac involvement in a patient with coronavirus disease 2019 (COVID-19). JAMA Cardiol 2020; doi:10.1001/jamacardio.2020.1096.

46. Adler Y., Charron P., Imazio M., et al. 2015 ESC Guidelines for the diagnosis and management of pericardial diseases. Russian Journal of Cardiology. 2016;(5):117-62. (In Russ.) Рекомендации ESC по диагностике и ведению пациентов с заболеваниями перикарда. Российский кардиологический журнал. 2016;(5):117-62. doi:10.15829/1560-4071-2016-5-117-162.

\section{Раздел 2. Хронические заболевания лёгких 2.1. Хроническая обструктивная болезнь легких}

ХОБЛ - заболевание, характеризующееся персистирующим ограничением воздушного потока, которое обычно прогрессирует и является следствием хронического воспалительного ответа дыхательных путей и легочной ткани на воздействие ингалируемых повреждающих частиц или газов. Обострения и коморбидные состояния являются неотъемлемой частью болезни и вносят значительный вклад в клиническую картину и прогноз [1].
47. Xiong T-Y, Redwood S, Prendergast B, Chen M. Coronaviruses and the cardiovascular system: acute and long-term implications, European Heart Journal. 2020;41,19:1798-800. doi:10.1093/ eurheartj/ehaa231.

48. Mehra MR, Ruschitzka F. COVID-19 IIIness and Heart Failure: A Missing Link? JACC Heart Fail. 2020;8(6):512-4. doi:10.1016/j. jchf.2020.03.004.

49. HFSA/ACC/AHA Statement Addresses Concerns Re: Using RAAS Antagonists in COVID-19 https://www.acc.org/latest-incardiology/articles/2020/03/17/08/59/hfsa-acc-aha-statementaddresses-concerns-re-using-raas-antagonists-in-covid-19.

50. Driggin E, Madhavan MV, Bikdeli B, et al. Cardiovascular Considerations for Patients, Health Care Workers, and Health Systems During the COVID-19 Pandemic. J Am Coll Cardiol. 2020;75(18):2352-71. doi:10.1016/j.jacc.2020.03.031.

51. Llitjos J, Leclerc M, Chochois C, et al. High incidence of venous thromboembolic events in anticoagulated severe COVID-19 patients. J Thromb Haemost. 2020. doi:10.1111/jth.14869.

52. Helms J, Tacquard C, Severac F, et al. High risk of thrombosis in patients with severe SARS-CoV-2 infection: a multicenter prospective cohort study. Intensive Care Med. 2020. doi:10.1007/ s00134-020-06062-x.

53. Klok FA, Kruip MJHA, van der Meer NJM, et al. Incidence of thrombotic complications in critically ill ICU patients with COVID19. Thromb Res. 2020. doi:10.1016/ j.thromres.2020.04.013.

54. Menter T, Haslbauer J, Nienhold R, et al. Post-mortem examination of COVID19 patients reveals diffuse alveolar damage with severe capillary congestion and variegated findings of lungs and other organs suggesting vascular dysfunction. Histopathology. 2020. doi:10.1111/his.14134.

55. Paranjpe I, Fuster V, Lala A, et al. Association of Treatment Dose Anticoagulation with In-Hospital Survival Among Hospitalized Patients with COVID-19. Journal of the American College of Cardiology. 2020. doi:10.1016/ j.jacc.2020.05.001.

56. PulmCrit - Thrombosis update in COVID-19: Data from the Mount Sinai system in NYC. https://emcrit.org/pulmcrit/sinai/

57. Tkacheva ON, Kotovskaya YuV, Aleksanyan LA, et al. Novel coronavirus infection SARS-CoV-2 in elderly and senile patients: prevention, diagnosis and treatment. Expert Position Paper of the Russian Association of Gerontology and Geriatrics. Cardiovascular Therapy and Prevention. 2020;19(3):2601. (In Russ.) Ткачева О.Н., Котовская Ю.В, Алексанян Л.А. и др. Согласованная позиция экспертов Российской ассоциации геронтологов и гериатров. Новая коронавирусная инфекция SARS-CoV-2 (COVID19) у пациентов пожилого и старческого возраста: особенности профилактики, диагностики и лечения. Кардиоваскулярная терапия и профилактика. 2020;19(3):2601. doi:10.15829/1728-8800-2020-2601.

За последние 20 лет зарегистрировано увеличение заболеваемости на $68,9 \%$. В мире насчитывается 384 млн пациентов с ХОБЛ. Глобальная распространенность ХОБЛ составляет $11,7 \%$ [2].

Ведущим этиологическим фактором ХОБЛ является табакокурение. Вдыхание сигаретного дыма и других вредных частиц, таких как дым, в результате сжигания биоорганического топлива, приводит к воспалению в легочной ткани, этот нормальный ответ на повреждение у лиц, склонных к развитию ХОБЛ, модифицирован и патологически усилен. Воспаление характеризуется повыше- 
нием количества нейтрофилов, макрофагов и Тлимфоцитов (особенно CD8+) в различных частях дыхательных путей и легких, кроме того, определенную роль в патогенезе ХОБЛ играет дисбаланс в системе “протеазы-антипротеазы”. Такой воспалительный ответ может вызывать разрушение паренхимы (приводящее к эмфиземе) и нарушение работы нормальных защитных и восстановительных механизмов (приводящее к фиброзу мелких бронхов).

Клиническая картина ХОБЛ характеризуется однотипными клиническими проявлениями - хроническим кашлем и одышкой при физических нагрузках. Степень их выраженности зависит от стадии заболевания, скорости прогрессирования болезни и преимущественного уровня поражения бронхиального дерева. Выделяют две клинические формы заболевания - эмфизематозную и бронхитическую.

Наиболее важным для диагностики ХОБЛ является определение хронического ограничения воздушного потока, т.е. бронхиальной обструкции. Основным критерием, определяющим хроническое ограничение воздушного потока, или хроническую обструкцию, является падение показателя $\mathrm{OФB}_{1}$ до уровня, составляющего $<80 \%$ от должных величин. ХОБЛ сопровождается нарушением вентиляционно-перфузионных соотношений, что может приводить к артериальной гипоксемии - снижению напряжения кислорода в артериальной крови $\left(\mathrm{PaO}_{2}\right)$. Кроме того, вентиляционная дыхательная недостаточность приводит к повышению напряжения углекислоты в артериальной крови $\left(\mathrm{PaCO}_{2}\right)$.

Терапия ХОБЛ включает фармакологические и нефармакологические подходы. Фармакологические методы лечения включают бронходилататоры, комбинации ингаляционных ГКС и длительно действующих бронходилататоров, ингибиторы фосфодиэстеразы-4, теофиллин, а также вакцинацию против гриппа и пневмококковой инфекции.

COVID-19 - это респираторное и системное заболевание, которое может прогрессировать до тяжелой гипоксемии, требующей той или иной формы вентиляционной поддержки в 15-20\% подозреваемых и подтвержденных случаев [3]. Известно, что ХОБЛ связана с повышенным риском заболеваемости и смертности при внебольничной пневмонии. К способствующим факторам относятся: изменения местного/системного воспалительного ответа, нарушение иммунитета хозяина, дисбаланс микробиомов, постоянное образование слизи, структурное повреждение и использование ингаляционных ГКС [3].

Пациенты с ХОБЛ, наряду с пациентами с АГ, СД, другими ССЗ и цереброваскулярными заболеваниями, относятся к уязвимой группе населения во время пандемии COVID-19 [4].
У пациентов с ХОБЛ и курильщиков в дыхательных путях повышены уровни АПФ2, являющегося рецептором проникновения вируса [5]. В метаанализе 11 исследований [6] показано, что у этой категории риск тяжелого течения COVID-19 составляет 4,38 (95\% доверительный интервал (ДИ): 2,34$8,20)$.

В другом метаанализе [3], включавшем 7 исследований и в общей сложности 1592 пациента с COVID-19, также подчеркивается, что ХОБЛ достоверно связана с тяжелым течением COVID-19 (отношение рисков (ОР)=5,69; 95\% ДИ: 2,49-13,00). Пациенты с ХОБЛ с большей вероятностью нуждаются в поддержке отделения интенсивной терапии и имеют более высокую смертность по сравнению с другими группами пациентов.

Прогностически важным аспектом может быть прекращение курения у пациентов, инфицированHыx SARS-CoV-2 [7].

Из-за длительного инкубационного периода, скрытого начала и разнообразных и нетипичных симптомов новой коронарной пневмонии, когда она возникает у пациентов с ХОБЛ, клинические проявления могут быть более атипичными и могут быть перепутаны с существующими симптомами ХОБЛ. Пациенты с ХОБЛ имеют сниженную базовую функцию легких и низкую толерантность к гипоксии [8].

Следует отметить, что обострения у пациентов с ХОБЛ легко принять за новую коронарную пневмонию, госпитализировать пациента и провести ненужные обследования. Обострение ХОБЛ также может вызывать повышение температуры, кашель и одышку, оно может сопровождаться такими симптомами, как слабость конечностей и стеснение в груди. В целом, обострение у пациентов с ХОБЛ проявляется быстрым нарастанием респираторных симптомов, таких как кашель, мокрота и одышка, в краткосрочной перспективе. В ранней стадии новой коронарной пневмонии часто преобладают системные симптомы, такие как лихорадка и усталость. Это переносится пациентами легче, но затрудненное дыхание может быстро увеличиться через 6-7 дней.

$\mathrm{K}$ настоящему времени опубликованы рекомендации Китайского торакального общества/ Китайской ассоциации врачей-терапевтов [8] и Канадского торакального общества [9] по оптимизации курации пациентов с ХОБЛ во время пандемии COVID-19.

K общим рекомендациям для всех пациентов с ХОБЛ относятся рекомендации по режиму: как можно больше оставаться дома, включая работу на дому, если это возможно. Если пациенты должны покинуть дом, им рекомендуется следовать действующим местным, национальным и глобальным рекомендациям по общественному здравоохранению 
в отношении показаний для физического дистанцирования и изоляции [9].

Пациенты с ХОБЛ могут носить одноразовые медицинские маски или хирургические маски и стараться избегать ношения масок № 95, которые могут привести к усилению затруднений дыхания и задержке углекислого газа у пациентов с ХОБЛ [8]. Необходимо соблюдать гигиену рук.

При нахождении дома необходимо регулярное проветривание помещения, при домашней дезинфекции требуется особая осторожность с хлорсодержащими дезсредствами, которые могут вызвать раздражение дыхательных путей и бронхоспазм [8].

Пациенту рекомендуется мониторировать симптомы заболевания: в т.ч. кашель, мокроту, проблемы с дыханием, температуру тела, усталость, ограничение двигательной активности и нарушения сна.

В период пандемии пациентам с ХОБЛ рекомендуется продолжать обычную поддерживающую терапию и лечение обострения ХОБЛ в соответствии с текущими рекомендациями по лечению [1].

На сегодняшний день нет данных, что применение ингаляционных ГКС и бронходилататоров повышает потребность в госпитализации, интубации для искусственной вентиляции легких или смерти $[8,9]$. Существуют предварительные доказательства того, что циклесонид может подавлять вирусную репликацию SARS-CoV-2 in vitro с эффективностью, аналогичной лопинавиру и рассматривается в качестве кандидата на лечение COVID-19 [10].

Однако не рекомендуется использовать небулайзер во время пандемии $[9,11]$, поскольку существует повышенный риск аэрозольного распространения вирусных частиц. Пациентам следует использовать различные дозирующие ингаляторы для введения всех препаратов для лечения ХОБЛ дома, а также в медицинских учреждениях и домах престарелых. Пациенты, которые уже используют небулайзеры в домашних условиях, должны продолжать делать это, пока они не смогут перейти на альтерна-

\section{Литература/References}

1. Global Strategy for the Diagnosis, Management, and Prevention of Chronic Obstructive Pulmonary Diseas (2020 REPORT). https:// goldcopd.org/gold-reports/.

2. Adeloye D, Chua S, Lee C, et al; Global Health Epidemiology Reference Group (GHERG). Global and regional estimates of COPD prevalence: Systematic review and meta-analysis. J Glob Health. 2015;5(2):020415. doi:10.7189/jogh.05-020415.

3. Lippi G, Henry BM. Chronic obstructive pulmonary disease is associated with severe coronavirus disease 2019 (COVID-19). Respir Med. 2020;167:105941. doi:10.1016/j. rmed.2020.105941.

4. Wang B, Li R, Lu Z, Huang Y. Does comorbidity increase the risk of patients with COVID-19: evidence from meta-analysis. Aging (Albany NY). 2020;12(7):6049-57. doi:10.18632/aging.103000.

5. Leung JM, Yang CX, Tam A, et al. ACE-2 expression in the small airway epithelia of smokers and COPD patients: тивные методы доставки. Тем не менее, они должны рассмотреть возможность распыления своих лекарств в отдельной комнате и выполнять другие рекомендации по инфекционному контролю [9].

Остается неясным вопрос, связанный с приемом пациентами системных ГКС. Их применение по показаниям коротким курсом (5-10 дней) может снизить потребность пациента в использовании неотложной помощи, что компенсирует низкий риск того, что ГКС могут продлить репликацию вируса $[9,12]$.

Пациенты, которые находятся на домашней кислородотерапии с помощью специальных аппаратов, должны продолжать использовать метод оксигенотерапии, как это предписано. Они должны следовать инструкциям производителя по чистке и обслуживанию своего оборудования. Если пациенту пришлось увеличить скорость потока, он должен сообщить об этом врачу и/или куратору [8].

Существует достаточное теоретическое обоснование, чтобы опасаться, что часть пациентов с ХОБЛ приобретет новые сопутствующие заболевания или ухудшение предыдущих (с особыми последствиями в сердечно-сосудистой сфере) и то, что COVID-19 может оказывать влияние на функцию легких неопределенного диапазона [12].

\section{Резюме:}

1. ХОБЛ связана с повышенным риском заболеваемости и смертности при внебольничной пневмонии.

2. Пациенты с ХОБЛ и курильщики относятся к группе риска по развитию COVID-19.

3. Наличие у пациента ХОБЛ более чем в 5 раз увеличивает риск развития тяжелого течения COVID-19.

4. В период пандемии пациентам с ХОБЛ рекомендуется продолжать обычную поддерживающую терапию и лечение обострения ХОБЛ в соответствии с текущими рекомендациями по лечению.

5. Не рекомендуется использовать небулайзер во время пандемии, поскольку существует повышенный риск аэрозольного распространения вирусных частиц. Предпочтение следует отдавать различным дозирующим ингаляторам.

implications for COVID-19. Eur Respir J. 2020;55(5):2000688. doi:10.1183/13993003.00688-2020.

6. Zhao Q, Meng M, Kumar R, et al. The impact of COPD and smoking history on the severity of COVID-19: A systemic review and metaanalysis. J Med Virol. 2020. doi:10.1002/jmv.25889.

7. Gonçalves JMF, Golpe R, García-Talavera I. Chronic obstructive pulmonary disease and SARS-CoV-2 infection. What do we know so far?.Arch Bronconeumol. 2020. doi:10.1016/j. arbres.2020.04.016.

8. Chronic Obstructive Pulmonary Disease Group of Chinese Thoracic Society; Chronic Obstructive Pulmonary Disease Committee of Chinese Association of Chest Physician. Medical Management and Prevention Instruction of Chronic Obstructive Pulmonary Disease During the Coronavirus Disease 2019 Epidemic. Zhonghua Jie He He Hu Xi Za Zhi. 2020;43(5):421-6. doi:10.3760/cma.j.cn112147-20200227-00201. 
9. Bhutani M, Hernandez P, Bourbeau J, et al. KEY HIGHLIGHTS of the Canadian Thoracic Society's Position Statement on the Optimization of Chronic Obstructive Pulmonary Disease Management during the COVID-19 Pandemic. Chest. 2020:S00123692(20)31456-2. doi:10.1016/j.chest.2020.05.530.

10. Matsuyama S, Kawase $M, N a o N$, et al. The inhaled corticosteroid ciclesonide blocks coronavirus RNA replication by targeting viral NSP15. bioRxiv. 2020.03.11.987016. doi:10.1101/2020.03.11.987016.

11. Temporary guidelines "Prevention, diagnosis and treatment of new coronavirus infection (COVID-19). Version 7" (approved

Раздел 3. Заболевания эндокринной системы 3.1. Сахарный диабет

СД - это группа метаболических (обменных) заболеваний, характеризующихся хронической гипергликемией, которая является результатом нарушения секреции инсулина, действия инсулина или обоих этих факторов. Хроническая гипергликемия при СД сопровождается повреждением, дисфункцией и недостаточностью различных органов, особенно глаз, почек, нервов, сердца и кровеносных сосудов.

По последним данным, численность больных СД в мире за последние 10 лет увеличилась более, чем в 2 раза, и к концу 2017г превысила 425 млн человек. Согласно прогнозам Международной диабетической федерации (International Diabetes $\mathrm{Fe}$ deration, IDF) к 2045г СД будет страдать 629 млн человек. В Российской Федерации (РФ), как и во всех странах мира, отмечается значимый рост распространенности СД.

По данным федерального регистра СД в РФ на окончание 2018г состояло на диспансерном учете 4584575 человек (3,1\% населения), из них: $92 \%$ (4238503) - СД 2 типа, 6\% (256202) - СД 1 типа и $2 \%$ (89870) - другие типы СД, в т.ч. 8006 женщин с гестационным СД. Однако эти данные недооценивают реальное количество пациентов, поскольку учитывают только выявленные и зарегистрированные случаи заболевания. Так, результаты масштабного российского эпидемиологического исследования (NATION) подтверждают, что диагностируется лишь 54\% случаев СД 2 типа [1].

СД является одним из наиболее важных сопутствующих заболеваний, связанных с тяжестью всех трех известных патогенных коронавирусных инфекций человека, включая COVID-19. Международная группа экспертов в области диабета и эндокринологии отмечает, что в зависимости от глобального региона, 20-50\% пациентов с COVID-19 имели СД 2 типа [2]. В настоящее время нет доказательств у пациентов с СД 1 типа о повышенном риске развития COVID-19.

СД 2 типа является значимым фактором риска развития тяжелой пневмонии, ОРДС взрослых и септического течения вирусной инфекции, ассо- by the Ministry of health of the Russian Federation on June 03, 2020). (In Russ.) Временные методические рекомендации "Профилактика, диагностика и лечение новой коронавирусной инфекции (COVID-19). Версия 7" (утв. Министерством здравоохранения РФ 03 июня 2020 г.) https://www.rosminzdrav. ru/news/2020/06/03/14109-minzdrav-rossii-utverdil-7-versiyumetodicheskih-rekomendatsiy-po-lecheniyu-covid-19

12. Tal-Singer R, Crapo JD. COPD at the Time of COVID-19: A COPD Foundation Perspective. Chronic Obstr Pulm Dis. 2020;7(2):7375. doi:10.15326/jcopdf.7.2.2020.0149.

циированного с развитием полиорганной недостаточности, повышением риска осложнений и смерти $[2,3]$. Риск неблагоприятного исхода возрастает при увеличении индекса массы тела $>40$ кг/ $\mathrm{M}^{2}$ [4].

К общим рекомендациям для всех пациентов с СД 2 типа относятся рекомендации по режиму: как можно больше оставаться дома, включая работу на дому, если это возможно. Если пациенты должны покинуть дом, им рекомендуется следовать действующим местным, национальным и глобальным рекомендациям по общественному здравоохранению в отношении показаний для физического дистанцирования и изоляции, чтобы избежать инфицирования COVID-19.

В качестве специфической профилактики рекомендовано применение препаратов альфа-интерферона [3].

У пациентов с СД нарушен не только углеводный обмен, но и другие виды метаболизма, что приводит к развитию осложнений и коморбидных состояний и заболеваний. Лечение у больных СД 1 и 2 типа дислипидемий, АГ, нефропатии, нейропатии, ретинопатии проводится по принципам, предусмотренным соответствующими рекомендациями [1]. Витамины группы В широко используются при лечении диабетической нейропатии. Считается целесообразным назначение пациентам с СД “антиоксидантных комплексов”, содержащих микроэлементы (например, селен, цинк и др.) и витамины А, E, C [4].

Важное место в период пандемии для пациентов с СД 1 и 2 типа занимает осуществление регулярного мониторинга глюкозы плазмы [5-7]. В период пандемии пациенту с СД желательно сформировать определенный запас лекарственных препаратов (инсулина для пациентов с СД 1 типа), расходных материалов для глюкометра, иметь в наличии набор для лечения гипогликемии (плюс глюкагон для внутримышечного введения), вести дневник учета уровня глюкозы крови, приема лекарственных препаратов, температуры, массы тела $[6,7]$.

При легком течении COVID-19 пациент с СД изолируется и продолжает лечение амбулаторно. Рекомендуется учащение контроля гликемии 
каждые 4-6 ч с расширением питьевого режима до 2-3 л/сут. с учетом сопутствующих заболеваний. Необходимо продолжить текущую сахароснижающую терапию [3].

При повышении гликемии целесообразно рассмотреть вопрос о госпитализации, усилить терапию СД. При гликемии выше 13-15 ммоль/л надо оценить уровень кетонов в моче и добавить инсулин-изофан человеческий генно-инженерный инсулин или аналог инсулина длительного действия [3].

Среднетяжелое и тяжелое течение COVID-19 у пациентов с СД 1 и 2 типа являются показаниями к госпитализации [3].

При среднетяжелом течении COVID-19 и появлении респираторных симптомов у пациентов с СД 2 типа необходимо отменить прием метформина, агонистов рецепторов ГПП-1, ингибиторов натрий-глюкозного котранспортера 2 типа, препаратов сульфонилмочевины [3]. Лактоацидоз, связанный с метформином (чаще развивающийся при высокой температуре), или гипергликемический диабетический кетоацидоз (чаще развивающийся у лиц с обезвоживанием, обусловленном диареей и рвотой), связанный с ингибиторами натрий-глюкозного котранспортера 2 типа, являются редкими случаями, но отмена этих препаратов позволяет уменьшить риск острой метаболической декомпенсации [2, 8].

Контроль гликемии следует проводить каждые 3-4 ч, контроль кетонов в моче 1-2 раза/сут., проводится и оценка содержания лактата [3]. При гликемии выше 15,0 ммоль/л в соответствии с российскими рекомендациями показано назначение инсулина короткого типа действия или базис-болюсной инсулинотерапии [3]. В британских рекомендациях отмечается, что начало инсулинотерапии у пациентов с СД 2 типа может быть необходимым и при более низком уровне глюкозы 12,0 ммоль/л [6].

У пациентов с СД 1 типа следует проводить контроль глюкозы плазмы (7-8 раз/сут.) и кетоновых тел в моче. Если кетоновые тела в моче отсутствуют, необходимо увеличить дозу инсулина ультракороткого/короткого действия во время плановых инъекций перед едой на 5-10\% от обычной суммарной суточной дозы всех инсулинов, а также делать это в виде внеплановых инъекций. Не рекомендуется делать инъекции чаще, чем 1 раз в 2-3 ч (для инсулина ультракороткого действия) или 3-4 ч (для инсулина короткого действия), следует сначала оценить действие предыдущей дозы [9]. Лечение диабетического кетоацидоза проводится в соответствии с утвержденными рекомендациями $[1,9]$.

Тяжелое течение COVID-19 характеризуется прогрессированием дыхательной и полиорганной недостаточности.

Целевая гликемия определяется тяжестью состояния пациента и течением заболевания. Необходимо отменить все сахароснижающие препараты кроме инсулина и назначить непрерывное внутривенное введение инсулина короткого действия с помощью инфузомата. Контроль гликемии следует проводить каждый час при гликемии выше 13,0 ммоль/л или каждые 3 ч при гликемии ниже 13,0 ммоль/л для коррекции скорости введения инсулина, контроль содержания кетонов в моче и лактата в крови проводится 2 раза/сут. [3, 9].

В российских рекомендациях [3] выделены особенности лечения COVID-19 у пациентов с СД:

1. Пациенты с СД находятся в группе высокого риска присоединения бактериальной инфекции. При среднетяжелом и тяжелом течении рекомендуется в упредительном режиме назначение антибактериальной терапии в сочетании с этиотропной терапией COVID-19.

2. При назначении комбинированной терапии ингибиторами протеаз вируса иммунодефицита человека и ГКС следует ожидать повышения гликемии. Необходимо проводить контроль каждые 3 ч, увеличить скорость подачи инсулина по данным контроля гликемии (доза инсулина может быть увеличена в 2-3 раза в сравнении с исходной).

3. Для пациентов с СД характерно более быстрое развитие ОРДС. Обосновано ранее упреждающее назначение моноклональных антител для терапии “цитокинового шторма". Необходимо проводить мониторинг клинических маркеров интерлейкинового воспаления для своевременного назначения терапии.

Имеется четкая связь между СД, прежде всего СД 2 типа, и СС3, которые у пациентов с СД 2 типа встречаются в 2-5 раз чаще, чем у лиц без диабета. Часто СС3, и именно сердечно-сосудистые исходы, являются главной причиной смертности этих пациентов как у мужчин, так и у женщин.

При наличии у пациента с СД АГ рекомендуется продолжать текущую антигипертензивную терапию, включая иАПФ и БРА $[2,10]$.

Рекомендуется контролировать липидный профиль у всех пациентов с COVID-19, прием статинов не следует прекращать из-за долгосрочных преимуществ [2].

Таким образом, СД 2 типа следует рассматривать как фактор риска быстрого прогрессирования и плохого прогноза COVID-19. Более интенсивное внимание следует уделять пациентам с СД, в случае быстрого ухудшения контроля гликемии и общего состояния.

По окончанию пандемии COVID-19 не исключено развитие нарушений углеводного обмена у лиц без СД, перенесших COVID-19, поскольку при продолжительном наблюдении у $60 \%$ пациентов, выздоровевших после тяжелого острого респираторного синдрома, вызванного предшествующим коронавирусом SARS-CoV, отмечены нарушения метаболизма глюкозы [11]. 
Резюме:

1. СД 2 типа связан с повышенным риском заболеваемости, быстрого прогрессирования и неблагоприятного прогноза при COVID-19.

2. В период пандемии пациентам с СД необходим регулярный мониторинг глюкозы плазмы. Рекомендуется продолжать текущую сахароснижающую терапию и терапию коморбидных заболеваний и состояний, в первую очередь лечение АГ и дислипидемии.

3. При легком течении COVID-19 пациент лечится амбулаторно и продолжает текущую сахароснижающую терапию.

4. Среднетяжелое и тяжелое течение COVID-19 у пациентов с СД являются показаниями к госпитализации.

5. При среднетяжелом течении COVID-19 и наличии респираторных симптомов необходимо у пациентов СД 2 типа отменить прием метформина, агонистов рецепторов ГПП-1, ингибиторов натрий-глюкозного котранспортера 2 типа, препаратов сульфонилмочевины с целью снижения риска метаболической декомпенсации.

6. При гликемии выше 15,0 ммоль/л показано назначение инсулина короткого типа действия или базис-болюсной инсулинотерапии.

7. При тяжелом течении COVID-19 необходимо отменить все сахароснижающие препараты кроме инсулина.

8. У лиц без СД, перенесших COVID-19, возможно развитие нарушений метаболизма глюкозы.

\section{Литература/References}

1. Algorithms for specialized medical care for patients with diabetes. Edited By I.I. Dedov, M.V. Shestakova, and A. Yu. Mayorov. 9th issue (expanded). Moscow; 2019. (In Russ.) Алгоритмы специализированной медицинской помощи больным сахарным диабетом. Под редакцией И.И. Дедова, М.В. Шестаковой, А. Ю. Майорова. 9-й выпуск (дополненный). Сахарный диабет.2019;22(S1). doi:10.14341/DM221S1

2. Bornstein SR, Rubino F, Khunti K, et al. Practical recommendations for the management of diabetes in patients with COVID-19. Lancet Diabetes Endocrinol. 2020;8(6):546-50. doi:10.1016/S22138587(20)30152-2.

3. Temporary guidelines for Prevention, diagnosis and treatment of new coronavirus infection (COVID-19) version 7 (03.06.2020) of the Ministry of health of the Russian Federation. (In Russ.) Временные методические рекомендации Профилактика, диагностика и лечение новой коронавирусной инфекции (COVID-19) версия 7 (03.06.2020) Министерства здравоохранения Российской Федерации. https://www.rosminzdrav. ru/news/2020/06/03/14109-minzdrav-rossii-utverdil-7-versiyumetodicheskih-rekomendatsiy-po-lecheniyu-covid-19

4. Trukhan DI, Viktorova IA. Nephrology. Endocrinology. Hematology. Saint Petersburg: Spetslit, 2017. 253 р. (In Russ.) Трухан Д.И., Викторова И. А., Нефрология. Эндокринология. Гематология. СПб.: СпецЛит, 2017. 253 с.

5. Zhou F, Yu T, Du R, et al. Clinical course and risk factors for mortality of adult inpatients with COVID-19 in Wuhan, China: a retrospective cohort study. Lancet. 2020;395(10229):1054-62. doi:10.1016/S0140-6736(20)30566-3.

6. Sinclair A, Dhatariya K, Burr O, et al. Guidelines for the management of diabetes in care homes during the Covid-19 pandemic. Diabet Med. 2020. doi:10.1111/dme.14317.

7. Rayman G, Lumb A, Kennon B, et al. New Guidance on Managing Inpatient Hyperglycaemia during the COVID-19 Pandemic. Diabet Med. 2020 May 17. doi:10.1111/dme.14327.

8. Rayman G, Lumb A, Kennon B, et al. Guidance on the management of Diabetic Ketoacidosis in the exceptional circumstances of the COVID-19 pandemic. Diabet Med. 2020. doi: $10.1111 /$ dme.14328.

9. Endocrinopathy and COVID-19. Emergency conditions, their prevention and treatment. Prepared by NMIC endocrinology of the Ministry of health of Russia 21.04.2020. (In Russ.) Эндокринопатии и COVID-19. Неотложные состояния, их профилактика и лечение. Подготовлено ФГБу "НМИЦ эндокринологии" Минздрава России 21.04.2020. http:// edu.rosminzdrav.ru/fileadmin/user_upload/specialists/COVID19/dop-materials/22.04.2020/EHndokrinopatii_i_COVID19 21.04.2020.pdf

10. Fulchand S. Covid-19 and Cardiovascular Disease. BMJ. 2020 May 20;369:m1997. doi:10.1136/bmj.m1997.

11. Wu Q, Zhou L, Sun X, et al. Altered lipid metabolism in recovered SARS patients twelve years after infection. Sci Rep. 2017;7:9110. doi: 10.1038/s41598-017-09536-z.

лечебно-диагностические подходы в отношении больных такой категории.

\section{1. Гастроэнтерологические проявления COVID-19}

Эпителиоциты слизистой оболочки (СО) полости рта, пищевода, желудка, тонкой и толстой кишки, также как и эпителий верхних дыхательных путей экспрессируют рецепторы АПФ2 и являются входными воротами возбудителя. На начальном этапе заражения проникновение коронавируса SARS-CoV-2 в клетки-мишени может вызывать проявления катарального гастроэнтероколита. Кроме выраженной экспрессии рецепторов АПФ2 клетками эпителия СО и холангиоцитами, поражению органов пищеварения также способствует, 
обусловленная патогеном повышенная проницаемость СО ЖКТ, цитокиновая агрессия и системное воспаление, расстройства микроциркуляции, а также нарушение структуры и функции микробнотканевого комплекса. В формировании патологических изменений СО и повреждения печени большое значение имеет агрессивная многокомпонентная терапии (НПВП, антибактериальные и противовирусные препараты), проводимая при COVID-19 [1-5].

Анализ данных 95 случаев инфекции, вызванной SARS-CoV-2, показал, что в 58 случаях наблюдались симптомы поражения ЖКТ, из которых у 11 (11,6\%) имели место при поступлении, а 47 (49,5\%) проявились во время госпитализации [6].

По результатам систематического обзора и метаанализа, включающего 6686 пациентов с COVID-19 в 35 исследованиях, общая распространенность гастроинтестинальных симптомов составила $15 \%$. Установлено, что наиболее частыми симптомами поражения ЖКТ являются тошнота, рвота, диарея и потеря аппетита. Фекально-оральный механизм заражения подтверждает тот факт, что у $10 \%$ пациентов с COVID-19 отмечались только желудочно-кишечные симптомы без респираторных нарушений, а у части больных возникновение диспепсического синдрома предшествовало появлению признаков поражения дыхательных путей. Нарушения печеночных показателей в виде транзиторного подъема активности трансаминаз, уровня билирубина выявлены у 19\% пациентов (12 исследований, 1267 пациентов) [2].

У пациентов с тяжелым течением COVID-19 описаны случаи развития эрозивно-язвенного поражения ЖКТ, осложненные кровотечением [6]. У половины больных с признаками поражения ЖКТ в стуле обнаруживалась рибонуклеиновая кислота (РНK) коронавируса SARS-CoV-2 [7].

Тяжелое течение COVID-19, в отличие от еe нетяжелых форм, ассоциировалось с более высокими показателями частоты и выраженности гастроинтестинальных симптомов и нарушений печеночных показателей. Наличие признаков повреждения органов ЖКТ было связано с задержкой установки диагноза COVID-19, а течение заболевания сопряжено с большей частотой осложнений [2, 8-12].

При появлении диспепсического и болевого абдоминального синдромов у пациента с хроническим заболеванием ЖКТ в анамнезе в период пандемии COVID-19 необходимо проводить дифференциальную диагностику между обострением заболевания, гастроинтестинальными проявлениями COVID-19 и осложнениями терапии COVID-19.

Если у пациента с температурой тела выше $37,5^{\circ} \mathrm{C}$ выявляется рвота, диарея, при отсутствии других известных причин этих симптомов (хрони- ческое заболевание ЖКТ ранее не имело таких проявлений) в соответствии с Временными рекомендациями Минздрава РФ случай рассматривается как подозрительный на COVID-19, требующий проведения необходимых лечебно-диагностических и противоэпидемических мероприятий [1]. В пользу COVID-19, в отличие от обострения хронического заболевания ЖКТ, может свидетельствовать характерный эпидемиологический анамнез, более быстрое возникновение клинических проявлений, последующее (или одновременное) развитие респираторных симптомов, аносмии, лихорадки, общей слабости, интоксикации, положительный анализ на PHK (иммуноглобулин M) SARS-CoV-2. Также на фоне тяжелого течения и агрессивной терапии COVID-19 вполне возможно обострение имеющегося хронического заболевания ЖКТ.

По данным систематического обзора и метаанализа, общая распространенность сопутствующих заболеваний органов пищеварения на момент диагностики COVID-19 составляла всего 4\% [2].

Повреждение ЖКТ коронавирусом SARS-CoV-2 закономерно приводит к нарушению микробно-тканевого комплекса (усилению имеющихся нарушений) и повышению проницаемости барьера СО ЖКТ с формированием и прогрессированием таких патофизиологических феноменов как хроническое системное воспаление и цитокиновая агрессия, инсулинорезистентность, эндотелиальная дисфункция, которые с одной стороны определяют соматический статус пациента, в т.ч. и больного с COVID-19, a с другой - оказывают влияние на тяжесть инфекции и возможность развития ее осложнений. В свою очередь, изменение состава и функции микробиома и вирома кишечника приводит к нарушению взаимодействия оси “кишечник-легкие" и изменению функции легочного барьера [3, 4, 13]. Данные о влиянии тяжелых и осложнённых хронических заболеваний ЖKT на течение COVID-19 представлены в соответствующих подразделах.

Обследование пациентов с COVID-19 (подозрением на нее), с учетом возможностей диагностики в медицинском учреждении, должно включать:

- уточнение жалоб со стороны органов пищеварения: анорексия, нарушения стула, метеоризм, тошнота, рвота, боль в животе;

- физикальное обследование с подробным исследованием органов брюшной полости (осмотр живота, пальпация, перкуссия) с определением зон урчания, болезненности при глубокой пальпации, размеров печени и селезенки по Курлову. Выяснение характеристик стула: частота за сутки, объем, форма (консистенция), цвет, запах, наличие патологических примесей;

- дополнительное лабораторное исследование: определение активности аланинаминотрансферазы (АЛТ), аспартатаминотрансферазы, гамма- 
глутамиламинотрансферазы, щелочной фосфатазы, содержания билирубина;

- ультразвуковое исследование (УЗИ) органов брюшной полости - при наличии клинических и лабораторных признаков поражения печени;

- эндоскопическое исследование - по экстренным показаниям (при многократной рвоте, рвоте с кровью, подозрении на желудочно-кишечное кровотечении, тяжелой дисфагии, интенсивной боли в животе).

С учетом локальных ресурсов целесообразно определение коронавируса SARS-CoV-2 в пробах кала, как для установления диагноза, так и для мониторинга вирусного клиренса.

В период пандемии COVID-19 лечение хронических заболеваний ЖКТ проводится на основе действующих клиническими рекомендациями. Особенности терапевтических подходов в отношении ведения пациентов с кислотозависимыми заболеваниями, хроническими заболеваниями печени, кишечника, ХП, не имеющих COVID-19 и на фоне развившейся COVID-19, представлены в соответствующих подразделах.

Общими рекомендациями, направленными на снижение рисков инфицирования коронавирусом SARS-COV-2 и тяжелого течения возникшей инфекции, являются укрепления иммунной резистентности СО ЖКТ и дыхательного тракта, нормализация микробно-тканевого комплекса и взаимодействия оси “кишечник-легкие", восстановление защитного барьера СО. Для поддержания баланса кишечной микрофлоры используются ее модуляторов (пребиотики, пробиотики) и нутритивная поддержка.

В настоящее время способность устранять повышенную проницаемость СО ЖКТ доказана только для одной молекулы - регулятора синтеза простагландинов Е2 и I2 - ребамипида. Его действие реализуется на трех структурных уровнях (преэпителиальный, эпителиальный и субэпителиальный) на всем протяжении ЖКТ. Основными компонентами позитивного действия препарата являются восстановление качественного (мукопротеины и альфа-дефензины) и количественного состава слоя слизи, повышение продукции белков плотных контактов, гликозамингликанов, нейтрализация свободных радикалов, стимуляция ангиогенеза. Влияние ребамипида на регуляцию (разрешение) воспаления осушествляется путем уменьшения адгезии нейтрофилов к эпителиальным клеткам, снижения активности нейтрофилов и макрофагов, снижения уровня воспалительных цитокинов (IL-8, IL-1, IL-10, TNF- $\alpha$ ) [3, 14, 15].

Назначение ребамипида существенно повышает эффективность лечения пациентов с гастроэзофагеальной рефлюксной болезнью, НПВП-индуцированной гастропатией и энтеропатией, хроническим гастритом, язвенной болезнью и другими заболеваниями. Широкое использование реба- мипида в мировой практике для восстановления и защиты СО ЖКТ в условиях воздействия эндогенных и экзогенных факторов агрессии особенно актуально в комплексных лечебных подходах при COVID-19 [16].

Большая доказательная база, свидетельствующая об эффективности препарата в лечении различных заболеваний ЖКТ, нашла отражение во включении ребамипида в клинические рекомендации российских и международных врачебных ассоциаций [17-22].

Ребамипид восстанавливает барьерные функции СО, что включает себя нормализацию количественного и качественного состава слизи как ЖКТ, так и дыхательных путей, обладает потенциалом для уменьшения интенсивности воспалительных процессов в лёгких путем ингибирования активации эпидермального фактора роста и снижения содержания провоспалительных цитокинов (IL-1, IL-6, IL-8, MCP-1, MIP-1, TNF-a), уровень которых повышен при COVID-19, а также способствует сохранению альвеолярного и мышечных слоёв [3, 23-25].

Также имеются данные о способности ребамипида восстанавливать саливацию, что особенно актуально, учитывая значимость фекально-орального пути заражения коронавирусной инфекцией [26].

В целом, повышение защитных свойств барьера СО с помощью ребамипида позволяет достигнуть и поддерживать у пациента клиническую ремиссию гастроэнтерологического заболевания, а также, в силу влияния молекулы на содержание целого рядя цитокинов, может оказать влияние на снижение риска тяжелого течения COVID-19 в случае его инфицирования.

\section{Резюме:}

1. У пациентов с COVID-19 с высокой частотой выявляются гастроинтестинальные симптомы: диарея, тошнота, рвота, анорексия.

2. Увеличение частоты и выраженности гастроинтестинальных симптомов и нарушений печеночных показателей ассоциируется с более тяжелым течением COVID-19 и более частым развитием ее осложнений.

3. Повреждение CO ЖКТ коронавирусом SARS-CoV-2 может приводить к нарушению (потенцировать имеющиеся изменения) микробно-тканевого комплекса и повышению проницаемости барьера СО ЖКТ с формированием и прогрессированием патофизиологических феноменов (хроническое системное воспаление и цитокиновая агрессия, инсулинорезистентность, эндотелиальная дисфункция), определяющих соматический статус пациента и влияющих на тяжесть инфекции и возможность развития ее осложнений.

4. Наличие и тяжесть хронических заболеваний органов пищеварения могут значимо влиять на течение COVID-19 и на прогноз пациента в целом.

5. Ребамипид оказывает положительное влияние на защитный барьер СО ЖКТ и других органов, реализуя выраженное цитопротективное действие, что позволяет применять его для лечения и профилактики заболеваний ЖКТ. Препарат перспективен к использованию в комплексной терапии и профилактике COVID-19. 


\section{2. Кислотозависимые заболевания ЖКТ}

Актуальность гастроэзофагеальной рефлюксной болезни (ГЭРБ) обусловлена ее высокой распространенностью, широким спектром клинических проявлений, большой частотой диагностических ошибок и опасностью осложнений.

ГЭРБ - хроническое рецидивирующее заболевание, обусловленное периодическими забросами желудочного и/или дуоденального содержимого в пищевод вследствие нарушения моторно-эвакуаторной функции эзофагогастродуоденальной зоны, с развитием повреждения СО дистальной части пищевода (дистрофии эпителия, катарального или эрозивно-язвенного эзофагита, в ряде случаев метаплазии), характеризующееся пищеводными и внепищеводными клиническими проявлениями, ухудшающими качество жизни пациентов, а также возможным развитием осложнений [3, 17, 27].

Рекомендации по терапии пациентов, не имеющих COVID-19

В период пандемии лечебно-диагностические мероприятия в отношении пациентов с ГЭРБ, не инфицированных COVID-19, в целом проводятся в соответствии с действующими клиническими рекомендациями $[17,27]$ с учетом ряда эпидемиологических и клинических аспектов.

Первичная диагностика ГЭРБ проводится на амбулаторном этапе, при отсутствии “симптомов тревоги” все дополнительные лабораторно-инструментальные исследования планируются на постпандемический период. Повторные визиты целесообразно проводить с использованием дистанционных средств коммуникации, телемедицинских консультаций.

С учетом реорганизации сил и средств здравоохранения для оказания помощи больным COVID19 стационарное дообследование пациентов с рефрактерной ГЭРБ (отсутствие клинической и эндоскопической ремиссии нафоне 4-8 нед. полноценной терапии) может быть отложено или проведено амбулаторно. При возникновении осложнений, требующих оказания неотложной помощи в стационаре, проводится весь необходимый комплекс лечебнодиагностических мероприятий согласно правилам маршрутизации пациентов без COVID-19, нуждающихся в экстренной хирургической помощи [1].

Лечение пациентов с ГЭРБ включает рекомендации по питанию и изменению образа жизни, медикаментозную терапию и предусматривает, прежде всего, нормализацию структуры и функции СО пищевода, что, как следствие, способствует устранению гиперчувствительности и восстановлению моторики.

В качестве препаратов, снижающих агрессивное воздействие соляной кислоты, применяются ингибиторы протонной помпы (ИПП), которые обеспечивают у части пациентов купирование симптомов и их контроль, а также предупреждение развития осложнений. Необходимо использовать препараты, обладающие минимальным риском межлекарственных взаимодействий (пантопразол 40 мг/сут., рабепразол 20 мг/сут.). Рекомендованная продолжительность основного курса ИПП составляет 8 нед. (при наличии внепищеводных синдромов, упорном течении - 12 нед.), дальнейшая поддерживаюшая противорецидивная терапия ИПП в половинной дозе до 6 мес.

В этой связи приобретает актуальность проблема снижения мощности защитного кислотного барьера желудка и потенциального увеличения риска фекально-орального заражения SARS-COV-2. В настоящее время данные, свидетельствующие о повышенном риске заражения COVID-19 на фоне приёма ИПП, или ассоциированного с ними риска осложнений у заразившихся пациентов, имеют характер отдельных клинических наблюдений или экспериментальных исследований. По данным ретроспективного общенационального когортного исследования, включившего 8309 историй болезни пациентов после ишемического инсульта, кислотосупрессивная терапия с использованием ИПП и Н2-гистаминовых антагонистов связана с повышенным риском развития постинсультной пневмонии, в то время как при лечении мукопротекторными средствами (ребамипидом) такая связь отсутствовала [28]. Также имеются экспериментальные данные, демонстрирующие связь применения ИПП с повышением титра коронавируса SARS-2 в лёгких на фоне кислотосупрессивной терапии [29]. В связи с этим крайне важным представляется разъяснение необходимости тщательного соблюдения противоэпидемических мероприятий всем пациентам, получающим кислотосупрессивную терапию.

В комплексной терапии дополнительно могут использоваться невсасывающиеся антациды и адсорбенты (с учетом сорбционного эффекта принимать отдельно от других лекарственных препаратов). Также используются средства коррекции микробнотканевого комплекса кишечника (пребиотики, метабиотики).

В качестве препаратов для купирования симптоматики применяются прокинетики - лучшим профилем безопасности обладает итоприд (150 мг/сут. до 4 нед.).

Диагностику и эрадикацию инфекции H. pylori у пациентов с ГЭРБ, длительно получающих ИПП, целесообразно отложить на постпандемический период, т.к. прием антибиотиков может существенно изменить иммунную резистентность организма и способствовать формированию множественной антибиотикорезистентности бактериальной флоры.

У пациентов, страдающих ГЭРБ с эрозивноязвенным эзофагитом, внепищеводными проявле- 
ниями со стороны дыхательной системы, осложненными формами заболевания, а также длительно применяющих препараты с выраженным кислотосупрессивным эффектом можно предполагать более тяжелое течение COVID-19. В свою очередь, мукопротекторные препараты, в частности, ребамипид, продемонстрировали способность восстанавливать барьер СО ЖКТ и ротовой полости: нормализовать слюноотделение, а также состав слизи [3, 23-25], что создает определенные приоритеты для профилактики фекально-орального инфицирования.

ГЭРБ характеризуется существенной коморбидностью, включающей как гастроэнтерологическую, так и общесоматическую патологию, тесно ассоциирована с избыточной массой тела и ожирением, а также с другими компонентами метаболического синдрома, для которых установлено негативное влияние на течение COVID-19.

Рекомендации по терапии пациентов с ГЭРБ на фоне развившейся COVID-19

При назначении лечения по поводу ГЭРБ и симптомов поражения пищевода у пациентов c COVID-19 необходимо провести анализ рисков межлекарственных взаимодействий используемых антисекреторных препаратов, прокинетиков и противорвотных агентов со средствами, применяемыми в терапии COVID-19. Антациды имеют потенциальный риск взаимодействия с азитромицином, хлорохином и гидроксихлорохином; метоклопрамид с хлорохином, гидроксихлорохином, лопинавиром/ ритонавиром. Домперидон не рекомендован в комбинации с лопинавиром/ритонавиром, азитромицином, хлорохином и гидроксихлорохином. Постоянно обновляющийся перечень межлекарственных взаимодействий представлен на электронном ресурсе Ливерпульской группы по лекарственному взаимодействию (The Liverpool Drug Interaction Group) (https://www.covid19-druginteractions.org/).

У пациентов с COVID-19 для контроля симптомов гастроэзофагеального рефлюкса используются ИПП (пантопразол 40 мг/сут., рабепразол 20 мг/сут.), при необходимости - прокинетики (итоприд 150 мг/сут.). Ребамипид (300 мг/сут. - 8 нед.) показан как средство коррекции защитного барьера СO, а также обеспечивает профилактику и лечение НПВП-индуцированных поражений пищевода. В комплексную терапию входят средства коррекции микробно-тканевого комплекса кишечника (пребиотики, метабиотики). Назначение препаратов урсодезоксихолевой кислоты (УДХК) в дозе 10-15 мг/кг массы тела в сут. обусловлено не только коррекцией билиарного рефлюкса, но необходимостью гепатопротекции (на фоне полипрагмазии с использованием гепатотоксичных лекарств).

Хронический гастрит - хроническое прогрессирующее заболевание желудка, морфологически характеризующееся развитием дистрофии, воспале- ния и дисрегенерации СО желудка с исходом в ее атрофию, с частой ассоциацией с инфекцией H. pylori, приводящее к нарушению функций желудка (секреторной, моторно-эвакуаторной, инкреторной и др.), проявляющееся болевым абдоминальным и диспепсическим синдромами, а также экстраорганными нарушениями [17].

Ключевыми компонентами диагностики хронического гастрита являются морфологические изменения СО желудка, характер и выраженность которых напрямую связаны с риском развития онкопатологии, хотя и не всегда ассоциируются с клиническими проявлениями.

Рекомендации по терапии пациентов, не имеющих COVID-19

Особенностью ведения пациентов с хроническим гастритом в условиях пандемии COVID-19 является максимальное использование амбулаторнополиклинического этапа и дистанционных средств коммуникации. Все дополнительные лабораторноинструментальные исследования (в т.ч. диагностика H. pylori) у пациентов с низким риском развития осложнений и онкопатологии могут быть отложены на постпандемический период.

При возникновении осложнений, требующих госпитализации по неотложным показаниям проводится весь необходимый комплекс лечебно-диагностических мероприятий согласно правилам маршрутизации пациентов без COVID-19, нуждающихся в экстренной хирургической помощи [1].

Лечение пациентов с хроническими гастритами направлено на достижении регрессии болевого абдоминального и диспепсического синдромов, нормализацию нарушенных функций желудка, и, что крайне важно, на максимально полноценное восстановление морфо-функциональных характеристик эпителия СО желудка и его регенерации [17, 30].

С учетом негативного влияния антибиотиков на иммунитет и формирования полирезистентной микрофлоры необходим дифференцированный подход к эрадикации H. pylori. При выявлении ассоциированных с $H$. pylori предраковых морфологических изменений, рака желудка, MALT-лимфомы, развитии множественных эрозивных поражений СО желудка и ряда осложнений заболевания необходимо проведение эрадикационной терапии H. pylori с обязательным использованием рекомендованных схем и средств повышения эффективности эрадикации. В клинических рекомендациях Российской гастроэнтерологической ассоциации по диагностике и лечению инфекции $H$. pylori у взрослых среди препаратов, повышающих эффективность эрадикации, представлен ребамипид (УДД 1, УУР В). Мукопротективные свойства ребамипида позволяют рекомендовать его не только для повышения эффективности стандартной эрадикационной терапии инфекции H. pylori, но и для лечения 
постхеликобактерных состояний, особенно при эрозивно-язвенных поражениях СО желудка и двенадцатиперстной кишки (УДД 1, УУР В). Кроме того, среди мер по увеличению эффективности эрадикационной терапии могут быть рассмотрены: двухнедельный курс антибактериальной терапии, двойная доза ИПП, пробиотики [17, 18].

Для купирования симптомов заболевания, ассоциированных с гиперацидностью используются ИПП с минимальным риском межлекарственных взаимодействий (пантопразол 40 мг/сут., рабепразол 20 мг/сут.). Пациентам, которым эрадикация H. pylori отложена, не следует длительно использовать ИПП из-за риска прогрессирования морфологических изменений СО желудка. При наличии моторных нарушений назначаются прокинетики, эффективным препаратом с лучшим профилем безопасности является итоприд (150 мг/сут. до 4 нед.), спазмолитики (мебеверин - 400 мг/сут., гиосцин бутилбромид 30-60 мг/сут.). Билиарный дуоденогастральный рефлюкс требует применения УДХК (10-15 мг/кг массы тела в сут. до 3 мес.) [17].

Назначение ребамипида (300 мг/сут. сроком до 8 нед.) обусловлено его положительным влиянием на все уровни защитного барьера $\mathrm{CO}$ желудка и его проницаемость. Препарат продемонстрировал высокую эффективность у пациентов с хроническим гастритом (в т.ч. рефрактерным к ИПП) в купировании симптомов диспепсии (боль, вздутие, дискомфорт в эпигастрии, отрыжка), нормализации эндоскопической картины, а также восстановлении клеточной структуры СО желудка. Канцеропротективный эффект ребамипида реализуется через восстановление активности сигнального пути sonic hedgehog, что способствует обратимости атрофии клеток желудка, а также через его антиоксидантное, противовоспалительное, антицитокиновое действие. Установлено влияние препарата на обратное развитие кишечной метаплазии и интраэпителиальной неоплазии. Для реализации канцеропревентивного эффекта длительность приема ребамипида увеличивается до 26-52 нед. [3, 30].

В комплексной терапии пациентов с хроническим гастритом используются средства коррекции микробно-тканевого комплекса кишечника (пребиотики, метабиотики).

Хронический гастрит с множественным эрозивным поражением СО желудка, развитием осложнений может негативно влиять на течение COVID-19.

Рекомендации по терапии пациентов с хроническим гастритом на фоне развившегося заболевания COVID-19

При лечении хронического гастрита, а также проявлений поражения желудка на фоне COVID-19 необходимо использовать наиболее безопасные ИПП (пантопразол 40 мг/сут., рабепразол 20 мг/сут.), прокинетики (итоприд - 150 мг/сут.), спазмолитики (мебеверин - 400 мг/сут., гиосцин бутилбромид 30-60 мг/сут.) и противорвотные средства (метоклопрамид по 10 мг внутривенно или внутримышечно 3 раза/сут.) с минимальными рисками межлекарственных взаимодействий со средствами, применяемыми в терапии COVID-19. Домперидон не рекомендован в комбинации с используемыми противовирусными препаратами (https://www. covid19-druginteractions.org/). Обязательным компонентом терапии является гастроэнтеропротектор ребамипид (300 мг/сут.), у которого отсутствуют риски межлекарственных взаимодействий. Препараты УДХК в дозе 10-15 мг/кг массы тела в сут. используются для снижения агрессивности дуоденогастрального рефлюктата и гепатотропной терапии, в комплексной терапии используются средства коррекции микробно-тканевого комплекса кишечника (пребиотики, метабиотики).

Проведение эрадикации $H$. pylori на фоне лечения COVID-19 не целесообразно. После выздоровления пациента от COVID-19 необходимо провести диагностику $H$. pylori и уточнить наличие показаний к его эрадикации.

Лечение НПВП-гастропатии предполагает воздействие на факторы кислотно-пептической агрессии и повышение защитных свойств СО желудка. В этих целях используется ребамипид в комбинации с ИПП. Применение ребамипида (в виде монотерапии или в комбинации с ИПП) также снижает риск и предупреждает возникновение НПВП-гастропатии $[17,19,20,30]$.

Язвенная болезнь (ЯБ) - хроническое, циклически рецидивирующее заболевание желудка и двенадцатиперстной кишки, полиэтиологическое (в большинстве случаев ассоциированное с инфекцией $H$. pylori), морфологическими эквивалентами которого являются язвенный дефект и/или рубцовая деформация в пределах гастродуоденальной $\mathrm{CO}$, манифестирующее характерным болевым абдоминальным, диспепсическим, регургитационным и астено-вегетативным синдромами, осложнениями которого могут быть кровотечение, перфорация, пенетрация, стенозирование и малигнизация [17, 21].

Рекомендации по терапии пациентов, не имеющих COVID-19

Ведение пациентов с обострением (впервые выявленной) ЯБ в условиях пандемии COVID-19 проводится с использованием амбулаторно-поликлинического этапа и телемедицинских консультаций. Из лабораторно-инструментальных исследований проводятся общий анализ крови и анализ кала на скрытую кровь, при первичной диагностике фиброэзофагогастродуоденоскопия (ФГДС), диагностика H. pylori доступным референтным методом $[17,21]$. При возникновении типичных для пациента симптомов обострения ЯБ проведение ФГДС может быть отложено. 
В случае возникновения осложнений, требующих госпитализации по неотложным показаниям (кровотечение, перфорация, пенетрация) проводится весь необходимый комплекс лечебнодиагностических мероприятий согласно правилам маршрутизации пациентов без COVID-19, нуждающихся в экстренной хирургической помощи [1].

Лечение пациентов с ЯБ включает в себя диетическое питание, модификацию образа жизни, отмену препаратов с ульцерогенным действием, лекарственную терапию, направленные на достижение регрессии болевого абдоминального и диспепсического синдромов, нормализацию нарушенных функций желудка и двенадцатиперстной кишки, максимально полноценное заживление язвенного дефекта $[17,21,30]$.

Для заживления язв показано проведение антисекреторной терапии ИПП в течение 4-6 нед. Используются препараты, имеющие самое низкое сродство к системе цитохрома Р450 (пантопразол 40 мг/сут., рабепразол 20 мг/сут.). У пациентов с редкорецидивирующим и неосложненным течением ЯБ эрадикационная терапию выявленной инфекции H. Pylori заболевания целесообразно отложить по эпидемиологическим показаниям.

Для ускорения темпов заживления язв и улучшения качества образующегося рубца показано назначение ребамипида (300 мг/сут. на срок до 8 нед.). Также ребамипид препятствует адгезии H. pylori, снижает риск реколонизации и увеличивает эффективность эрадикационной терапии [17, 21, 30].

В комплексной терапии пациентов с ЯБ применяются средства коррекции микробно-тканевого комплекса кишечника (пребиотики, метабиотики).

Обострение ЯБ, развитие ее осложнений могут оказать негативное влияние на тяжесть течения COVID-19.

Рекомендации по терапии пациентов на фоне развившегося заболевания COVID-19

Лечение ЯБ, а также симптоматических язв желудка и двенадцатиперстной кишки (в т.ч. НПВПассоциированных) на фоне COVID-19 проводится с использованием наиболее безопасных ИПП (пантопразол 40 мг/сут., рабепразол 20 мг/сут.), ребамипида (300 мг/сут.) [17, 19, 20, 21]. В комплексной терапии применяются средства коррекции микробнотканевого комплекса кишечника (пребиотики, метабиотики).

Проведение эрадикации H. pylori на фоне комплексной (в т.ч. антибактериальной) терапии COVID-19 не целесообразно. После выздоровления пациента от COVID-19 проводится диагностика $H$. pylori и уточняются показания к его эрадикации.

\begin{tabular}{|l|} 
Резюме: \\
1. Кислотозависимые заболевания органов пищеварения в фазе \\
обострения и при развитии осложнений могут негативно вли- \\
ять на течение COVID-19. \\
2. Пациентам с кислотозависимыми заболеваниями необходи- \\
мо строго соблюдать противоэпидемические рекомендации \\
с целью снижения риска заражения COVID-19. \\
3. В условиях пандемии COVID-19 ведение пациентов с кислото- \\
зависимыми заболеваниями осуществляется амбулаторно, мак- \\
симально используются дистанционные средства коммуника- \\
ции. ФГдС проводится только при первичной диагностике ЯБ, \\
а также по экстренным показаниям при развитии осложнений. \\
4. Цитопротективный препарат ребамипид восстанавливает \\
защитный барьер СО жКT, эффективно купирует клиниче- \\
ские проявения органической и функциональной диспепсии, \\
способствует быстрому заживлению эрозивно-язвенных пора- \\
жений гастродуоденальной СО и нормализации ее клеточной \\
структуры, оказывает канцеропротективное действие и имеет \\
потенциал для использования в комплексной терапии \\
СОVID-19.
\end{tabular}

\section{3. Заболевания печени}

Пандемия COVID-19 представляет собой огромную проблему для системы здравоохранения всех стран. Пожилые пациенты и пациенты, имеющие хронические заболевания, были определены как группы населения с риском развития тяжелого течения заболевания COVID-19. В настоящий момент обобщены материалы нескольких когортных исследований, которые позволили определить взаимное влияние хронических заболеваний печени и развития COVID-19, а также определены группы риска для гепатологических пациентов. Прежде всего, установлен факт ухудшения прогноза течения COVID-19 у пациентов с повышенной активностью АЛТ, сниженным количеством тромбоцитов и сниженным уровнем альбумина на момент госпитализации, что соответствовало прогрессирующему течению цирроза печени (классификация Чайлда-Пью) [31]. Обобщение результатов лечения, полученных из больницы Оксфордского университета NHS Foundation Trust и Университета Северной Каролины, позволило определить увеличение летальности у пациентов с циррозом печени до 40\% [32]. Наличие декомпенсированного цирроза печени закономерно повышало нежелательный исход заболевания до 43-63\%. Данные также показали, что у многих пациентов с циррозом печени и COVID-19 ухудшался прогноз и по течению хронического диффузного заболевания печени (прогрессирование печеночной энцефалопатии, асцита, повышение риска развития кровотечения).

В настоящее время обсуждается вопрос прямого повреждающего действия вируса SARS-CoV-2 непосредственно на гепатоциты. Установлено, что рецептор АПФ2, используемый вирусом для проникновения в клетку, экспрессируется на холангиоцитах и энтероцитах, что подразумевает опосредованное влияние инфекции на течение хронических заболеваний печени (через билиарный тракт и нару- 
шенный барьер СО кишечника) [33]. В эксперименте установлено, что экспрессия и активность АПФ2 резко повышались в гепатоцитах и в клетках желчных протоков при гипоксии [34].

Необходимо также отметить, что любые системные вирусные инфекции могут протекать с преходящими повышениями активности трансаминаз, которые отражают развитие системной воспалительной реакции, вызванной циркулирующими цитокинами (так называемый “реактивный гепатит”), что, безусловно, будет ухудшать течение хронических заболеваний печени.

В настоящий момент группами риска, наиболее уязвимыми для вируса SARS-CoV-2 с риском негативного прогноза течения COVID-19, необходимо считать пациентов с циррозом печени (особенно декомпенсированным), после трансплантации печени, с аутоиммунными заболеваниями печени, получающими иммунносупресивную терапию, с гепатоцеллюлярной карциномой, с декомпенсированными (прогрессирующее течение) диффузными заболеваниями печени, с неалкогольной жировой болезнью печени (НАЖБП).

Пациенты с НАЖБП или неалкогольным стеатогепатитом (НАСГ), как правило, имеют сопутствующие метаболические заболевания, такие как СД, АГ и ожирение, что относит их к группе повышенного риска развития неблагоприятного течения COVID-19. Таким образом, необходимо отметить, что не только факт наличия НАЖБП относит их к группе риска, а сопряженность (коморбидность) заболевания с рядом факторов, которые имеют уже доказанный негативный прогноз по COVID-19.

Рекомендации по ведению пациентов с хроническими заболеваниями печени для снижения рисков инфицирования и тяжелого течения заболевания

С целью снижения риска заражения COVID-19 всем пациентам с хроническими заболеваниями печени необходимо строго соблюдать общие правила социального дистанцирования. Рекомендуется отложить плановые визиты к специалистам, либо заменить их телефонными контактами/телемедицинскими консультациями, выполнять лабораторные исследования в ближайшей к месту жительства лаборатории.

При необходимости консультирования пациентов с декомпенсированными заболеваниями печени или выполнения им диагностических мероприятий должен быть взвешен риск заражения. Эти соображения требуют адаптации стандартных диагностических процедур для амбулаторной помощи, включая реконструкцию зон ожидания, чтобы иметь достаточное расстояние между пациентами, сокращение времени ожидания и ограничение числа участвующих в процедуре медицинских работников.

Диагностические процедуры

Эндоскопия. ФГДС должна выполняться у пациентов с риском развития кровотечения из вари- козно расширенных вен пищевода. По возможности необходимо проводить неинвазивную оценку риска кровотечения (количество тромбоцитов или Бавено VI).

Эндоскопическая ретроградная холангиография для дилатации или замены стента у пациентов после трансплантации печени или у пациентов с первичным склерозирующим холангитом должна выполняться после тщательного индивидуального анализа риска и пользы, включая риск внутрибольничного инфицирования SARS-CoV-2 в зависимости от локальной нагрузки лечебного учреждения по COVID-19.

УЗИ органов брюшной полости может быть выполнено при наличии доступных ресурсов и оценки индивидуального риска инфицирования в специализированном центре. Пациентам с повышенным риском неблагоприятного течения COVID19 (например, пациентам с повышенным уровнем альфа-фетопротеина, прогрессирующим течением цирроза, хроническим вирусным гепатитом В высокой степени активности, НАСГ/диабетом и т.д.) УЗИ может быть выполнено после оценки реальной угрозы прогрессирования хронического заболевания печени.

Биопсию печени следует отложить у пациентов с НАЖБП или хроническим вирусным гепатитом (для уточнения/постановки диагноза) при умеренно повышенных трансаминазах (например, АЛТ не менее чем в 3 раза выше верхней границы нормы), при уточнении этиологии заболевания печени.

Биопсия должна выполняться у пациентов со значительным повышением трансаминаз (например, АЛТ >5xN) неизвестной этиологии (в случаях предполагаемых аутоиммунных заболеваний печени, лечение без гистологического диагноза может проводиться, исходя из индивидуальных соображений риска и выгоды, а также на основании лабораторной диагностики), с подозрением на злокачественные новообразования.

\section{Ведение пациентов}

У пациентов с аутоиммунными заболеваниями печени рекомендуется не снижать иммуносупрессивную терапию. Уменьшение следует рассматривать только в особых случаях (например, вызванная лекарствами лимфопения или бактериальная/грибковая суперинфекция) после консультации специалиста. Также есть мнение, что иммуносупрессия может рассматриваться как дополнительный фактор, способный обеспечить определенную защиту от иммунопатологических реакций, которые способствуют повреждению легких в случаях с более тяжелыми проявлениями COVID-19 [35].

У пациентов с компенсированным циррозом следует рассмотреть возможность неинвазивной оценки риска развития осложнений - кровотечения из варикозно-расширенных вен пищевода (количество тромбоцитов или критерии Baveno VI). 
Лист ожидания трансплантации печени должен быть ограничен пациентами с плохим краткосрочным прогнозом в т.ч. с острой/острой на фоне хронической печеночной недостаточностью, высокими показателями по шкале прогноза MELD ( $\geqslant 25$ баллов). Рекомендуется сокращение программы обследования пациента перед проведением трансплантации печени в стационаре до строго необходимой, а также сократить количество консультаций в других отделениях/клиниках (офтальмологических, дерматологических, стоматологических, неврологических) или провести их в амбулаторных условиях.

Следует тщательно выполнять рекомендации по профилактике спонтанного бактериального перитонита и печеночной энцефалопатии.

Регулярное тестирование на SARS-CoV-2 следует проводить перед трансплантацией у донора и реципиента. Согласие на диагностические и терапевтические процедуры, связанные с трансплантацией печени, должно включать потенциальный риск внутрибольничного инфицирования SARSCoV-2.

Рекомендации по ведению пациентов с хроническими заболеваниями печени и COVID-19

Лечение пациентов с хроническим заболеванием печени и желчевыводящих путей требует от врача, прежде всего, определить симптомы, не укладывающиеся в клиническую картину COVID-19, и найти им объяснение с позиций, имеющейся у пациента патологии (хронических заболеваний печени и/или желчевыводящих путей).

На сегодняшний день выделяют следующие механизмы повреждения печени при COVID-19 [36]:

1. Иммунно-опосредованное повреждение вследствие тяжелой воспалительной реакции при COVID-19. Биомаркеры воспаления, включая C-реактивный белок, сывороточный ферритин, лактатдегидрогеназа, интерлейкины: ИЛ-6, ИЛ-2 были достоверно повышены у тяжелых пациентов c COVID-19.

2. Прямая цитотоксичность, обусловленная активной репликацией вируса в клетках печени и холангиоцитов. SARS-CoV-2 связывается с мишенью клетки через АПФ2. АПФ2 обильно экспрессируется в печени и в билиарных эпителиальных клетках (холангиоцитах).

3. Реактивация (обострение) ранее существовавшего заболевания печени. Пациенты с ранее существовавшим хроническим заболеванием печени могут быть более восприимчивы к повреждению печени от COVID-19 вследствие увеличения экспрессии АПФ2 рецепторов при диффузных поражениях печени.

Также необходимо учитывать повышенную нагрузку на гепатобилиарную систему пациентов в условиях течения COVID-19: интоксикационный синдром, НПВП, антибактериальные и противови- русные средства. Это обстоятельство требует мониторинга состояния гепатобилиарной системы в течение всего периода лечения COVID-19 пациентов с хроническим заболеванием печени и желчевыводящих путей. Мониторинг включает оценку основных биохимических гепатологических синдромов (синдром цитолиза, холестаза, печеночноклеточной недостаточности и иммуновоспалительного). При появлении клинической симптоматики поражения гепатобилиарной системы необходимо провести УЗИ органов брюшной полости, поскольку полученные данные могут повлиять на тактику ведения пациентов.

Пациенты с хроническими заболеваниями печени и/или желчевыводящих путей, инфицированные SARS-CoV-2, могут поступать в инфекционные отделения и больницы для лечения COVID-19. Поскольку в таких учреждениях может отсутствовать возможность оказания специализированной гепатологической помощи, специализированным центрам рекомендуется предоставлять возможность дистанционных гепатологических консультаций (согласно приведенным выше рекомендациям).

При лечении пациентов с хроническими заболеваниями печени и/или желчевыводящих путей следует также учитывать возможные побочные эффекты. Это особенно важно при оценке лекарственных взаимодействий у пациентов, получающих иммуносупрессивную терапию, а также с нарушенной функцией печени (например, с циррозом печени класса В/С по классификации Чайлда-Пью). У этих пациентов значительно повышается риск лекарственной токсичности. Также важно подчеркнуть, что все изучаемые в настоящее время препараты не получили однозначного одобрения в качестве этиотропного лечения COVID-19, поэтому, в случае развития токсического поражения печени у данной категории пациентов, необходимо соблюдать протокол ведения пациентов с лекарственным гепатитом.

Следует избегать передозировки ацетаминофена (доза 2-3 г/сут. считается безопасной у пациентов с циррозом печени без активного употребления алкоголя), а также минимизировать прием НПВП у пациентов с циррозом печени и портальной гипертензией. В случае необходимости использования НПВП, включать в комплексную терапию ребамипид в стандартной дозировке (300 мг/сут.) с целью предупреждения риска развития кровотечения, а также нормализации функции печени.

В настоящий момент в группу риска наиболее уязвимых гепатологических больных для COVID19 , с риском негативного прогноза течения заболевания, необходимо относить:

1. Пациентов с циррозом печени (особенно декомпенсированным).

2. Пациентов после трансплантации печени. 
3. Пациентов с аутоиммунными заболеваниями печени, получающих иммунносупресивную терапию.

4. Пациентов с гепатоцеллюлярной карциномой.

5. Пациентов с декомпенсированными (прогрессирующее течение) диффузными заболеваниями печени.

6. Пациентов с НАЖБП.

Пациенты с НАЖБП или НАСГ, как правило, имеют сопутствующие метаболические заболевания, такие как СД, АГ и ожирение, а также вынуждены принимать большое количество потенциально гепатотоксичных препаратов, что относит их к группе повышенного риска заражения SARS$\mathrm{CoV}-2$, а также - тяжелого протекания этой инфекции. Это делает НАЖБП не менее опасной в плане тяжелого течения COVID-19, чем вирусные гепатиты, аутоиммунный гепатит и фиброз/цирроз печени. По данным Gao F, et al. (2020), у недиабетических пациентов с COVID-19 наличие НАЖБП ассоциировалось с 4-кратным повышением риска развития тяжелой COVID-19. При этом, вероятность осложнений повышалась с увеличением числа метаболических факторов риска. Ассоциация с тяжестью COVID-19 сохранялась и после корректировки с учетом возраста, пола и сопутствующих патологических состояний [37].

Поэтому, пациенты с НАЖБП в период пандемии COVID-19 нуждаются в особом внимании врачей для снижения уровня повреждения печени (степени стеатоза и фиброза) и нормализации печеночных трансаминаз. Чем меньше степень структурных изменений печени, тем меньше рецепторов АПФ2 в ней, ниже риск ее инфицирования и повреждения вирусом.

В условиях пандемии COVID-19 для пациентов c хроническими заболеваниями гепатобилиарной системы, печеночными проявлениями COVID-19, гепатотоксичными эффектами проводимой терапии, а также с целью предотвращения тяжелых осложнений COVID-19 со стороны печени патогенетически обоснованным средством является УДХК. Препарат оказывает гепатопротективный и цитопротективный эффект как в отношении гепатоцитов, так и холангиоцитов (клеток-мишеней для коронавируса), чего не установлено у других гепатотропных средств, а также обладает антифибротическим, иммуномодулирующим и регулирующим апоптоз действием. УДХК обладает способностью тормозить развитие фиброза и оказывать выраженное системное иммуномодулирующее и противовоспалительное воздействие не только в печени, а и в других органах и системах, что может быть актуальным для профилактики фиброза легких, типичного осложнения COVID-19. В эксперименте УДХК значительно уменьшала липополисахарид-индуцированный отек легких и воспалительные изменения в легких за счет стимуляции выведения жидкости из альвеол, что может быть актуально в комплексной терапии отека легких - смертельного осложнения COVID-19. Вследствие своих плейотропных эффектов, УДХК является препаратом выбора для пациентов с НАЖБП, коморбидная отягощенность которых составляет потенциальную группу риска тяжелого течения COVID-19. По данным международного исследования "УСПЕХ" установлено, что применение 15 мг/кг массы тела УДХК (Урсосан ${ }^{\circledR}$ ) в сутки на протяжении 24-х нед. при НАЖБП приводит к уменьшению активности воспалительных процессов в печени, ее стеатоза, улучшает показатели липидного обмена и обладает антиатерогенными свойствами. Оптимизация обмена веществ у пациентов с COVID-19 может положительно влиять на прогноз течения инфекции [3, 38].

\section{Диагностические процедуры}

Эндоскопические процедуры связаны с повышенным риском распространения SARS-CoV-2. Показания к эндоскопическим процедурам у пациентов с COVID-19 должны ограничиваться чрезвычайными ситуациями, такими как желудочнокишечное кровотечение, бактериальный холангит или другими угрожающими жизни условиями.

УЗИ должно быть отложено до выздоровления. Исключение могут составлять пациенты с выраженным обострением хронического заболевания с целью уточнения лечебной стратегии (хронический калькулезный холецистит, бактериальный холангит, обострение билиарнозависимого панкреатита).

Биопсия печени должна быть отложена у большинства пациентов, т.к. лечение COVID-19 значительно важнее, чем диагностика сопутствующего заболевания печени; связанное с COVID-19 системное воспаление затрудняет оценку гистологических характеристик, специфичных для этиологии заболевания печени; биопсия печени может создавать риск передачи вируса (хотя до настоящего времени вирус не был обнаружен в ткани печени, экспрессия его рецептора на холангиоцитах указывает на такую возможность). В особых случаях стратегия вырабатывается индивидуально, на основании коллегиального решения.

\footnotetext{
Резюме:

1. Хронические заболевания печени в стадии декомпенсации ухудшают прогноз течения COVID-19.

2. Пациентам с хроническими заболеваниями печени необходимо строго соблюдать все противоэпидемические правила с целью снижения риска заражения COVID-19.

3. COVID-19 может стать причиной декомпенсации у пациентов с хроническими диффузными заболеваниями печени.

4. Гастроэнтерологические проявления COVID-19 у данной категории пациентов могут быть клиническим проявлением обострения имеющихся хронических заболеваний печени.

5. Хронические заболевания печени являются крайне неблагоприятным фоном для развития лекарственного поражения печени, что требуют особого мониторинга для данной категории пациентов.
} 


\section{4. Воспалительные заболевания кишечника}

У пациентов с хроническими иммуновоспалительными заболеваниями, к которым принадлежат болезнь Крона (БК) и язвенный колит (ЯК), имеется потенциальный повышенный риск инфицирования SARS-CoV-2. Это связано, прежде всего, с часто получаемой иммуносупрессивной терапией для контроля активности ВЗК. Кроме того, необходимость нахождения в медицинских учреждениях в связи с проведением регулярных лечебных или диагностических процедур может увеличить частоту контакта с носителями SARS-CoV-2. Несмотря на этот потенциальный риск, имеющиеся опубликованные данные пока не свидетельствуют о повышенной заболеваемости COVID-19 у пациентов B3K [39].

В настоящее время создан международный реестр учета пациентов с ВЗК и подтвержденным инфицированием SARS-CoV-2 (SECURE-IBD Database). Из 1302 зарегистрированных на момент написания данных рекомендаций пациентов (36 больных из РФ) госпитализация потребовалась 396 (30\%) в связи с тяжелым течением B3K или COVID19 (или обоими состояниями). Смертность составила $3 \%$ (45 больных) с некоторым преобладанием летальных исходов у мужчин $(5 \%$, в сравнении с женщинами $-2 \%$ ), и несколько выше смертность наблюдалась при ЯК (5\%) по сравнению с БК (2\%) [40].

\section{Определение, диагностика}

ЯК - хроническое заболевание толстой кишки, характеризующееся иммунным воспалением ее $\mathrm{CO}[41]$.

БК - хроническое, рецидивирующее заболевание ЖКТ неясной этиологии, характеризующееся трансмуральным, сегментарным, гранулематозным воспалением с развитием местных и системных осложнений [42].

У пациентов с COVID-19 нередко развиваются симптомы поражения ЖКТ, что может симулировать обострение и/или прогрессирование В3К [40].

В таблице 2 представлены обобщенные данные по дифференциальной диагностике гастроэнтерологических симптомов COVID-19 и симптомов обострения В3К, основанные на текущих национальных рекомендациях $[41,42]$ и опубликованных данных [43].

Применение данного дифференциального подхода позволит избежать дополнительного посещения медицинских учреждений для проведения уточняющих эндоскопических процедур и лучевых методов исследований. В этих условиях фекальный кальпротектин может быть использован как неинвазивный маркер активности воспаления при В3К. В период пандемии COVID-19 эндоскопические и лучевые методы исследований должны быть ограничены теми, которые срочно необходимы или будут непосредственно влиять на лечение ВЗК (КТ или МРТ для диагностики осложнений, например, абсцесса или непроходимости) [44].

Рекомендации по терапии пациентов с ВЗК, не имеющих COVID-19, направленные на снижение рисков инфицирования SARS-CoV-2 и тяжелого течения заболевания в случае инфицирования

Необходимо избегать прерывания поддерживающей ремиссию ВЗК терапии, т.к. это может привести к обострению ВЗК с риском назначения системных кортикостероидов, что является доказанным

Дифференциальный диагноз гастроэнтерологических симптомов при COVID-19 и обострении B3К

\begin{tabular}{|c|c|c|}
\hline Симптомы & COVID-19 & Обострение ВЗК \\
\hline \multicolumn{3}{|c|}{ Гастроэнтерологические симптомы } \\
\hline Потеря аппетита & $39,9-78,6 \%$ & Редко, при выраженной интоксикации \\
\hline Диарея & $2-49,5 \%$ & Характерно \\
\hline Тошнота, рвота & До $1 / 3$ случаев & Редко, при выраженной интоксикации \\
\hline Боль в животе & Нечасто $-2,2-6,0 \%$ & Характерно \\
\hline Кровотечение & $\begin{array}{l}\text { Как из верхних, так из нижних отделов ЖКТ } \\
4-13,7 \%\end{array}$ & $\begin{array}{l}\text { Ректальное кровотечение характерно для ЯК. } \\
\text { Для БК при поражении толстой кишки }\end{array}$ \\
\hline $\begin{array}{l}\text { Императивные позывы на дефекацию, } \\
\text { тенезмы }\end{array}$ & Не описаны & Характерно для ЯК \\
\hline Потеря вкуса & $5,6-88 \%$ & Не характерно \\
\hline \multicolumn{3}{|c|}{ Лабораторные исследования } \\
\hline Клинический анализ крови & $\begin{array}{l}\text { Лейкопения, лимфопения, реже - } \\
\text { тромбоцитопения } \\
\text { При ОРДС - характерны лейкоцитоз, } \\
\text { нейтрофилез и лимфопения }\end{array}$ & $\begin{array}{l}\text { Лейкоцитоз (на фоне хронического воспаления, } \\
\text { при наличии абсцесса или на фоне стероидной } \\
\text { терапии). } \\
\text { При высокой активности - тромбоцитоз }\end{array}$ \\
\hline СРБ крови & 个 коррелирует с тяжестью течения & 个 коррелирует с тяжестью течения \\
\hline Лактатдегидрогеназа крови & $\uparrow \uparrow$ & Норма \\
\hline Ферритин крови & $\uparrow \uparrow$ & Норма или снижен \\
\hline Фекальный кальпротектин кала & Не описано & $\begin{array}{l}\uparrow \text { коррелирует с распространенностью } \\
\text { патологического процесса в кишечнике }\end{array}$ \\
\hline
\end{tabular}


Таблица 3

Рекомендации по ограничительным мерам в условиях пандемии в зависимости от факторов риска тяжелого течения COVID-19 [45]

\begin{tabular}{|c|c|c|}
\hline Очень высокий риск & Средний риск & Низкий риск \\
\hline Рекомендована обязательная самоизоляция & $\begin{array}{l}\text { Рекомендовано строгое социальное } \\
\text { дистанцирование }\end{array}$ & Рекомендовано социальное дистанцирование \\
\hline 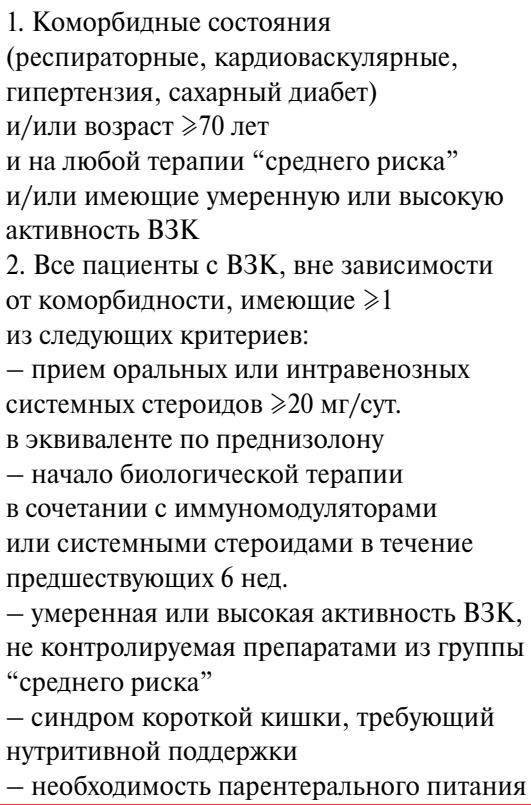 & $\begin{array}{l}\text { Пациенты, получающие следующие лекар- } \\
\text { ственные препараты: } \\
\text { - Монотерапия анти-ФНО препаратами } \\
\text { (инфликсимаб, адалимумаб, голимумаб, } \\
\text { цертолизумаб) } \\
\text { - Биологические препараты + } \\
\text { иммуносупрессоры у стабильных пациентов } \\
\text { (кроме случаев начала терапии в течение } \\
6 \text { нед.) } \\
\text { - Устекинумаб } \\
\text { - Ведолизумаб } \\
\text { - Тиопурины (азатиоприн, меркаптопурин) } \\
\text { - Метотрексат } \\
\text { - Ингибиторы кальциневрина* } \\
\text { - Ингибиторы ЈАК-киназы (тофацитиниб) } \\
\text { - Иммуносупрессивная терапия в рамках } \\
\text { клинических исследований } \\
\text { - Микофенолат мофетил. Талидомид* } \\
\text { - Системные кортикостероиды <20 мг/сут. } \\
\text { в пересчете на преднизолон }\end{array}$ & $\begin{array}{l}\text { Пациенты, получающие следующие лекар- } \\
\text { ственные препараты: } \\
\text { - 5-АСК } \\
\text { - Терапия ректальными формами } \\
\text { - Пероральные формы топических } \\
\text { стероидов - будесонид или бекламетазон* } \\
\text { - Препараты для лечения хологенной } \\
\text { диареи (холестирамин*, колестипол*) } \\
\text { - Противодиарейные средства (например, } \\
\text { лоперамид) } \\
\text { - Антибактериальные препараты } \\
\text { для лечения перианальных поражений } \\
\text { или синдрома избыточного бактериального } \\
\text { роста }\end{array}$ \\
\hline
\end{tabular}

Примечание: * - препараты не указаны в Российских национальных рекомендациях по ведению пациентов с ВЗК; ВЗК - воспалительные заболевания кишечника, 5-АСК - 5-аминосалициловая кислота.

фактором риска возникновения инфекционных осложнений [45].

В связи с тем, что пациенты с ВЗК должны продолжать поддерживающую терапию Британским обществом гастроэнтерологов по изучению ВЗК была предложена стратификация рисков для пациентов с ВЗК, в т.ч. исходя из проводимой терапии, [45]. В соответствии с той стратификацией были разработаны ограничительные меры для таких пациентов (таблица 3).

В опубликованных данных высказывается предположение, что повышенная проницаемость кишечника при обострении ВЗК, так же, как и высокая экспрессия рецепторов АПФ2 для проникновения SARS-CoV-2 может быть предрасполагающим фактором для заражения пациентов через ЖКТ [36]. Сохранение клинической ремиссии ВЗК на фоне стабильной терапии существенно уменьшает кишечную проницаемость [46]. Таким образом, использование препаратов для поддержания ремиссии ВЗК и уменьшения проницаемости кишечного барьера (ребамипид) является важным аспектом профилактики потенциального риска инфицирования SARSCoV-2 через гастроэнтерологический тракт.

В результате совещания экспертов Международной организации по изучению воспалительных заболеваний кишечника (IOIBD) (89 ученых-вра- чей из 26 стран) был опубликован список групп препаратов, используемых при ВЗК, с точки зрения влияния на риск инфицирования SARS-CoV-2 [47]:

1. Препараты для лечения ВЗК, прием которых не увеличивает риск инфицирования SARS-CoV-2: месалазин, сульфасалазин, будесонид, ведолизумаб, устекинумаб.

2. Препараты для лечения ВЗК, прием которых, возможно, увеличивает риск инфицирования SARS-CoV-2: оральный преднизолон $\geqslant 20$ мг/сут. (или другие системные кортикостероиды в эквивалентной дозе).

3. Препараты для лечения ВЗК с неизвестной позицией по риску увеличения инфицирования SARS-CoV-2: ингибиторы ФНО- $\alpha$, тиопурины, метотрексат, тофацитиниб.

Рекомендации по терапии пациентов с В3К на фоне заболевания COVID-19

В опубликованных когортных исследованиях указывается, что факторами неблагоприятного течения COVID-19 при ВЗК является активность ЯК или БК, возраст и коморбидность пациентов [48]. Авторы делают вывод, что предупреждение обострения ВЗК поможет избежать фатального течения COVID-19.

При выявлении SARS-CoV-2, но без проявления COVID-19, пациенты безопасно могут продол- 
жить оральный и ректальный прием препаратов 5-АСК (месалазин, сульфасалазин). В случае приема стероидов, пациентов следует перевести на более низкие дозы преднизолона (<20 мг/сут.) или на будесонид, когда это возможно. Доступные скими препаратами (ингибиторы ФНО- $\alpha$, ведолизумаб или устекинумаб) должны быть отложены на 2 нед. После 2-х недельного перерыва, если по-прежнему нет проявлений COVID-19, лечение генноинженерными биологическими препаратами можно возобновить. Если при выявлении SARS-CoV-2 пациент находился на терапии иммуносупрессорами (тиопурины, метотрексат) или на приеме тофацитиниба, прием данных препаратов должен быть временно прекращен [45, 49].

У пациентов с ВЗК, имеющих клинические следует определить тяжесть COVID-19.

При легком течении COVID-19 госпитализация не требуется. Необходимо снизить дозу системных кортикостероидов (до 20 мг/сут. и ниже) или перевести на будесонид (за исключением случаев использования лопинавир/ритонавир [1]). Лечение препаратами 5-АСК следует продолжить. Тиопурины, метотрексат и тофацитиниб следует прекратить. Введение биологических препаратов следует отложить на 2 нед. (возобновить при условии отрицательного теста на SARS-CoV-2) [45, 49].

При среднетяжелом и тяжелом течении COVID19 пациенты подлежат госпитализации по показаниям с фокусом на проведение лечения SARSCoV-2. При выборе терапии для COVID-19 следует учитывать следующие факторы: ограничение введения внутривенных стероидов тремя днями, по возможности быстрое снижение орального приема методы лечения генно-инженерными биологичепроявления COVID-19, для выбора тактики лечения

преднизолона или переключения на будесонид, учитывая взаимодействие с лопинавир/ритонавиром. Можно продолжить прием препаратов 5-АСК, возможно использовать ректальную пену будесонида. Тиопурины, метотрексат и тофацитиниб следует прекратить на весь период острых проявлений COVID-19, хотя в настоящее время проводятся исследования тофацитиниба для лечения COVID19. Лечение биологическими препаратами можно отложить как минимум на 2 нед. до разрешения симптомов COVID-19 или выработки анти-SARSCoV-2-антител [45, 49, 50].

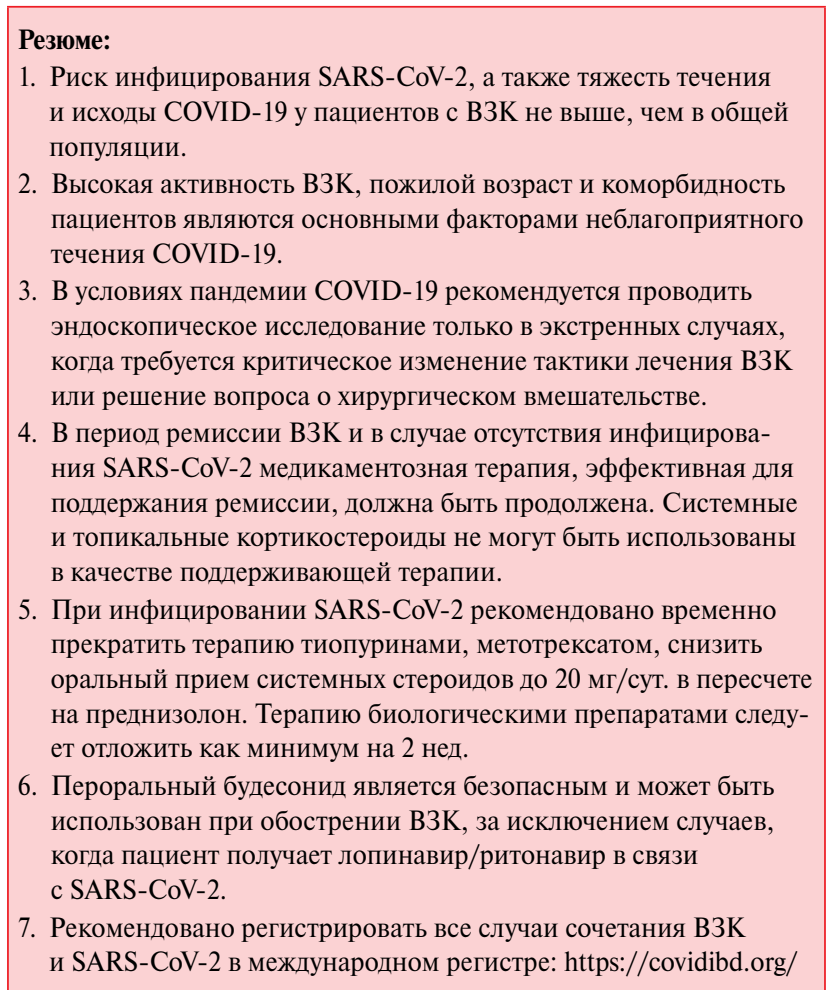

\section{5. Синдром раздраженного кишечника}

Современная концепция патогенеза СРК основывается на формировании висцеральной гиперчувствительности и нарушения моторики кишечника в условиях генетической предрасположенности и влияния психосоциальных факторов [51].

Пандемия COVID-19, ее информативное сопровождение, безусловно, оказывает существенное влияние на психологический статус населения. В Китае, в период пика эпидемии, было проведено исследование состояния психоэмоциональной сферы 1210 жителей 194 городов посредством заполнения он-лайн опросников. Более половины (53,8\%) респондентов отметили влияние COVID-19 на их психологическое состояние как средней и тяжелой степени выраженности, у 16,5\% были выявлены депрессивные симптомы, у 28,8\% - тре- вожные расстройства, а $8,1 \%$ опрашиваемых сообщили об умеренном и сильном уровне стресса [52]. Установлено, что SARS-CoV-2 в кишечнике может влиять на абсорбцию триптофана через АПФ2, приводя к снижению содержания антимикробного пептида и, следовательно, изменяя кишечную микробиоту, вызывая воспаление кишечника [5].

Таким образом, в настоящее время имеется основание для ожидания роста впервые выявленных случаев СРК, а также увеличению выраженности гастроэнтерологических симптомов у пациентов с уже установленными функциональными заболеваниями. Эту ситуацию необходимо дифференцировать со случаями диарейного синдрома у пациентов с подтвержденным инфицированием SARS-CoV-2, т.к. известна тропность SARS-CoV-2 к эпителиальным клеткам терминального отдела подвздошной кишки и толстой кишки [53]. 


\section{Определение, классификация}

СРК - функциональное расстройство кишечника, проявляющееся рецидивирующей болью в животе, возникающей по меньшей мере 1 раз в нед., которая характеризуется следующими признаками (двумя или более): связана с дефекацией, сочетается с изменением ее частоты и/или формы кала. Эти симптомы должны отмечаться у больного в последние 3 мес. при общей продолжительности наблюдения не менее 6 мес. [51].

В подавляющем числе случаев в период эпидемии COVID-19 диагностику CPK можно отложить. Исключение составляет диарейный сидром у пациентов с подтвержденным инфицированием SARS$\mathrm{CoV}-2$. У таких пациентов необходимо проведение дифференциальной диагностики между поражением ЖKT, вызванным SARSCoV-2 и течением (ухудшением) СРК [3].

Рекомендации по терапии пациентов с СРК, не имеющих COVID-19, направленной на снижение рисков инфицирования SARS-CoV-2 и тяжелого течения заболевания, в случае инфицирования

Пациентам с СРК следует рекомендовать соблюдение режима социального дистанцирования, a, когда возможно, самоизоляции.

В настоящее время не опубликовано результатов исследований, подтверждающих протективное действие каких-либо препаратов, используемых при СРК, на возможность или степень инфицирования SARS-CoV-2.

Исходя из парадигмы изменения кишечной проницаемости при многих заболеваниях ЖКТ, включая функциональные, рекомендовано использование средств, регулирующих синтез простагландинов Е2 и I2 в СО кишечника и повышающих образование макромолекулярного гликопротеинового комплекса. Для решения этой задачи в арсенале практикующего врача в настоящее время имеется только одно средство - ребамипид [54].

Важным разделом лечения пациентов с СРК является создание терапевтического союза между врачом и пациентом, соглашение в отношении лечебной стратегии. Данный аспект лечения СРК затруднен в условиях ограниченной возможности прямого (очного) контакта между врачом и пациентом и должен быть реализован с использованием возможностей телемедицины.

Рекомендации по терапии пациентов с СРК на фоне заболевания COVID-19

Для лечения COVID-19 используется по показаниям фавипиравир и по решению врачебной комиссии допускается применять следующие препараты: гидроксихлорохин, хлорохин, мефлохин, азитромицин, лопинавир и ритонавир, интерфероны, умифеновир, а также препараты упреждающей противовоспалительной терапии [1].

В настоящее время не зарегистрировано неблагоприятных взаимодействий между препаратами, используемыми для купирования симптомов СРК и основными лекарственными средствами, рекомендуемыми для лечения COVID-19. Однако препараты для лечения COVID-19 имеют побочные эффекты со стороны ЖКТ, которые необходимо дифференцировать с симптомами СРК [55] (таблица 4).

Лечение побочных гастроэнтерологических эффектов, так же, как и проявлений СРК основано на симптоматическом подходе [51, 55].

При необходимости продолжения терапии COVID-19 и выраженной диарее необходима адекватная регидратация и поддержание электролитного баланса. Не противопоказано применение препаратов для контроля диареи (лоперамид) [55]. Однако, учитывая влияние ритонавира на уровень лоперамида в крови, при совместном использовании этих препаратов не рекомендовано превышать максимальную суточную дозу лоперамида (16 мг). В целях купирования абдоминальной боли пациентам с СРК рекомендованы спазмолитические препараты (гиосцина бутилбромид, пинаверия бромид, мебеверин) [51]. В случае некупирующейся боли в животе на фоне первичной симптоматической терапии, необходимо рассмотреть возможность дебюта других синдромосходных состояний и про-

Препараты для лечения COVID-19 и их побочные эффекты со стороны ЖКТ

Таблица 4

\begin{tabular}{lll}
\hline Препарат & Побочные эффекты со стороны ЖКТ & $\begin{array}{l}\text { Побочные эффекты, которые необхдимо } \\
\text { дифференцировать с симптомами СРК }\end{array}$ \\
\hline Гидроксихлорохин хлорохин, мефлохин & Тошнота, рвота, потеря веса, боль в животе & Боль в животе \\
\hline Азитромицин & Диарея, тошнота, рвота, боль в животе & Диарея, боль в животе \\
\hline Лопинавир и ритонавир & Увеличение печеночных ферментов & Нет \\
\hline Рекомбинантный интерферон бета-1b & $\begin{array}{l}\text { Увеличение печеночных ферментов, } \\
\text { тошнота, рвота, диарея, запор, } \\
\text { боль в животе }\end{array}$ & Диарея, запор, боль в животе \\
\hline Тоцилизумаб & Увеличение печеночных ферментов, & вивоте \\
& перфорация кишки, панкреатит, & боль в животе
\end{tabular}

Примечание: ЖКТ - желудочно-кишечный тракт, СРК - синдром раздраженного кишечника. 
вести углубленный диагностический поиск для исключения органической патологии кишечника.

Резюме:
1. Нет данных о повышенной заболеваемости COVID-19 у паци-
ентов с СРК.
2. Информационное освещение проблемы COVID-19 часто
вызывает стрессовое влияние на психологический статус насе-
ления, что может быть причиной роста впервые выявленных
случаев CPK, а также усиления выраженности симптомов
у пациентов с уже установленным диагнозом.
3. В подавляющем числе случаев первичную диагностику СРК
можно отложить. Исключение составляют: упорный болевой
абдоминальный синдром, не купирующийся симптоматиче-
ской терапией, появление “симптомов тревоги” и диарейный
сидром у пациентов с подтвержденным инфицированием
SARS-СоV-2.
4. Лечение СРK в условиях пандемии СОVID-19 не отличается
от принятых в Российских национальных рекомендациях
принципов. Неблагоприятного взаимодействия препаратов
для купирования симптомов СРК и лекарственных средств для
лечения COVID-19 при приеме рекомендуемых инструкцией
доз не зарегистрировано.
5. В случае развития побочных эффектов со стороны ЖКT при
лечении СOVID-19 (абдоминальная боль, диарея, запор) прием
лекарственных средств в большинстве случаев может быть про-
должен на фоне применения симптоматической терапии.

\section{6. Хронический панкреатит}

Актуальность обсуждения особенностей ведения больных COVID-19 с ХП обусловлена вероятностью повторных “волн” COVID-19, высокой частотой ХП, этиологическими факторами (алкоголь, табакокурение, инфекции - в т.ч. вирусные), развитием СД, трофологической недостаточности, которые относятся к факторам риска тяжелого течения COVID19.

Анализ клинического течения коронавирусных инфекций - SARS-CoV (2002 - июль 2003), MERSCoV и нынешняя пандемия COVID-19, не позволяет сделать убедительных и достоверных выводов о взаимовлияния COVID-19 и ХП [1, 4].

В настоящее время появляется все больше работ, свидетельствующих о поражении поджелудочной железы у пациентов с COVID-19. Изменения включают преходящий стеатоз, отек поджелудочной железы без значительного некроза поджелудочной железы с отчетливым воспалением двенадцатиперстной кишки, проявления истинной экзокринной недостаточности поджелудочной железы, требующие лечения [56, 57].

Современные представления по диагностике и лечению ХП отражены в международных и национальных, в т.ч. и российских (РГА, НОГР, “Профессиональное медицинское сообщество "Панкреатологический клуб”), рекомендациях [58-62], основанных на принципах доказательной медицины.

ХП - группа хронических заболеваний поджелудочной железы различной этиологии, воспалительной природы, характеризующихся болью в верхних отделах живота, развитием необратимых структурных изменений паренхимы и протоков, замещением их соединительной (фиброзной) тканью и формированием вследствие этого экзокринной и эндокринной панкреатической недостаточности [58].

Распространенность в России - 27,4-50 случаев на 100 тыс. населения, наблюдается тенденция к увеличению заболеваемости острым и ХП, обычно ХП развивается в среднем возрасте (35-50 лет) [58]. Летальность после первичного установления диагноза ХП составляет до $20 \%$ в течение первых 10 лет и $>50 \%$ - через 20 лет.

Для пациентов с XП без COVID-19 на наш взгляд большое значение имеют профилактические меры, включающие: а) диспансерное наблюдение (своевременные - диагностика, профилактика и лечение обострений, компенсация экзо-эндокринной недостаточности), б) профилактическое лечение (индивидуально).

Персонифицированный подход по указанным направлениям определяется этиологией (алкогольный, билиарнозависимый, аутоиммунный, лекарственный, инфекционный и др.), степенью тяжести, клиническими проявлениями, характером течения (частота, тяжесть обострений), длительностью и фазой заболевания (ремиссия/обострение), наличием/отсутствием осложнений, эффективностью проводимого лечения.

Для диагностики: 1) внешнесекреторной функции ПЖ оценивают клинические проявления (стеаторея, метеоризм, снижение массы тела), уровень панкреатической эластазы- 1; 2) эндокринной (внутрисекреторной) недостаточности: уровень глюкозы крови натощак, глюкозотолерантный тест, определение концентрации гликированного гемоглобина $\mathrm{A}_{\mathrm{lc}}\left(\mathrm{HbA}_{\mathrm{lc}}\right)$; 3) трофологического статуса определяют: индекс массы тела, гемоглобин, общий белок, альбумин, абсолютное количество лимфоцитов, (при наличии возможности дополнительно ретинол-связывающий белок, витамин $\mathrm{B}_{12}$, фолиевую кислоту, трансферрин, магний, цинк) [58, 62, 63]. При выявлении внешнесекреторной недостаточности осуществляется нутритивная поддержка: исключение алкоголя и табакокурения, достаточное содержание белка в рационе, нормализация содержания в пище жиров (преимущественно среднецепочечные триглицериды, моно- и полиненасыщенные жирные кислоты), адекватная полиферментная терапия (см. ниже). При развитии трофологической недостаточности: назначается парентеральное, энтеральное, либо комбинированное питание, витаминно-минеральные комплексы, содержащие высокие дозы витаминов и микроэлементов с антиоксидантными свойствами [59, 63].

В соответствии с временными рекомендациями Минздрава рекомендовано проведение профилак- 
тического лечения лицам с высоким риском заболевания COVID-19. Предлагается к обсуждению профилактическое лечение больных с ХП при наличии признаков суб-/декомпенсации экзо- и/или эндокринной функции, особенно в сочетании с другими состояниями (возраст старше 60 лет, АГ, ССЗ), которые относятся к факторам риска неблагоприятного течения COVID-19 [1, 4]. Для определения конкретного варианта профилактического лечения (рекомбинантный интерферон альфа, гидроксихлорохин или мефлохин) важен анализ ранее перенесенных вирусных заболеваний (частота, тяжесть течения, осложненное течение, эффективность проводившегося лечения), в сложных клинических ситуациях возможно обсуждение конкретного больного с иммунологом. Требует наблюдения и анализа эффект профилактического лечения в зависимости от этиологии ХП (билиарнозависимый, алкогольный, инфекционный, аутоиммунный, лекарственный и др.).

С учётом высокой частоты сочетания (коморбидности) ХП с другими заболеваниями ЖКТ, среди которых наиболее часто встречаются эрозивный эзофагит и гастродуоденальные язвы [63], а также принимая во внимание то, что поражение CO ЖКТ может способствовать развитию COVID19, необходимо уделять особое внимание профилактике гастроинтестинальных осложнений ХП. С этой целью возможно назначение препарата ребамипид, который доказал свою эффективность как в профилактике, так и в лечении эрозивноязвенных поражений желудка и пищевода [21, 23, 65]. Перспективы применения ребамипида у пациентов с панкреатитом основываются на данных экспериментальных работ, показавших, что эта молекула оказывает влияние на высвобождение амилазы в ацинарных клетках поджелудочной железы у крыс [66].
Рекомендации по ведению пациентов с COVID-19

Пациентам с ХП в период пандемии следует придерживаться традиционных рекомендаций (самоизоляция, использование дистанционных форм консультаций: телефон, компьютерные технологии - телемедицина, тщательно обоснованное посещение медучреждений).

Многокомпонентное лечение при среднетяжелых и тяжелых формах течения COVID-19 включает этиотропную, патогенетическую, симптоматическую терапию, сопровождающуюся у части пациентов побочными эффектами - тошнотой, рвотой, диарей, болевым абдоминальным синдромом (лопинавир/ритонавир гидроксихлорохин, азитромицин, мефлохин, рибавирин - таблица 5, рекомбинантный интерферон бета-1b, тоцилизумаб таблица 4) [1]. При повышении активности панкреатических ферментов (амилаза, липаза) и/или развитии панкреатита лопинавир/ритонавир необходимо отменить.

Указанные клинические особенности течения и лечения COVID-19 предполагают проведение дифференциальной диагностики с обострением панкреатита с оценкой клинической картины (хронологическая взаимосвязь симптомов - либо с традиционными провоцирующими факторами обострения панкреатита, либо, собственно, с COVID19), а также с использованием в соответствии с клиническими рекомендациями лабораторноинструментального обследования [58-60]. При обострении панкреатита уточняется степень его тяжести: оценивают клиническую симптоматику (кожные проявления - гиперемия, “мраморность", цианоз; проявления энцефалопатии, гипотония АД <100 мм рт.ст., снижение диуреза), лабораторные показатели - содержание лейкоцитов, глюкозы, альбумина, мочевины, кальция, коагулограмму, кислотно-щелочное равновесие [67],

Таблица 5

Побочные эффекты препаратов при лечении COVID-19 [1]

\begin{tabular}{lll}
\hline Препарат & $\begin{array}{l}\text { Побочные эффекты ЖКТ } \\
\text { Часто }\end{array}$ & $\begin{array}{l}\text { Побочные эффекты ЖКТ } \\
\text { Нечасто }\end{array}$ \\
\hline Лопинавир/ритонавир & $\begin{array}{l}\text { Очень часто: тошнота, диарея; } \\
\text { Часто: повышение АСТ, АЛТ, ГГТ, гепатит; } \\
\text { Панкреатит особенно } \\
\text { при гипертриглицеридемии }\end{array}$ & $\begin{array}{l}\text { Стеатоз печени, гепатомегалия, холангит, } \\
\text { ректальные кровотечения, стоматит, язвы } \\
\text { в полости рта, недержание кала, запоры, } \\
\text { сухость во рту }\end{array}$ \\
\hline Гидроксихлорохин, хлорохина фосфат & Тошнота, диарея, рвота, боль животе & Повышение функциональных печеночных \\
& & проб \\
\hline Азитромицин & Тошнота, рвота, боль в животе, диарея & $\begin{array}{l}\text { Анорексия, запор, метеоризм, } \\
\text { псевдомембранозный колит, желтуха, } \\
\text { гепатит }\end{array}$ \\
\hline Мефлохин & & Нарушения функции печени (разной \\
степени выраженности), диспепсия
\end{tabular}

Примечание: АЛТ - аланинаминотрансфераза, АСТ - аспартатаминотрансфераза, ГГТ - гамма-глутамиламинотрансфераза, ЖКТ желудочно-кишечный тракт. 
по показаниям - уточняющие исследования МРТ органов брюшной полости (ЭндоУЗИ). При подтверждении острого панкреатита - продолжение лечения в условиях хирургического стационара.

Лечение обострения ХП проводят в соответствии с современными российскими клиническими рекомендациями [58-60, 63]:

- для купирования болевого синдрома рекомендуется применение диеты, полиферментных препаратов, анальгетиков, спазмолитиков. Проводится лечение полиферментными препаратами: микротаблетки/минимикросферы (25000 Ед во время приема пищи) в сочетании с антисекреторными препаратами (омепразол 20-40 мг/сут., рабепразол 20 мг/сут.). У пациентов с выраженной интенсивностью боли к терапии показано добавление: парацетамола (500 мг до 4 раз/сут.), октреотида (п/к по 100 мг до 3 раз/сут.), в случае необходимости трамадола (табл. 50/100 мкг или внутримышечно 1 мл (50 мкг), 2 мл (100 мкг) в зависимости от интенсивности болевого синдрома);

- для купирования проявлений внешнесекреторной недостаточности рекомендуется соблюдение диетических рекомендаций; назначается заместительная ферментная терапия: микротаблетки и минимикросферы, покрытые кишечнорастворимой оболочкой, более эффективны: рекомендуемая минимальная доза составляет 25000-40000 Ед липазы на основной прием пищи и 10000-25000 Ед липазы - на промежуточный прием пищи, адекват-

\section{Литература/References}

1. Temporary guidelines for Prevention, diagnosis and treatment of new coronavirus infection (COVID-19) version 7 (03.06.2020) of the Ministry of health of the Russian Federation. (In Russ.) Временные методические рекомендации Профилактика, диагностика и лечение новой коронавирусной инфекции (COVID-19) версия 7 (03.06.2020) Министерства здравоохранения Российской Федерации. https://www.rosminzdrav. ru/news/2020/06/03/14109-minzdrav-rossii-utverdil-7-versiyumetodicheskih-rekomendatsiy-po-lecheniyu-covid-19

2. Mao R, Qiu Y, He J-S, et al. Manifestations and prognosis of gastrointestinal and liver involvement in patients with COVID-19: a systematic review and meta-analysis. Lancet Gastroenterol Hepatol. 2020. Published Online May 12, 2020. doi:10.1016/ S2468-1253(20)30126-6.

3. Grinevich VB, Kravchuk, AYu, Tkachenko El, etc. Features of management of patients with gastroenterological pathology in the conditions of the COVID-19 pandemic. Experimental and clinical gastroenterology. 2020;176(4). (In Russ.) Гриневич В. Б., Кравчук Ю. А., Ткаченко Е. И. и др. Особенности ведения больных с гастроэнтерологической патологией в условиях пандемии COVID-19. Экспериментальная и клиническая гастроэнтерология. 2020;176(4). doi:10.31146/1682-8658-ecg-176-4.

4. Ivashkin VT, Sheptulin AA, Zolnikova OY, et al. New coronavirus infection (COVID-19) and digestive system. Russian Journal of Gastroenterology, Hepatology, Coloproctology. 0 (In Russ.) Ивашкин В. Т., Зольникова О. Ю., Охлобыстин А. В. и др. Новая ная доза подбирается индивидуально; повышению эффекта полиферментных препаратов способствует добавление ИПП (омепразола - 20/40 мг/сут., рабепразола - 20 мг/сут.).

Лечение недостаточности эндокринной функции проводится в соответствии с Клиническими Рекомендациями Российской Ассоциации Эндокринологов “Алгоритмы Специализированной Медицинской Помощи больным Сахарным Диабетом”, “Временными рекомендациями по ведению больных COVID19 и эндокринными заболеваниям" медицинской ассоциацией эндокринологов Санкт-Петербурга, 2020г, а также рекомендациями настоящего Консенсуса: Тактика ведения СД дифференцируется в зависимости от степени тяжести COVID-19, сопутствующей полиорганной недостаточности и характера специфической противовирусной терапии [68, 69].

Резюме:
1. Отсутствуют достоверные данные о взаимовлиянии ХП
и COVID-19.
2. Высокая распространенность ХП, тяжесть его течения,
экзо-/эндокринная недостаточность обосновывают необхди-
мость профилактических мероприятий по снижению заболева-
емости и осложненного течения COVID-19 у пациентов с ХП.
3. Направления ведения таких пациентов включают: диспан-
серное наблюдение (диагностика, коррекция лечения, купи-
рование функцинальных нарушений), дифференциальная
диагностика, рассмотрение возможности профилактического
противовирусного лечения для пациентов с трофологической
недостаточностью (гипоальбуминемией) и/или суб-декомпен-
сированным Сд.

коронавирусная инфекция (COVID-19) и система органов пищеварения. Российский журнал гастроэнтерологии, гепатологии, колопроктологии. 2020:doi:10.22416/1382-43762020-30-3-7.

5. Ma C, Cong Y, Zhang H. COVID-19 and the Digestive System. Am J Gastroenterol 2020;00:1-4. doi:10.14309/ajg.0000000000000691.

6. Lin L, Jiang X, Zhang Z, at al. Gastrointestinal Symptoms of 95 Cases With SARS-CoV-2 Infection. Gut. 2020; 69(6):997-1001. doi:10.1136/gutjnl-2020-321013.

7. Pan L, Mu M, Ren HG, et al. Clinical characteristics of COVID-19 patients with digestive symptoms in Hubei, China: a descriptive, cross-sectional, multicenter study. Am J Gastroenterol. 2020. doi:10.14309/ajg.0000000000000620.

8. Cha MH, Regueiro M, Sandhu DS. Gastrointestinal and hepatic manifestations of COVID-19: A comprehensive review. World J Gastroenterol. 2020;26(19):2323-32. doi:10.3748/wjg.v26. i19.2323.

9. Suresh Kumar VC, Mukherjee S, Harne PS, et al. Novelty in the gut: a systematic review and meta-analysis of the gastrointestinal manifestations of COVID-19. BMJ Open Gastroenterol. 2020;7(1): e000417. doi:10.1136/bmjgast-2020-000417.

10. Cheung KS, Hung IF, Chan PP. Gastr ointestinal Manifestations of SARS-CoV-2 Infection and Virus Load in Fecal Samples from the Hong Kong Cohort and Systematic Review and Meta-analysis. Gastroenterology. 2020:S0016-5085(20)30448-0. doi:10.1053/j. gastro.2020.03.065 
11. Sultan S, Altayar O, Siddique SM. AGA Institute Rapid Review of the Gastrointestinal and Liver Manifestations of COVID-19, Meta-Analysis of International Data, and Recommendations for the Consultative Management of Patients with COVID-19. Gastroenterology. 2020:S0016-5085(20)30593-X. doi:10.1053/j. gastro.2020.05.001.

12. Parasa S, Desai M, Thoguluva Chandrasekar V, et al. Prevalence of Gastrointestinal Symptoms and Fecal Viral Shedding in Patients With Coronavirus Disease 2019: A Systematic Review and Metaanalysis. JAMA Netw Open. — 2020;3(6):e2011335. doi:10.1001/ jamanetworkopen.2020.11335.

13. Fasano A. All disease begins in the (leaky) gut: role of zonulinmediated gut permeability in the pathogenesis of some chronic inflammatory diseases. F1000Res. 2020;9:F1000 Faculty Rev-69. Published 2020 Jan 31.

14. Matysiak-Budnik T, Heyman M, Mégraud F. Review article: rebamipide and the digestive epithelial barrier. Aliment Pharmacol Ther. 2003;18 (Suppl. 1):55-62. doi:10.1046/j.1365-2036.18.s1.6.x.

15. Shim S, Jang HS, Myung HW, et al. Rebamipide ameliorates radiation-induced intestinal injury in a mouse model. Toxicol Appl Pharmacol. 2017;15,329:40-7. doi:10.1016/j.taap.2017.05.012.

16. Jaafar MH, Safi SZ, Tan MP, et al. Efficacy of Rebamipide in Organic and Functional Dyspepsia: A Systematic Review and Meta-Analysis. Dig Dis Sci. 2018;63(5):1250-60. doi:10.1007/ s10620-017-4871-9.

17. Lazebnik LB, Tkachenko El, Abdulganieva DI, et al. VI National recommendations for the diagnosis and treatment of aciddependent and associated with Helicobacter Pylori diseases (VI Moscow agreements). Experimental and clinical gastroenterology. 2017;2:3-21. (In Russ.) Лазебник Л.Б., Ткаченко Е. И., Абдулганиева Д.И и др. VI Национальные рекомендации по диагностике и лечению кислотозависимых и ассоциированных с Helicobacter Pylori заболеваний (VI Московские соглашения). Экспериментальная и клиническая гастроэнтерология. 2017;2:3-21.

18. Ivashkin VT, Mayev IV, Lapina TL, et al. Diagnostics and treatment of Helicobacter pylori infection in adults: Clinical guidelines of the Russian gastroenterological association. Russian Journal of Gastroenterology, Hepatology, Coloproctology. 2018;28(1):5570. (In Russ.) Ивашкин В.Т., Маев И.В., Лапина Т.Л. и др. Клинические рекомендации Российской гастроэнтерологической ассоциации по диагностике и лечению инфекции Helicobacter pylori у взрослых. Российский журнал гастроэнтерологии, гепатологии, колопроктологии. 2018;28(1):5570. doi:10.22416/1382-4376-2018-28-1-55-70.

19. Karateev $A E$, Nasonov EL, Ivashkin VT, et al. Rational use of non-steroidal anti-inflammatory drugs. Clinical recommendations. Scientific and practical rheumatology. 2018;56:1-29. (In Russ.) Каратеев А. Е., Насонов Е. Л., Ивашкин В. Т. и др. Рациональное использование нестероидных противовоспалительных препаратов. Клинические рекомендации. Научно-практическая ревматология. 2018;56:1-29.

20. Lazebnik LB, Golovanova EV, Alekseenko SA, et al. Recommendations for the prevention and treatment of esophago-gastro-enterocolopathies induced by non-steroidal anti-inflammatory drugs. Experimental and clinical gastroenterology. 2018;151(03):4-18 (In Russ.) Лазебник Л.Б., Голованова Е.В., Алексеенко С.А. и др. Рекомендации по профилактике и лечению эзофагогастро-энтеро-колопатий, индуцированных нестероидными противовоспалительными препаратами. Экспериментальная и клиническая гастроэнтерология. 2018;151(03):4-18.

21. Ivashkin VT, Maev IV, Tsar'kov PV, et al. Diagnosis and Treatment of Peptic Ulcer in Adults (Clinical Guidelines of the Russian
Gastroenterological Association, Russian Society of Colorectal Surgeons and the Russian Endoscopic Society). Russian Journal of Gastroenterology, Hepatology, Coloproctology. 2020;30(1):4970. (In Russ.) Ивашкин В.Т., Маев И.В., Царьков П.В. и др. Диагностика и лечение язвенной болезни у взрослых (Клинические рекомендации Российской гастроэнтерологической ассоциации, Российского общества колоректальных хирургов и Российского эндоскопического общества). Российский журнал гастроэнтерологии, гепатологии, колопроктологии. 2020;30(1):49-70. doi:10.22416/1382-4376-202030-1-49-70.

22. Oganov RG, Simanenkov VI, Bakulin IG, et al. Comorbidities in clinical practice. Algorithms for diagnostics and treatment. Cardiovascular Therapy and Prevention. 2019;18(1):5-66. (In Russ.) Оганов Р.Г., Симаненков В.И., Бакулин И.Г., и др. Коморбидная патология в клинической практике. Алгоритмы диагностики и лечения. Кардиоваскулярная терапия и профилактика. 2019;18(1):5-66. doi:10.15829/1728-8800-2019-1-5-66.

23. Wen $X$, Chen $X$, Zhou X. Rebamipide inhibited expression of TLR4 and TNF-alpha release in pulmonary epithelial cell line A549 induced by lipopolysaccharide. Zhong Nan Da Xue Xue Bao Yi Xue Ban. 2009;34(5):457-60.

24. Yasuda T, Chiba H, Satomi T, et al. Preventive effect of rebamipide gargle on chemoradiotherpy-induced oral mucositis in patients with oral cancer: a pilot study. J Oral Maxillofac Res. 2012;2(4):e3. Published 2012 Jan 1. doi:10.5037/jomr.2011.2403.

25. Akagi S, Fujiwara $\mathrm{T}$, Nishida $\mathrm{M}$, et al. The effectiveness of rebamipide mouthwash therapy for radiotherapy and chemoradiotherapyinduced oral mucositis in patients with head and neck cancer: a systematic review and meta-analysis. J Pharm Health Care Sci. 2019;5:16. Published 2019 Jul 25. doi:10.1186/s40780-019-0146-2.

26. Urita $Y$, Watanabe $T$, Maeda $T$, et al. Rebamipide and mosapride enhance pilocarpine-induced salivation. N Am J Med Sci. 2009;1(3):121-4.

27. Ivashkin VT, Mayev IV, Trukhmanov AS, et al. Diagnostics and treatment of gastroesophageal reflux disease: clinical guidelines of the Russian gastroenterological association. Russian Journal of Gastroenterology, Hepatology, Coloproctology. 2017;27(4):7595. (In Russ.) Ивашкин В.Т., Маев И.В., Трухманов А.С. и др. Клинические рекомендации Российской гастроэнтерологической ассоциации по диагностике и лечению гастроэзофагеальной рефлюксной болезни. Российский журнал гастроэнтерологии, гепатологии, колопроктологии. 2017;27(4):7595. doi:10.22416/1382-4376-2017-27-4-75-95.

28. Song TJ, Kim J. Risk of post-stroke pneumonia with proton pump inhibitors, $\mathrm{H} 2$ receptor antagonists and mucoprotective agents: A retrospective nationwide cohort study. PLoS One. 2019;14(5):e0216750. doi:10.1371/journal.pone.0216750.

29. Zhou J, Li C, Zhao G, et al. Human intestinal tract serves as an alternative infection route for Middle East respiratory syndrome coronavirus. Sci Adv. 2017;3(11): eaao4966. doi:10.1126/sciadv. aao4966.

30. Martynov Al, Sheptulin AA, Mayev IV, et al. New Prospects of Cytoprotection in the Treatment and Prevention of Gastric and Intestinal Diseases (Resolution of an Expert Council and Literature Review). Russian Journal of Gastroenterology, Hepatology, Coloproctology. 2020;30(2):7-14. (In Russ.) Мартынов А.И., Шептулин А.А., Маев И.В. и др. Новые возможности цитопротекции в лечении и профилактике заболеваний желудка и кишечника (резолюция Экспертного совета и обзор литературы). Российский журнал гастроэнтерологии, гепатологии, колопроктологии. 2020;30(2):7-14. doi:10.22416/1382-43762020-30-2-7-14. 
31. Zhou F, Yu T, Du R, et al. Clinical course and risk factors for mortality of adult inpatients with COVID-19 in Wuhan, China: a retrospective cohort study [published correction appears in Lancet. 2020 Mar 28;395(10229):1038] [published correction appears in Lancet. 2020 Mar 28;395(10229):1038]. Lancet. 2020;395(10229):10541062. doi:10.1016/S0140-6736(20)30566-3.

32. Moon AM, Webb GJ, Aloman C, et al. High mortality rates for SARS-CoV-2 infection in patients with pre-existing chronic liver disease and cirrhosis: Preliminary results from an international registry [published online ahead of print, 2020 May 21]. J Hepatol. 2020;S0168-8278(20)30305-6. doi:10.1016/j.jhep.2020.05.013.

33. Walls AC, Park Y-J, Tortorici MA, at al. Structure, Function, and Antigenicity of the SARS-CoV-2 Spike Glycoprotein. Cell. 2020;181,2;281-92.

34. Paizis G, Tikellis C, Cooper ME, et al. Chronic liver injury in rats and humans upregulates the novel enzyme angiotensin converting enzyme 2. Gut. 2005;54(12):1790-6. doi:10.1136/ gut.2004.062398.

35. Xu Z, Shi L, Wang Y, et al. Pathological findings of COVID-19 associated with acute respiratory distress syndrome. The Lancet Respiratory Medicine. 2020;8,4:420-2. doi:10.1016/S22132600(20)30076-X.

36. Gu J, Han B, Wang J. COVID-19: Gastrointestinal manifestations and potential fecal-oral transmission. Gastroenterology. 2020;158(6):1518-9. doi:10.1053/j.gastro.2020.02.054.

37. Gao F, Zheng KI, Wang XB, et al. Metabolic associated fatty liver disease increases coronavirus disease 2019 disease severity in nondiabetic patients [published online ahead of print, 2020 May 21]. J Gastroenterol Hepatol. 2020;10.1111/jgh.15112. doi:10.1111/jgh.15112.

38. Mayevskaya M. V., Nadinskaia M. Y., Lunkov V. D., et al. An Effect of Ursodeoxycholic Acid on Inflammation, Steatosis and Liver Fibrosis and Atherogenesis Factors in Patients with Non-Alcoholic Fatty Liver Disease: Results of the USPEH Study. Russian Journal of Gastroenterology, Hepatology, Coloproctology. 2019;29(6):2229. (In Russ.) Маевская М.В., Надинская М. Ю., Луньков В.Д. и др. Влияние урсодезоксихолевой кислоты на воспаление, стеатоз и фиброз печени и факторы атерогенеза у больных неалкогольной жировой болезнью печени: результаты исследования УСПЕХ. Российский журнал гастроэнтерологии, гепатологии, колопроктологии. 2019;(6):22-9. doi: 10.22416/13824376-2019-29-6-22-29.

39. Al-Ani AH, Prentice RE, Rentsch $\mathrm{CA}$, et al. Review article: prevention, diagnosis and management of COVID-19 in the IBD patient. Aliment Pharmacol Ther. 2020:10.1111/apt.15779. doi:10.1111/apt.15779.

40. Current Data | Secure-IBD Database. https://covidibd.org/ current-data/. Accessed June, 02, 2020

41. Ivashkin VT, Shelygin YuA, Khalif IL, et al. Clinical Guidelines of the Russian Gastroenterological Association and the Association of Coloproctologists of Russia for the diagnosis and treatment of ulcerative colitis. Coloproctology. 2017;1:6-30. (In Russ.) Ивашкин В.Т., Шелыгин Ю.А., Халиф И. Л., и др. Клинические рекомендации Российской Гастроэнтерологической Ассоциации и Ассоциации Колопроктологов России по диагностике и лечению язвенного колита. Колопроктология. 2017;1:6-30.

42. Ivashkin VT, Shelygin YuA, Khalif IL, et al. Clinical Guidelines of the Russian Gastroenterological Association and the Association of Coloproctologists of Russia for the diagnosis and treatment of Crohn's disease. Coloproctology. 2017;2:7-29. (In Russ.) Ивашкин В.Т., Шелыгин Ю.А., Халиф И.Л., и др. Клинические рекомендации Российской Гастроэнтерологической
Ассоциации и Ассоциации Колопроктологов России по диагностике и лечению болезни Крона. Колопроктология. 2017;2:7-29.

43. Samanta J, Dhar J, Khaliq A, Kochhar R. 2019 Novel Coronavirus Infection: Gastrointestinal Manifestations. Journal of Digestive Endoscopy. 2020;11(01):13-8. doi:10.1055/s-0040-1712077.

44. Gastroenterology professional society guidance on endoscopic procedures during the COVID-19 pandemic American Gastroenterological Association. https://gastro.org/practiceguidance/practice-updates/covid-19/gastroenterologyprofessional-society-guidance-on-endoscopic-proceduresduring-the-covid-19-pandemic/ Accessed June 06, 2020.

45. Kennedy NA, Jones GR, Lamb CA, et al. British Society of Gastroenterology guidance for management of inflammatory bowel disease during the COVID-19 pandemic. Gut. 2020;69(6):984-90. doi:10.1136/gutjnl-2020-321244.

46. Muhametova DD, Abdulganieva DI, Koshkin SA, et al. Assessment of intestinal permeability in patients with inflammatory bowel diseases is a Medical matter. 2016;1:46-51. (In Russ.) Мухаметова Д.Д., Абдулганиева Д.И., Кошкин С.А., и др. Оценка кишечной проницаемости у пациентов с воспалительными заболеваниями кишечника. Лечебное дело. 2016;1:46-51.

47. Rubin DT, Abreu MT, RaiV, on behalf of the International Organization for the Study of Inflammatory Bowel Disease. Management of Patients with Crohn's Disease and Ulcerative Colitis During the COVID-19 Pandemic: Results of an International Meeting. Gastroenterology. 2020; doi:10.1053/j.gastro.2020.04.002.

48. Bezzio C, Saibeni S, Variola A, et al Outcomes of COVID-19 in 79 patients with IBD in Italy: an IG-IBD study. Gut. 2020. doi:10.1136/ gutjnl-2020-321411.

49. RAND PANEL STATEMENTS Patients with COVID-19 Crohn's Disease and COVID-19 Ulcerative Colitis. IOIBD Update on COVID19 for Patients with Crohn's Disease and Ulcerative Colitis. https://ioibd.org/wp-content/uploads/2020/05/RAND-PANELSTATEMENTS.pdf

50. Rubin DT, Feuerstein JD, Wang AY, Cohen RD. AGA Clinical Practice Update on Management of Inflammatory Bowel Disease During the COVID-19 Pandemic: Expert Commentary. Gastroenterology. 2020. doi:10.1053/j.gastro.2020.04.012.

51. Ivashkin VT, Shelygin YA, Baranskaya YK, et al. Diagnosis and treatment of the irritable bowel syndrome: clinical guidelines of the Russian gastroenterological association and Russian association of coloproctology. Russian Journal of Gastroenterology, Hepatology, Coloproctology. 2017;27(5):76-93. (In Russ.) Ивашкин В.T., Шелыгин Ю.А., Баранская Е.К., и др. Клинические рекомендации Российской гастроэнтерологической ассоциации и Ассоциации колопроктологов России по диагностике и лечению синдрома раздраженного кишечника. Российский журнал гастроэнтерологии, гепатологии, колопроктологии. 2017;27(5):76-93. doi:10.22416/1382-4376-2017-27-5-76-93.

52. Wang $\mathrm{C}$, Pan R, Wan $\mathrm{X}$, et al. Immediate Psychological Responses and Associated Factors during the Initial Stage of the 2019 Coronavirus Disease (COVID-19) Epidemic among the General Population in China. Int $\mathrm{J}$ Environ Res Public Health. 2020;17(5):1729. doi:10.3390/ijerph17051729.

53. Harmer D, Gilbert M, Borman R, Clark K. L. Quantitative mRNA expression profi ling of ACE2, a novel homologue of angiotensin converting enzyme. FEBS Lett. 2020;532:107-10.

54. Naito Y, Yoshikawa T. Rebamipide: a gastrointestinal protective drug with pleiotropic activities. Expert Rev Gastroenterol Hepatol. 2010;4(3):261-70. doi:10.1586/egh.10.25.38-41.

55. Gao QY, Chen YX, Fang JY. 2019 Novel coronavirus infection and gastrointestinal tract. J Dig Dis. 2020;21(3):125-6. doi:10.1111/1751-2980.12851. 
56. Szatmary P, Arora A, Raraty MGT, et al. Emerging phenotype of SARS-CoV2 associated pancreatitis. Gastroenterology. 2020. doi:10.1053/j.gastro.2020.05.069.

57. Bruno G, Fabrizio C, Santoro CR, Buccoliero GB. Pancreatic injury in the course of coronavirus disease 2019 (COVID-19): a not-sorare occurrence [published online ahead of print, 2020 Jun 4]. J Med Virol. 2020;10.1002/jmv.26134. doi:10.1002/jmv.26134.

58. Clinical Recommendations of the Russian Gastroenterological Association for the diagnosis and treatment of chronic pancreatitis. Ed. Ivashkin VT, Maev IV, Shifrin OS, et al. 2014. 45 p. (In Russ.) Клинические Рекомендации Российской Гастроэнтерологической Ассоциации по диагностике и лечению хронического панкреатита. Под ред. Ивашкина В.Т., Маева И. В., Шифрина О. С. и др. М.,2014. 45 с.

59. Guidelines Of the scientific society of Gastroenterologists on the diagnosis and treatment of chronic pancreatitis (adopted by the II Congress of the NOGR on March 2, 2011 at a meeting of the Russian pancreatological club. Experimental and clinical medicine. 2011;7:122-9. (In Russ.) Рекомендации Научного Общества Гастроэнтерологов по диагностике и лечению хронического панкреатита (приняты II съездом НОГР 2 марта 2011 на заседании Российского панкреатологического клуба. Экспериментальная и клиническая медицина. 2011;7:122-9.

60. Khatkov IE, Maev IV, Bordin DS, et al. Russian consensus on the diagnosis and treatment of chronic pancreatitis. Therapeutic archive. 2017;2:105-13. (In Russ.) Хатьков И. Е. Маев И. В., Бордин Д.С., и др. Российский консенсус по диагностике и лечению хронического панкреатита. Терапевтический архив. 2017;2:105-13. doi:10.17116/terarkh 2017892105-113.

61. Khatkov IE, Maev IV, Bordin DS, et al. Russian consensus on the diagnosis and treatment of chronic pancreatitis: emphasis on nutritional status and nutrition issues. Pharmateca. 2016; Gastroenterology/Hepatology: 27-32. (In Russ.) Хатьков И.Е. Маев И. В., Бордин Д. С., и др. Российский консенсус по диагностике и лечению хронического панкреатита: акцент на нутритивный статус и вопросы питания. Фарматека. 2016; Гастроэнтерология/гепатология:27-32.

62. Khatkov IE, Maev IV, Bordin DS, et al. Controversial issues of the Russian consensus on the diagnosis and treatment of chronic pancreatitis. Almanac of clinical medicine. 2016;44,6:654-60. (In Russ.) Хатьков И.Е. Маев И.В., Бордин Д.С., и др. Спорные вопросы российского консенсуса по диагностике и лечению хронического панкреатита. Альманах клинической медицины. 2016;44,6:654-60.

63. Ivashkin VT, Mayev IV, Okhlobystin AV, et al. Clinical Guidelines of the Russian gastroenterological Association for the diagnosis and treatment of exocrine pancreatic insufficiency. Russian Journal of Gastroenterology, Hepatology, Coloproctology. 2018;28(2):72100. (In Russ.) Ивашкин В.Т., Маев И.В., Охлобыстин А.В. и др. Клинические рекомендации Российской гастроэнтерологической ассоциации по диагностике и лечению экзокринной недостаточности поджелудочной железы. Российский журнал гастроэнтерологии, гепатологии, колопроктологии. 2018;28(2):72-100.

64. Hong SJ, Park S-H, Moon JS, et al. Benefits of Combination Therapy with Esomeprazole and Rebamipide in Symptom Improvement in Reflux Esophagitis: An International Multicenter Study. Gut Liver. 2016;10(6):910-6. doi: 10.5009/gnl15537.

65. Yoshida N, Kamada K, Tomatsuri N, et al. Management of recurrence of symptoms of gastroesophageal reflux disease: synergistic effect of rebamipide with $15 \mathrm{mg}$ lansoprazole. Digestive diseases and sciences. 2010;55(12):3393-8. doi: 10.1007/s10620-010-1166-9.

66. Moon SJ, An JM, Kim J, et al. Pharmacological characterization of rebamipide: its cholecystokinin CCK1 receptor binding profile and effects on $\mathrm{Ca} 2+$ mobilization and amylase release in rat pancreatic acinar cells. Eur J Pharmacol. 2004;505(1-3):61-6. doi:10.1016/j. ejphar.2004.10.032.

67. Clinical Guidelines of the Russian society of Surgeons, Association of hepatopancreatobiliary surgeons of the CIS countries. Acute pancreatitis. Moscow, 2015. 38 р. (In Russ.) Клинические Рекомендации Российского Общества Хирургов, Ассоциации гепатопанкреатобилиарных хирургов стран СНГ. Острый панкреатит. М., 2015. $38 \mathrm{c.}$

68. Clinical Guidelines Of The Russian Association Of Endocrinologists. Algorithms for Specialized Medical Care for patients with Diabetes. Ed. Dedov II, Shestakova MV, Mirova AYu. M. 2017. 111 p. (In Russ.) Клинические Рекомендации Российской Ассоциации Эндокринологов. Алгоритмы Специализированной Медицинской Помощи больным Сахарным Диабетом. Под ред. Дедова И.И., Шестаковой М.В., Майрова А. Ю. М., $2017.111 \mathrm{c}$.

69. Temporary Guidelines for the management of patients with COVID19 and endocrine diseases. Ed. Grineva EN, Khalimov YS, Babenko AYu, et al. Medical Association of Endocrinologists of Saint-Petersburg. 2020, 9 р. (In Russ.) Временные рекомендации по ведению больных COVID19 и эндокринными заболеваниями. Под ред. Гринева Е. Н., Халимова Ю.Ш., Бабенко А. Ю. и др. Медицинская Ассоциациея Эндокринологов СанктПетербурга, 2020. 9 c. 